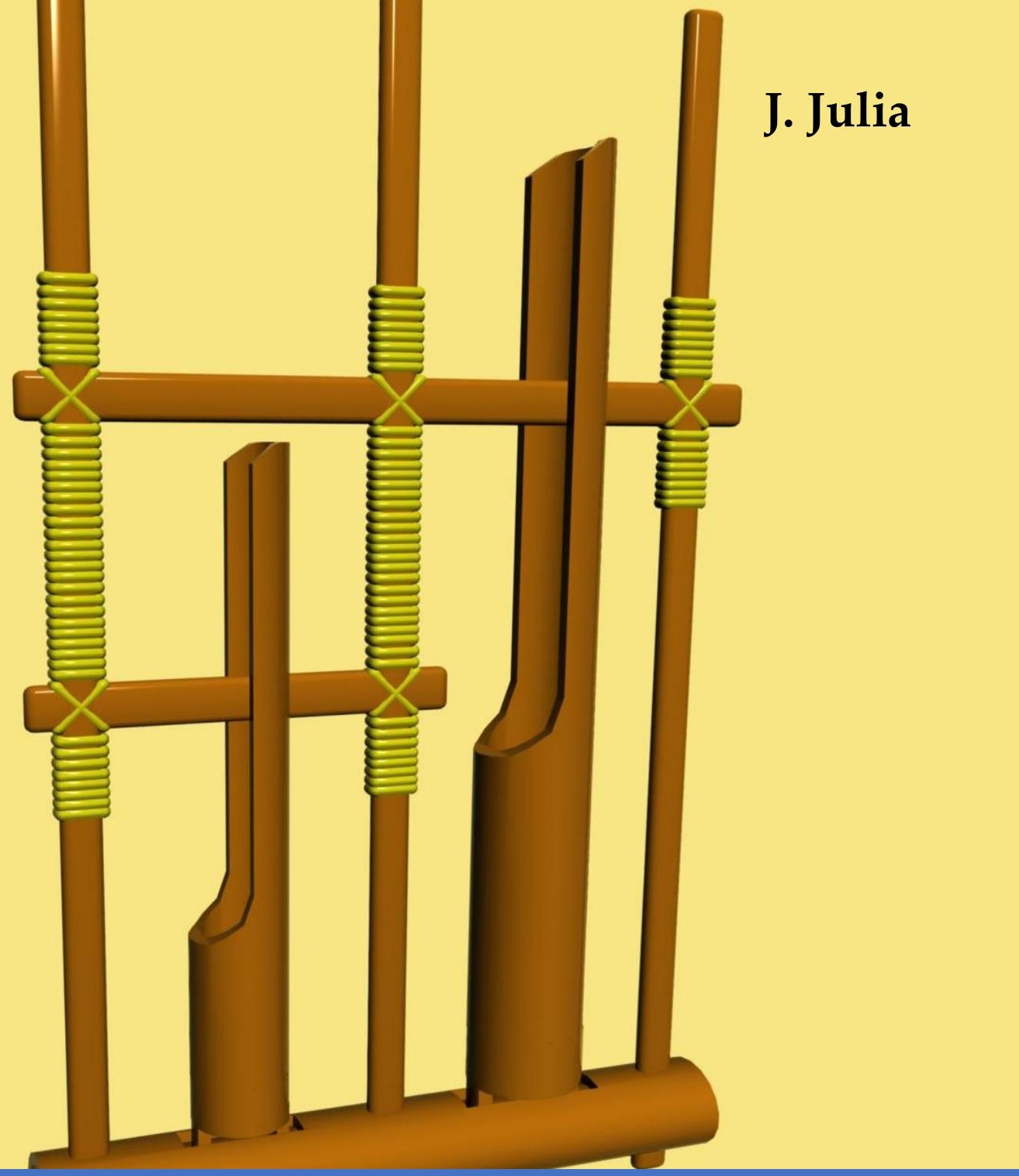

\title{
Pendidikan Musik: Permasalahan dan Pembelajarannya
}




\title{
Pendidikan Musik: \\ Permasalahan dan Pembelajarannya
}

\author{
J. Julia
}

How to Cite:

Julia, J. (2017). Pendidikan Musik: Permasalahan dan Pembelajarannya. Sumedang: UPI Sumedang Press. 
Blank Page 


\title{
Pendidikan Musik: \\ Permasalahan dan Pembelajarannya
}

\author{
J. Julia \\ PGSD Universitas Pendidikan Indonesia \\ Kampus Sumedang
}

UPI Sumedang Press 
100 halaman $+x, 15,5 \times 23 \mathrm{~cm}$

ISBN: 978-979-3786-38-4

elSBN: 978-602-6438-05-8

Judul:

Pendidikan Musik: Permasalahan dan Pembelajarannya

Penulis:

J. Julia

Editor:

Prana Dwija lswara

Tata Letak \& Sampul:

D. Abrian Prabowo

Cetakan:

Kesatu, Agustus 2014

Kedua, Mei 2017

\section{Diterbitkan oleh:}

UPI Sumedang Press

Jl. Mayor Abdurachman No. 211 Sumedang

Kutipan Pasal 44, Ayat 1 dan 2, Undang-Undang Republik Indonesia tentang HAK CIPTA. Tentang Sanksi Pelanggaran Undang-Undang Nomor 19 Tahun 2002 tentang HAK CIPTA, sebagaimana telah diubah dengan Undang-Undang No.7 Tahun 1987 jo, Undang-Undang No. 12 Tahun 1997, bahwa:

1. Barangsiapa dengan sengaja dan tanpa hak mengumumkan atau menyebarkan suatu ciptaan sebagaimana dimaksud dalam pasal 2 ayat (1) dan ayat (2) dipidana dengan pidana penjara masing-masing paling singkat 1 (satu) bulan dan atau denda paling sedikit Rp. 1.000.000,00 (satu juta rupiah), atau pidana penjara paling lama 7 (tujuh) tahun dan atau denda paling banyak Rp. 5.000.000.000,00 (lima miliar rupiah).

2. Barangsiapa dengan sengaja menyiarkan, mengedarkan, atau menjual kepada umum suatu ciptaan barang hasil pelanggaran Hak Cipta atau Hak Terkait sebagaimana dimaksud pada ayat (1) dipidana dengan pidana penjara paling lama 5 (lima) tahun dan atau denda paling banyak Rp. 500.000.000,00 (lima ratus juta rupiah). 


\section{Mukadimal}

Segala puji bagi Allah Swt, yang telah memberikan rahmat dan hidayahnya, sehingga sampai saat ini penulis masih dapat dengan istiqomah mengamalkan ilmu-ilmu yang pada hakikatnya berasal dari-Nya. Solawat serta salam semoga selalu dilimpahkan kepada Rosul akhir zaman, yakni Baginda Nabi Muhammad Saw.

Buku yang hadir ke hadapan pembaca yang budiman ini, bukanlah kitab yang mampu mencerahkan semua orang yang haus akan keilmuan (seni), buku ini melainkan hanya sebatas rekam jejak dari seorang penggiat pendidikan seni (musik) yang tengah berjuang demi tegaknya pendidikan seni yang sebenar-benarnya. Maka dari itu, sebagian dari isi buku ini adalah makalah yang sudah disajikan dalam seminar baik tingkat nasional maupun internasional, yang dalam perjalanannya penulis berupaya untuk menyikapi persoalan jagat pendidikan seni sesuai dengan isu dan topik yang dimunculkan dalam seminar. Yang tentunya dianggap sebagai isu aktual pada saat itu. Ada yang berupa gagasan-gagasan konseptual, ada juga tulisan hasil penelitian. Sebagian lagi adalah tulisan-tulisan yang masih berceceran sebagai hasil orat-oret penulis di waktu senggang.

Dan kita tahu, bahwa pendidikan seni di negara kita masih "dinomorduakan", bahkan sepertinya ada kesan belum dianggap sebagai bagian dari ilmu pengetahuan. Itulah tantangan kita, untuk menghadapi puspa ragam persoalan yang senantiasa menampar dunia pendidikan seni kita. Seperti menghadapi kalangan yang belum mampu melihat pendidikan seni sebagai sebuah keajaiban bagi manusia. Padahal melalui senilah manusia bisa mengasah jiwa, dan melalui senilah manusia belajar merasa. Pendidikan seni secara luas bukanlah hanya sebuah jalan menuju alam kesenimanan, melainkan lebih penting dari itu adalah sebuah proses untuk memanusiakan manusia. 
Maka dari itu, seirama dengan topik yang dibahas, buku ini lebih cocok apabila dikonsumsi oleh para mahasiswa, setidaknya mahasiswa jurusan pendidikan seni dan mahasiswa jurusan pendidikan guru sekolah dasar. Namun demikian, tidaklah menjadi batasan apabila buku ini pun senantiasa dibaca oleh berbagai kalangan yang sama-sama memiliki kepedulian terhadap pendidikan seni di Indonesia.

Tidak lupa penulis mengucapkan terima kasih kepada Ketua Prodi PGSD Kelas UPI Kampus Sumedang, yakni lbu Riana lrawati, M.Si, yang telah membantu melalui program-programnya untuk menerbitkan buku-buku karangan dosen di sana agar dipublikasikan secara lebih luas. Ucapan terima kasih pun penulis haturkan kepada mahasiswa tingkat akhir, yaitu Daka Abrian, yang telah meluangkan waktunya untuk membuatkan cover buku yang menawan ini. Teristimewa, penulis merasa bangga dan ucapkan hatur nuhun kepada gerombolan UKM Seni lokahyang UPI Kampus Sumedang, Angkatan Batara Guru dll, yakni Asep Brother and the gang (Hemas, Rani, Derin, Dini, Dhea, Riska, dkk). Yang selalu setia untuk menghidupkan ruh kesenian di kampus tercinta, sehingga terus menginspirasi penulis untuk terus berkarya. Semoga kalian menjadi ikon semangat kultural dari mahasiswa yang hidup di zaman serba multikultur ini.

Terakhir, penulis mengucapkan terima kasih kepada semua pihak yang telah membantu demi terlaksananya penerbitan buku ini. Semoga kebaikan semuanya dibalas oleh Allah Swt, dan diberikan kemudahan dalam segala urusan. Amin.

Buku ini dipersembahkan untuk istriku tercinta, yaitu Rita Aritani, yang sama-sama sedang tholabul 'ilmi, dan anakku tersayang, Mahardika A. Kartawinata, yang selalu menuai kerinduan di hati penulis.

Semarang, tempat pertapaan, 20 Mei 2014

Julia, M.Pd 


\section{Daftarlsi}

Mukadimah $\sim$ v

Daftar lsi vii

\section{Bab 1}

Manusia dan Musik ... (1)

Menilai Musik ... (2)

Perilaku Musikal ... (4)

Daftar Pustaka ... (6)

\section{Bab 2}

Musik pada Diri Manusia ... (8)

Potensi Musikal Individu ... (8)

Perkenalan dengan Musik ... (9)

Perkembangan Musikal Individu ... (10)

Daftar Pustaka ... (12)

\section{Bab 3}

Pendidikan Musik dalam Cengkeraman Kapitalisme ... (13)

Pendahuluan ... (13)

Landasan Teori (15)

Pembahasan ... (16)

Kapitalisme Pendidikan ... (16)

Kapitalisme dalam Pendidikan Musik ... (18)

Solusi Pendidikan Musik ... (21)

Kesimpulan ... (22)

Daftar Pustaka ... (23)

\section{Bab 4}

Strategi Membangun Kompetensi Profesional Guru Musik Sekolah

Dasar ... (24)

Latarbelakang Masalah ... (24) 
Kompetensi Profesional ... (26)

Pembahasan ... (27)

Pendidikan dan Kompetensi Guru Musik Sekolah Dasar ... (28)

Kesimpulan ... (34)

Daftar Pustaka ... (35)

\section{Bab 5}

Strategi Pendidikan Musik: Tanamkan Kemampuan Berpikir Kritis ... (38)

Pendahuluan ... (38)

Berpikir Kritis dalam Musik ... (40)

Strategi Pendidikan Musik ... (43)

Simpulan ... (48)

Referensi ... (49)

\section{Bab 6}

Membangun Kerjasama Kelompok Melalui Ensemble Angklung pada Mahasiswa PGSD ... (51)

Pendahuluan ... (51)

Metode Penelitian ... (53)

Hasil dan Pembahasan ... (54)

Kesimpulan ... (61)

Daftar Pustaka ... (62)

\section{Bab 7}

Penerapan Nilai-Nilai Kearifan Lokal Melalui Penciptaan Lirik Lagu dengan Menggunakan Patokan Sekar Irama Tandak Pupuh Sunda ... (63)

Pendahuluan ... (63)

Konteks Teoretis ... (65)

Metode Penelitian ... (68)

Pembahasan ... (68)

Kesimpulan ... (72)

Daftar Pustaka ... (73) 


\section{Bab 8}

Pendidikan Musik di Sekolah Dasar (Menuju Implementasi

Kurikulum 2013) ... (75)

Pendahuluan ... (75)

Realitas Guru Musik di Sekolah Dasar ... (75)

Potensi Musik pada Anak Sekolah Dasar ... (77)

Tipe Guru Musik di Sekolah Dasar ... (79)

Kebutuhan Pendidikan Musik dalam Kurikulum 2013 ... (81)

Alternatif Mengajar Musik di Sekolah Dasar ... (84)

Kesimpulan ... (85)

Referensi ... (86)

\section{Bab 9}

Sebuah Refleksi Pendidikan Musik ... (87)

Pengajar ... (89)

Sistem Pendidikan ... (93)

Masyarakat ... (94)

Menuju Peningkatan Kualitas Pendidikan Seni ... (96)

Pustaka Rujukan ... (98)

Sumber Tulisan ... (99)

Sekelumit Tentang Penulis ... (100) 
$\sim \mathrm{X} \sim$ 


\section{Bab 1}

\section{OICanusia dAN Musik}

Berbicara ihwal musik, merupakan suatu persoalan yang cukup kompleks, karena musik dapat dikaji dan diinterpretasi dari pelbagai sudut pandang. Seperti mazhab revalationism yang memercayai bahwa musik berasal dan bersumber dari alam metafisika melalui tersibaknya tabir (draw back the veil) atau pewahyuan, dan mazhab naturalism yang memercayai bahwa manusia melalui fitrahnya dapat menciptakan musik (Muhaya, 2003). Oleh karena itu, dalam perkembangannya pun ada yang memandang musik sebagai sesuatu yang sakral, ada juga yang memandang musik sebagai sesuatu yang profan. Salah satunya Beethoven, yang mengatakan bahwa musik adalah mediator antara kehidupan indera dan kehidupan ruh (Rose \& Nicholl, 2006).

Pada umumnya, musik dipandang sebagai segala sesuatu yang berhubungan dengan vokal dan instrumen. Yang dengan perpaduan di antara keduanya dapat menghasilkan sebuah komposisi musikal, sebagaimana yang sering kita sebut sebagai musik vokal. Dalam musik vokal, komposisi musik yang dihasilkan merupakan sebagai hasil pengolahan terhadap unsur-unsur musik seperti ritmik, tempo atau irama, durasi, interval nada, harmonisasi, dan lain-lain. Berbagai aliran atau genre musik seperti Pop, Rock, Jazz, Tembang Sunda Cianjuran, Kawih Degung, Kiliningan, Musik Kontemporer, dan lain-lain, dapat dirasakan perbedaannya karena adanya pengolahan terhadap unsur-unsur musik tersebut serta perbedaan jenis instrumen yang digunakan.

Merriam menyatakan, bahwa bunyi musik adalah hasil proses perilaku manusia yang dibentuk oleh nilai, sikap, dan kepercayaan orang-orang sebagai anggota suatu kebudayaan tertentu (Hermawan, 2002:84). Artinya bunyi musik dipengaruhi oleh 
berbagai hal yang terkait dengan adat dan budaya tertentu. Seperti musik di Sunda atau lazim disebut sebagai karawitan Sunda, karena Sunda memiliki latarbelakang kehidupannya sebagai masyarakat agraris, kesenian diciptakan dan digunakan untuk melengkapi upacara yang berkaitan dengan kegiatan pertanian (Sasaki, 2007:4). Oleh sebab itu, musik yang digunakan pun tidak jauh dari adat dan budaya yang ada di masyarakat Sunda.

\section{Menilai Musik}

Dengan memerhatikan uraian di atas, maka tak heran jika banyak masyarakat yang memandang dan mengambil inferensi, bahwa musik adalah segala sesuatu yang hanya berhubungan dengan bunyi-bunyian dari instrumen musik dan vokalis. Oleh sebab itu, apa yang tersaji seperti dalam tayangan televisi, yakni musik dangdut, pop Sunda, Rock, dan sebagainya, itulah musik. Keluar dari acara dan suasana tersebut bukanlah peristiwa musikal. Sehingga jika ada yang melihat dari kacamata tertentu musik dapat dianggap sebagai sesuatu yang hanya dapat menimbulkan kenikmatan sesaat dan kurang bernilai.

Tidak sedikit masyarakat atau kalangan tertentu yang menilai negatif terhadap musik. Musik yang notabene telah memiliki banyak fungsi, menjadi sesuatu yang kurang berfungsi apalagi bermanfaat. Hal ini terjadi karena kita terlena dengan ikon musik yang senantiasa hanya berkaitan dengan urusan bunyi-bunyian dan performen pemainnya, sehingga melupakan kedekatan kita dengan musik. Padahal, kita hidup berdampingan dengan musik dan tidak akan dapat lepas dari unsur-unsur musik.

Sebagai gambarannya, mungkin saja kita lupa bahwa orang tua di Sunda senantiasa "hahariringan" dan menyanyikan lagu "Ayun Ambing" atau "Nimang" tatkala mengasuh dan menidurkan anak, atau secara konvensional orang tua menyanyikan lagu "Nina Bobo" dan menggunakan "Music Box" untuk "menina bobokan" anaknya. Karena menurut hasil penelitian Hargreaves (dalam The Developmental Psychology of Music, 1986), bahwa musik yang 
berirama dan berfrekuensi lembut dapat membuat bayi berhenti menangis. Artinya, musik tidak dapat lepas dari kehidupan kita, dan terbukti sangat bermanfaat baik bagi orang tua maupun bagi anak-anak.

Bahkan, menurut al-Suhrawardi, musik bagi sebagian orang seperti makanan, bagi sebagian orang seperti obat, dan bagi sebagian orang yang lain seperti kipas. Dengan kata lain, musik dapat berfungsi sebagai energi, penyembuh, dan penyejuk jiwa manusia. Sebagaimana yang dikatakan Syarif, ed., bahwa musik merupakan pemulih energi yang hilang, penyejuk perasaan, serta pengobar perasaan dan aspirasi yang halus (Muhaya, 2003:6).

Plato pun pernah menggunakan musik sebagai instrumen pendidikan yang lebih kuat daripada instrumen lainnya. la yakin bahwa anak-anak harus diajari musik terlebih dahulu sebelum yang lain. Karena, dalam belajar memerhatikan ritme dan harmoni yang indah kesadaran menyeluruh mereka akan menjadi tertata. Bahkan, seorang jenius terbesar pun, Albert Einstein, mengungkapkan bahwa kecintaan terhadap musik dan riset besar fisikanya, keduanya lahir dari sumber yang sama dan keduanya saling melengkapi. Oleh sebab itu, Jules Combarie mengungkapkan bahwa musik adalah seni berpikir dengan suara (Rose \& Nicholl, 2006).

Seorang sufi dari India yang berlatar belakang sebagai musisi, Inayat Khan (2007:44), menuliskan bahwa "cara terbaik mendidik anak adalah menampilkan kehadapannya segala sesuatu yang patut ditiru, misalnya suara, nada, dan irama. Apa pun yang berkaitan dengan nada dan irama akan membangun dan mempercantik karakternya, serta membentuk fondasi karakter di masa kecil”. Setidaknya, musik dieksplorasi, diklarifikasi, dan diaplikasikan kepada anak-anak agar musik yang memiliki nilai positif dapat dipahami anak serta karakternya terbentuk sesuai dengan 'filosofis musik' yang berakar dari 'konsep estetik' (baca: Music Matters, 1995). Karena jika rasa estetis telah merasuki jiwa manusia dan berhasil diresapi, sedikitnya dapat membantu dalam memahami bahwa musik sangat bermanfaat dalam kehidupan. Seperti yang 
dikatakan Nashr, ed., bahwa musik dapat mengasah daya pikir, memperhalus sifat, menggerakan jiwa, menyenangkan, dan memberi semangat kepada hati (Muhaya, 2003).

Begitu juga Campbell (baca: Efek Mozart, 1997), la mengungkapkan bahwa efek-efek luar biasa bunyi-bunyi yang ditimbulkan sendiri seperti nada, nyanyian, mantra, dan rap, bukan saja mendekatkan kita ke roh ilahiah, melainkan juga, pada tingkat yang lebih duniawi dan praktis, menawarkan cara-cara untuk meringankan rasa sakit, mengendalikan ketegangan sehari-hari, dan meningkatkan vitalitas. Bahkan, al-Ghazali (dalam Ihya Clumuddin) mengatakan nyanyian yang merdu mengungkapkan apa yang tersembunyi di dalam hati dan menciptakan perasaan yang menakjubkan. Perasaan yang tersembunyi dibawa dan diungkapkan keluar dengan suara yang manis, merdu, indah, dan berirama. Karena itu, jika manusia hatinya tidak tergerak oleh musik, maka ada penyakit yang bersarang dihatinya.

\section{Perilaku Musikal}

Dalam penelitiannya, Djohan (2003) menemukan bahwa musik sebagai bagian dari seni adalah bentuk perilaku manusia yang unik dan memiliki pengaruh yang kuat. Kita dapat memahami musik sebagai perilaku setidaknya dengan mengkaji dari fenomena seharihari yang sering kita temui. Seperti kita ketahui, bahwa musik memiliki unsur-unsur seperti irama, nada, ritmik, dan sebagainya. Ketika pada gilirannya semua unsur tersebut disatukan, maka akan terciptalah suatu harmonisasi tersendiri. Dalam kehidupan kita, nampaknya semua unsur tersebut tidak akan bisa dipisahkan lagi. Karena, pada dasarnya manusia adalah makhluk yang senantiasa diberikan rasa untuk mencintai dan menikmati keharmonisan atau keindahan. Dengan kata lain, perpaduan unsur musik telah menjadi bagian dari kehidupan dan perilaku manusia.

Bahkan, tidak hanya bagian dari kehidupan manusia, tapi juga seluruh kehidupan di jagat raya. Seorang filsuf Yunani, Phythagoras (lqbal dalam Muhaya, 2003), menyatakan bahwa suara-suara itu 
adalah aksiden ('aradh) yang bertempat pada substansi melalui gerakan. Putaran ruang angkasa yang menggerakan planet-planet dan bintang-bintang itu memiliki nada (ritme), serta menghasilkan musik yang mengagungkan dan memuliakan Tuhan. Lebih dalam la menjelaskan, bahwa musik tersebut menggembirakan jiwa para malaikat, sebagaimana jiwa kita di dunia ini menikmati lagu-lagu dan kemudian mendapatkan kesegaran kembali dari segala persoalan dan kesedihan. Karena itu, Phythagoras mengatakan, filsafat adalah kebahagiaan yang sejati, sedangkan jalan keselamatan dan pemurnian (pembersihan jiwa) adalah musik yang paling tinggi (Muhaya, 2003).

Al-Shafa pun mengungkapkan, gerakan-gerakan di jagat raya menimbulkan suara yang indah (nyanyian), yang harmonis, terpadu, silih berganti, dan enak didengar. Musik yang dihasilkan oleh gerakan jagat raya tersebut berfungsi membahagiakan jiwa ahli langit, malaikat, dan jiwa-jiwa yang bercahaya, yaitu jiwa-jiwa yang substansinya lebih mulia daripada substansi alam jagat raya. Oleh sebab itu, Bali mengatakan musik samawi berfungsi mengatur (tanzhim) gerakan bintang-bintang, sebagaimana musik dunia mengatur kehidupan manusia (Muhaya, 2003).

Dalam kehidupan manusia, terkadang tidak disadari bahwa segala aktivitas tidak dapat lepas dari peristiwa musikal. Misalnya, saat berbicara, disitulah terjadi peristiwa bunyi, tanpa bunyi kita tidak dapat berbicara. Bahkan, agar lebih enak didengar, bicara pun menggunakan alunan nada sesuai konteks pembicaraan. Atau lihat saja tatkala orang beribadah, semuanya menggunakan unsur-unsur musik. Bagi umat muslim, peribadatan tidak dapat lepas dari keindahan musik, seperti dalam membaca shalawat, mengumandangkan adzan, atau membaca al-Qur'an. Bahkan, bagi sebagian sufi musik merupakan alat stimulus ilahiah yang dapat meningkatkan kecintaan mereka kepada Allah. Bagi umat Kristen, peribadatan tidak lepas dari nyanyian. Begitu juga dengan umat lainnya, peribadatan tidak lepas dari musik. Seperti pada abad pertengahan dimana para pendeta menggunakan musik untuk 
membantu mereka menghapal teks-teks kitab suci yang panjang (Rose \& Nicholl, 2006).

Kita pun dapat hidup secara harmonis adalah karena adanya salah satu unsur musik, yakni irama. Contoh kecilnya, perhatikan saja kehidupan di jalan raya, kita dapat merasakan enaknya berkendara jika antara satu dengan yang lainnya seirama, tidak ada yang terlalu pelan sehingga menghalangi, atau terlalu cepat sehingga membahayakan. Seperti halnya berjalan, dengan pola irama atau ritme tertentu kita dapat merasakan enaknya berjalan atau berlari.

Kita berada dalam suatu aturan pola irama, bahkan kita ditakdirkan untuk memiliki dan menjalankan suatu pola irama dalam tubuh kita. Yaitu pola irama detakan jantung dan nadi yang memiliki ritme tertentu. Kita semua tahu apa yang akan terjadi seandainya detakan jantung berhenti untuk berirama, tentu tidak ada lagi keindahan di dunia. Oleh sebab itu, pada dasarnya manusia adalah makhluk yang tidak dapat dipisahkan dari musik. Gerakan-gerakan manusia adalah bagian dari peristiwa musikal duniawi. Keindahan dan keharmonisan merupakan hasil dari unifikasi antara manusia dan musik. Musik telah menjadi bagian dari diri manusia, dan menjadi perilaku dalam kehidupan manusia sehari-hari. Jadi, musik tidak hanya dapat dinikmati sesaat, namun dapat dinikmati selama kita menyadari bahwa hidup kita adalah bagian dari musik.

\section{Daftar Pustaka}

Al-Ghazali. (2005). Ihya Ulumuddin. Bandung: Marja.

Campbell, Don. (2002). Efek Mozart. Jakarta: PT. Gramedia Pustaka Utama.

Djohan. (2003). Psikologi Musik. Yogyakarta: Buku Baik. Elliot, David J. (1995). Music Matters. New York: Oxford University Press.

Hargreaves, D.J. (1986). The Developmental Psychology of Music. New York: Cambridge University Press. 
Hermawan, Deni. (2002). Etnomusikologi: Beberapa Permasalahan dalam Musik Sunda. Bandung: STSI Press.

Khan, Inayat. (2007). Mendidik Sejak dari Kandungan Hingga Dewasa. Bandung: Marja.

Muhaya, Abdul. (2003). Bersufi Melalui Musik: Sebuah Pembelaan Musik Sufi oleh Ahmad al-Ghazali. Yogyakarta: Gama Media.

Rose, Collin \& Nicholl, M.). (2006). Accelerated Learning. Bandung: Nuansa.

Sasaki, Mariko. (2007). Laras Pada Karawitan Sunda. Bandung: P4ST UPI. 


\section{Bab 2}

\section{OIGusIK PADA DIRI MANUSIA}

\section{Potensi Musikal Individu}

Al-Ghazali (2005:107) mengungkapkan, "sesungguhnya di dalam hati itu terdapat permata yang sangat berharga, sebagaimana tersembunyinya api pada batu dan besi. Tersembunyinya tambang permata dalam hati tersebut seperti tersembunyinya air di bawah tanah. Sesungguhnya tidak ada cara atau sarana untuk membangunkan dari tidur selain dengan suara-suara yang lembut". Berangkat dari pandangan tersebut, betapa musik sangat diperlukan dalam kehidupan manusia. Tidak hanya sebagai media penghibur, namun berfungsi juga sebagai alat untuk membuka dan menemukan keajaiban hati. Oleh sebab itu, pada dasarnya manusia diciptakan untuk hidup berdampingan, saling mengisi dan melengkapi dengan musik.

Dengan demikian, manusia diciptakan dengan kemampuan untuk memahami musik. Meskipun dalam realitanya memiliki pemahaman yang berbeda ikhwal konsep musik. Tidak menyadari bahwa setiap individu memiliki potensi musikal yang terkandung dalam dirinya. Seperti suara yang digunakan untuk berbicara, atau bunyi-bunyian yang ditimbulkan oleh gerakan-gerakan jasmaniah. Artinya, tidak terbatas pada pengertian musik yang selalu berhubungan dengan seni-seni pada umumnya, seperti seni suara atau seni musik vokal. Karena jika hanya terpatok pada musik seperti itu, maka dapat dipastikan tidak akan pernah menyadari bahwa setiap individu memiliki potensi musikal yang baik, dan terus berkembang untuk mencapai kesempurnaan musikal baik secara alamiah maupun dengan cara penyempurnaan tersendiri. 


\section{Perkenalan dengan Musik}

Bagaimana pun juga, setiap individu tidak akan lepas dari musik, karena sejak dalam kandungan telah dikondisikan untuk menerima bentuk-bentuk musikal. Seperti hasil penelitian Alfred Tomatis, bahwa telinga mulai berkembang begitu kehamilan menginjak usia sepuluh minggu dan berfungsi pada usia empat setengah bulan. Lebih dalam la menjelaskan, bahwa janin mendengar semua rentang bunyi-bunyi frekuensi rendah yang utama... alam bunyibunyian dimana embrio berada sangatlah kaya dengan segala macam jenis bunyi... derau internal, pergerakan khilus pada saat terjadi pencernaan, dan irama jantung yang semacam derap langkah (Campbell, 2002:22). Dengan demikian, perkenalan dengan musik telah dimulai sejak manusia berada di alam kandungan. Bahkan, selain bunyi-bunyian yang diterima dan bersifat alamiah, ada juga bunyi yang diterima karena sengaja diperdengarkan. Misalnya, melalui orang tua yang secara sengaja mendengarkan musik karena suka, atau orang tua yang hanya kebetulan mendengarkan musik tatkala mengandung.

Di awal kelahiran pun, setiap individu tidak terlepas dari perkenalan dengan bunyi-bunyian. Misalnya, suara orang tua dan orang-orang di sekitar yang membantu kelahiran, atau suara tangisan bayinya sendiri. Bahkan, bagi umat muslim di awal kelahiran dikondisikan untuk mendengarkan suara adzan yang memiliki fungsi rohaniah. Secara tidak langsung, beberapa peristiwa tersebut merupakan fase-fase awal manusia diperkenalkan dengan musik. Terlepas dari kemampuan organorgan tubuh atau indera untuk dapat menerima bunyi-bunyian tersebut. Sebagaimana dikemukakan Hurlock (1978) bahwa pendengaran merupakan salah satu dari seluruh indera yang paling sedikit perkembangannya pada saat kelahiran.

Alasan pertama, karena di telinga bagian tengah terhambat oleh cairan amnion, sehingga gelombang suara tidak dapat menembus ke sel indera di telinga bagian dalam, dan bayi tidak dapat mendengar beberapa jam atau hari sesudah lahir. Kedua, sel indera 
di telinga bagian dalam baru sebagian berkembang. Sehingga suara yang berfrekuensi rendah lebih efektif untuk menghentikan tangisan. Apalagi suara yang terus menerus, mempunyai pengaruh yang lebih menenangkan daripada yang terputus-putus (Hurlock, 1978:97). Dengan demikian, musik akan menghampiri setiap individu dalam bentuk yang berbeda-beda.

\section{Perkembangan Musikal Individu}

Karena setiap individu akan menerima segala bentuk bunyibunyian, maka musik yang diterima pun akan dikontruksi dan berkembang, baik secara alamiah maupun secara sengaja dikembangkan. Untuk melihat perkembangan musikal pada setiap individu, dapat dikaji dengan melihat dua fenomena. Pertama, perkembangan musikal secara alamiah. Hal ini dapat dilihat dari perkembangan suara manusia, seperti kemampuan dalam mengeluarkan suara untuk berbicara (masa vokalisasi). Dalam perkembangannya, manusia mengalami beberapa tahapan untuk dapat berbicara sesuai dengan perkembangan organ-organ tubuh.

Hurlock (1978:178), menyebut masa vokalisasi tersebut sebagai bentuk komunikasi. la membaginya ke dalam dua tahapan, yakni masa prabicara (prespeech) dan masa bicara. Pada masa prabicara, komunikasi terbagi ke dalam empat bentuk, yakni tangisan, celoteh, isyarat, dan ekspresi emosional. Dari keempat bentuk komunikasi tersebut, dapat menunjukan bahwa setiap individu mengalami perkembangan dalam hal musikalitas, di antaranya vokalisasi atau proses pembentukan nada untuk bicara. Apalagi jika individu berhasil sampai dapat berbicara, berarti bentuk musikalitas dalam dirinya berkembang dengan baik. Bahkan, bagi individu yang mengalami ketidaksempurnaan sekalipun, seperti tuna wicara, pembentukan nada terus berkembang. Hanya saja tidak dapat membentuk kata-kata dan artikulasi yang baik. Namun, pada dasarnya tetap mengalami perkembangan secara musikal. Misalnya, dapat bersuara dengan menggunakan dinamika atau alunan nada. 
Perkembangan musikal pada diri individu tidak hanya terjadi pada aspek bunyi saja, tapi juga terjadi pada aspek ritme kejiwaan. Inayat khan (2007:13-16) mengungkapkan, bahwa anak adalah bagian dari ibunya, ritme jiwa sang ibu sama dengan anak. Lebih dalam la menjelaskan, bahwa salah satu cara untuk mengajarkan keseimbangan kepada anak adalah dengan mengatur ritme saat ritmenya tidak beraturan. Misalnya, saat anak menangis, maka alihkanlah pikiran anak supaya ritme anak kembali ke ritme yang normal. jika anak terus mengalami perlakuan seperti itu, dan semakin dewasa semakin mengerti serta dapat kembali pada ritme yang normal dengan sendirinya, berarti telah mengalami perkembangan musikal dengan baik, terutama dalam hal ritme kejiwaan.

Bagi remaja atau orang dewasa pun, ritme kejiwaan terus berkembang. Misalnya, disaat individu mengalami goncangan jiwa karena putus cinta, maka kecerdasan emosionalnya terganggu sehingga mengakibatkan ritme kehidupannya menjadi tidak normal. jika dibiarkan terus berlarut-larut, maka ritme kejiwaannya akan terus terganggu. Namun, dengan berupaya semaksimal mungkin untuk menormalkan kembali ritme jiwanya bahkan sampai berhasil kembali normal, berarti individu tersebut telah mengalami perkembangan musikal yang cukup baik, dan memiliki kecerdasan emosional yang cukup cerdas.

Kedua, perkembangan musikal dengan pengembangan khusus. jika individu yang secara alami saja aspek musikalnya dapat berkembang, apalagi bagi individu yang melatih dan mengembangkan secara khusus, dapat dipastikan akan mengalami perkembangan musikal yang sangat baik. Hargreaves (1986) pun mengemukakan, bahwa vokal anak mengalami perkembangan sesuai dengan kontruksi pengetahuannya ikhwal bunyi-bunyian. Begitu juga dengan ritme kejiwaan, dengan mempelajari keilmuan psikologi atau bimbingan dan konseling, maka dapat dipastikan akan memiliki perkembangan musikal yang cukup baik. 
Julia

\section{Daftar Pustaka}

Al-Ghazali. (2005). Ihya Ulumuddin. Bandung: Marja.

Campbell, Don. (2002). Efek Mozart. Jakarta: PT. Gramedia Pustaka Utama.

Hargreaves, D.J. (1986). The Developmental Psychology of Music. New York: Cambridge University Press.

Hurlock, Elizabeth. B. (1978). Perkembangan Anak. Jakarta: Erlangga.

Khan, Inayat. (2007). Mendidik Sejak dari Kandungan Hingga Dewasa. Bandung: Marja. 


\section{Bab 3}

\section{$\mathcal{P}_{\text {ENDIDIKAN MUSIK }}$}

\section{DALAM CENGKERAMAN KAPITALISME}

\section{Pendahuluan}

Jagat pendidikan musik di Indonesia syarat dengan mekanisme industri atau perdagangan. Musik merupakan barang dagangan yang bisa dengan mudah diperjual-belikan oleh berbagai kalangan. Ini menyiratkan ada dua sisi musik yang berjalan secara bergandengan namun memiliki tujuan yang berbeda. Di satu sisi musik berjalan dan berkembang sebagai komoditi yang diperjualbelikan guna memenuhi keperluan dan tuntutan industri musik, di sisi lain musik digarap sebagai bahan pendidikan. Keduanya diawali dengan hal yang relatif sama, yakni melalui proses pendidikan atau pembelajaran, namun akhirnya memiliki tujuan dan fungsi yang berbeda. Musik industri semata-mata dilakukan untuk mencari keuntungan-keuntungan bagi pihak tertentu melalui musik itu sendiri, sementara musik pendidikan mengarah pada bagaimana musik itu disebarkan sebagai sesuatu yang memiliki nilai (bersifat mendidik) dan bermanfaat bagi kemaslahatan manusia, termasuk pelaku musik itu sendiri.

Sayangnya, musik industri memiliki pengaruh cukup signifikan terhadap pendidikan musik, sehingga kekacauan yang terjadi adalah musik yang secara teks dan konteksual mudah disebarkan melalui berbagai media, kurang melirik sisi pendidikannya atau ekses yang dapat ditimbulkan khususnya bagi generasi muda. Akibatnya, tidak ada lagi batasan antara musik yang semestinya dikonsumsi oleh remaja atau orang dewasa, dan musik yang seharusnya dikonsumsi oleh anak-anak. Maka dari itu, tak heran jika anak-anak seusia sekolah dasar sudah banyak menyanyikan lagu-lagu dengan lirik ihwal percintaan orang dewasa, padahal yang paling tepat bagi 
mereka adalah lirik mengenai kecintaan mereka terhadap Tuhan, orang tua dan alam. Bagaimana kelanjutan dari fenomena ini? Tentu saja pada akhirnya anak-anak berkembang dengan mainset percintaan yang diawali sejak dini, dan ini merupakan bagian dari proses pendidikan yang terjadi secara alamiah melalui media musik. Memang pada dasarnya musik seperti itu adalah musik untuk hiburan, namun bagaimanapun juga tetap saja sedikit atau banyak ada unsur mendidiknya, karena secara perlahan dapat memengaruhi kehidupan anak-anak dalam mencapai kedewasaannya.

Salahsatu penyebab masalah ini adalah paradigma kapitalisme yang berkembang dalam jagat musik itu sendiri. Dimana para praktisi, produser, dan sponsor tidak melihat musik pendidikan sebagai produk yang menjanjikan, sehingga sama sekali tidak memedulikan persoalan musik dan pengaruhnya terhadap kalangan anak-anak, bagi mereka yang penting adalah profit. Oleh sebab itu, yang dapat dirasakan sekarang antara lain sulitnya mencari referensi-referensi musik pendidikan bagi anak yang uptodate, bahkan dalam media-media elektronik pun termasuk barang langka. Yang dapat sering diapresiasi oleh anak-anak lagi-lagi adalah musik-musik untuk orang dewasa.

Melalui pemahaman dari sebagian kecil fenomena di atas, maka dalam paper ini, penulis mencoba untuk mengkaji bagaimana sistem pendidikan di Indonesia jika dilihat dari perspektif ideologi (kapitalisme) pada umumnya? Bagaimana pengaruhnya terhadap pendidikan seni (musik)? Dan apa solusi-solusi terhadap permasalahan tersebut? Kajian ini dilakukan dengan cara pengamatan dan pemaknaan terhadap realitas yang terjadi khususnya dalam ranah pendidikan musik di Indonesia, dengan bersandar pada fakta-fakta yang ada serta disandingkan pada teoriteori yang relevan. 


\section{Landasan Teori}

Dari berbagai ideologi yang berkembang di dunia, kapitalisme merupakan salahsatu ideologi yang berpengaruh besar terhadap dunia pendidikan, khususnya dalam dunia pendidikan seni musik. Apakah yang dimaksud dengan kapitalisme tersebut? Dalam Cambridge Advanced Learner's Dictionary (2005:178) dijelaskan bahwa capitalism an economic, political and social system based on private ownership of property, businnes and industry, and directed towards making the greatest possible profits for succesful organizations and people. Berdasarkan penjelasan tersebut, dapat diketahui bahwa kapitalisme merupakan suatu sistem yang secara langsung dibuat untuk memperoleh keuntungan sebesar-besarnya, atau dengan kata lain adalah suatu paham yang meyakini bahwa pemilik modal bisa melakukan usahanya untuk meraih keuntungan sebesar-besarnya (Wikipedia, 2013).

Dengan demikian, dapat diidentifikasi pula bahwa kapitalisme merupakan suatu paham yang memiliki ketertarikan dalam upaya menumpuk kekayaan, karena keuntungan besar akan terakumulasi dalam harta benda dan menjelma sebagai kekayaan. Dikatakan oleh Mulyanto (2010:8), kapitalisme memang sistem ekonomi yang mengorganisasi upaya pengejaran dan pengumpulan kekayaan demi kekayaan itu sendiri.

Apa yang menjadi mimpi dari paham kapitalisme? Selaras dengan definisinya, bahwa paham kapitalisme memiliki mimpi untuk menguasai sistem perekonomian melalui perdagangan benda atau barang pribadi, sehingga individu atau kelompok tertentu dapat memiliki keuntungan sebesar-besarnya dari perdagangan benda atau barang-barang tersebut. Komara (2004) menuturkan, kapitalisme dibangun dengan berdasarkan prinsip pemisahan total antara Allah SWT dengan sistem yang mengatur berbagai interaksi dalam kehidupan. Ide ini merupakan akidah kapitalisme, yang sekaligus merupakan kepemimpinan dan akidah berpikirnya. Akibatnya, tujuan-tujuan mulia dalam berbagai aspek kehidupan, menjadi kacau karena semuanya tertuju pada pengumpulan 
kekayaan semata, termasuk tujuan dalam dunia pendidikan yang pada akhirnya berbelok haluan pada urusan material.

Indah (2012) menuturkan, pendidikan ala kapitalisme terbukti telah gagal mencetak generasi manusia dengan kepribadian utuh dan berkarakter, orientasi pendidikan kapitalis mengarahkan kepada manusia untuk mencapai suatu materi (nilai) dengan cara apapun itu tanpa memandang baik dan buruknya. Menurutnya, ini disebabkan oleh 2 hal mendasar, yaitu pertama paradigma pendidikan kapitalis, yang hanya bertujuan membentuk pribadi materialistik dalam pencapaian hidup, hedonistik dalam budaya masyarakat, individualistik dalam lingkungan sosial, dan tidak sejalan dengan agamanya dan kedua kerusakan fungsional dalam 3 unsur pelaksana pendidikan, yaitu lembaga pendidikan formal yang lemah (kacaunya kurikulum dan tidak berfungsinya guru sebagaimana mestinya), keluarga yang tidak mendukung, serta keadaan masyarakat yang tidak kondusif. Maka dari itu, pendidikan menjadi sebuah ritual propaganda dan produksi slogan sebagai tuntutan industrialisasi kapitalisme global (Unwanullah, 2010).

\section{Pembahasan}

\section{Kapitalisme Pendidikan}

Kapitalisme Pendidikan menurut Francis Wahono (Komara, 2012) berarti arah pendidikan dibuat sedemikian rupa sehingga pendidikan menjadi pabrik tenaga kerja yang cocok untuk tujuan ekonomi kapitalis tersebut. Dengan melihat fenomena pendidikan di Indonesia khususnya, paham kapitalisme dapat diidentifikasi telah melekat dan mengakar dalam sistem pendidikan. Hal ini dapat ditinjau setidaknya dari dua aspek berikut. Pertama, penyelenggaraan sistem pendidikan. Baru-baru ini pemerintah Indonesia telah menyelenggarakan pendidikan gratis pada tingkat pendidikan dasar, terutama dari jenjang sekolah dasar (SD) sampai tingkat sekolah menengah pertama (SMP), bahkan sudah mulai dirancang pendidikan gratis untuk tingkat sekolah menengah atas (SMA). Pendidikan gratis ini merupakan suatu program yang 
antara lain dilakukan untuk memenuhi tuntutan UNESCO ihwal program wajib belajar di seluruh dunia, karena disinyalir, bahwa salahsatu penyebab masyarakat tidak menyekolahkan anak-anaknya antara lain karena ketidaksediaan mereka untuk membayar biaya pendidikan. Maka dari itu, program wajib belajar tanpa membayar biaya pendidikan yang diluncurkan oleh pemerintah adalah solusi untuk memecahkan persoalan tersebut. Dengan demikian, cita-cita bangsa Indonesia yang termaktub dalam Undang-Undang negara Indonesia tentang hak semua warga negara Indonesia untuk memperoleh pendidikan dapat terwujud secara menyeluruh tanpa terhalang lagi oleh kondisi ekonomi setiap keluarga. Dengan catatan, bahwa program wajib belajar yang gratis tersebut tetap terjaga kualitasnya di setiap sekolah agar peserta didik pun tetap mendapatkan pendidikan yang berkualitas secara merata.

Namun apa yang terjadi, pikiran kapitalisme rupanya telah merasuki sistem pendidikan di Indonesia. Dengan dalih meningkatkan kualitas peserta didik, diciptakanlah kluster-kluster dalam sistem pendidikan, yakni munculnya kelas-kelas bertaraf internasional di berbagai sekolah dengan biaya tertentu, sehingga kelasnya pun dibedakan dari kelas gratis. Yang tentu saja, penyelenggaraan kelas bertaraf internasional tersebut menyiratkan: 1) kategorisasi dalam peserta didik, 2) pembedaan kualitas pembelajaran, dan 3) pemunculan stratifikasi sosial dalam peserta didik. Seorang ahli pendidikan, Darmin Vinsensius, mengatakan bahwa RSBI itu mengabaikan kewajiban negara memajukan untuk kesejahteraan umum sebab RSBI sebagai pendidikan dengan sebagai komoditas global berbasis nilai kapitalisme neoliberal (Arif, 2012). Maka dari fenomena tersebut, timbul kecurigaan terhadap pihak-pihak tertentu yang berkepentingan untuk mencari keuntungan dari penyelenggaraan kelas bertaraf internasional. Dengan kata lain, di saat kucuran dana berkurang yang antara lain bersumber dari SPP peserta didik sebagai dampak dari program pendidikan gratis, maka strategi untuk mencari keuntungan adalah dengan menyelenggarakan kelas bertaraf internasional. 
Ini seperti dituturkan oleh pengamat pendidikan, Muhammad Abduhzen, bahwa sekolah berstandar internasional didefinisikan sebagai sekolah berbiaya mahal yang menggunakan bahasa Inggris sebagai bahasa pengantar. Dan ini menimbulkan peluang untuk mengeruk dana pendidikan sebanyak-banyaknya (Nurfuadah, 2013). Maka dari itu, RSBI bukan hanya dipandang sebagai program yang disinyalir memiliki kepentingan pihak tertentu dalam mengumpulkan kekayaan, tapi juga notabene bertentangan dengan prinsip konstitusi yang menuntut adanya persamaan dalam penyelenggaraan pendidikan bagi warga negara Indonesia. Hal senada diungkapkan pula oleh Azkiya (2013), bahwa komersialisasi sektor pendidikan semacam RSBl bertentangan dengan prinsip konstitusi. Padahal, jelas, UUD 1945 pasal 31 ayat 1 menyebutkan setiap warga negara berhak mendapat pendidikan. Jika status sekolah itu dipertahankan, perlakuan berbeda antara sekolah SBI atau RSBI dan sekolah biasa makin terlihat. Dengan demikian, penghapusan $\mathrm{RSBl} / \mathrm{SBl}$ oleh pemerintah adalah langkah yang dinilai tepat untuk meluruskan kembali cita-cita mulia pendidikan di Indonesia.

Kedua, penyelenggaraan UN. Kekacauan yang terjadi dalam penyelenggaraan UN, seperti kebocoran soal yang terorganisir karena melibatkan kepala sekolah dan panitia penyelenggara, merupakan salahsatu bukti dari berjalannya kapitalisme secara halus dalam sistem pendidikan di Indonesia. Artinya, yang menjadi tujuan utama dari para komponen pendidikan, adalah upaya untuk mendapatkan materi dengan berbagai cara. Padahal, yang menjadi tujuan pendidikan seyogianya adalah pembentukan kepribadian peserta didik yang berakhlak baik dan berbudi luhur - yang tentu saja mesti dimulai dari para penyelenggara pendidikannya sendiri.

\section{Kapitalisme dalam Pendidikan Musik}

Pendidikan ala kapitalisme dalam pendidikan musik berpengaruh terhadap beberapa hal berikut. Pertama, dalam proses pendidikan informal. Proses pendidikan seni musik atau dengan 
kata lainnya proses pewarisan seni dalam tataran informal, senantiasa dilakukan dengan metode oral tradisi melalui tatap muka secara intensif antara guru dan muridnya. Cara-cara ini memang telah menjadi ciri dari pembelajaran seni tradisi khususnya di Indonesia atau negara-negara timur pada umumnya. Hasilnya pun telah terbukti bahwa sampai saat ini masih banyak para praktisi seni yang menguasai keahlian melalui cara-cara oral tradisi, sehingga berbagai genre seni pun masih bisa dilestarikan.

Namun muncul pula persoalan yang cukup sensitif, seperti yang terjadi di tatar Sunda, dimana pada akhir riwayat pembelajaran (setelah tuntas belajar/privat) sering kali terjadi perpecahan antara guru dan murid dikarenakan munculnya feodalisme dalam relasi yang dijalin guru dan murid tersebut. Faktanya bahwa sang guru baik secara implisit maupun eksplisit menjadi menguasai dan cenderung memiliki kekuatan untuk mengendalikan sang murid, sehingga sang murid pada kondisi tertentu dituntut untuk memenuhi keperluan sang guru dari sisi materi, dan relatif sulit untuk melepaskan diri dari kondisi tersebut. Yang lazim terjadi, jika sang murid melepaskan diri maka perpecahanlah yang terjadi di antara keduanya. Ini merupakan fenomena nyata yang antara lain disebabkan oleh sistem kapitalis yang telah merasuki berbagai lini kehidupan dan bidang ilmu melalui cara-cara yang halus, sehingga proses regenerasi seni pun yang dianggap suatu pekerjaan yang mulia tetap diakhiri dengan pencarian materi yang dilakukan secara halus pula. Karena di sini proses pendidikan pada dasarnya adalah bersifat memberi - dari guru kepada murid, dan memberi itu tidak mengharapkan imbalan, sekalipun sang murid membalas dengan memberikan sesuatu. Menurut Jacques Derrida (Hali, 2013:267), memberi yang merupakan eskpresi kesalehan, sikap altruisme (kepedulian), dan bentuk perhatian pada orang lain berubah maknanya dalam logika ekonomi. Dituturkan oleh Hali (2013:267), bahwa memberi dan menerima berupa imbalan atau bayaran merupakan logika khas ekonomi kapital. 
Kedua, dalam produksi dan publikasi musik. Kapitalisme yang terjadi dalam produksi dan publikasi musik mengakibatkan konten atau muatan nilai yang terkandung dalam musik tidak begitu dipertimbangkan lagi. Sasarannya adalah musik laku di pasaran, semakin banyak yang membeli ya semakin kaya, tidak peduli apa kandungan morilnya. Sementara di sisi lain, jika konten musik yang tidak mengandung pesan-pesan moral semakin banyak terjual di pasaran, maka sama saja dengan menyebarkan potensi terhadap berbagai kalangan termasuk anak-anak untuk menikmati maknamakna musik yang belum pantas untuk dinikmati.

Ketiga, dalam lomba nyanyi. Di Indonesia sekarang memang sudah menjadi populer penyelenggaraan acara-acara perlombaan dalam jagat musik yang sarat dengan kepentingan kaum kapitalis. Di sini jelas terlihat sedikitnya ada dua masalah yang menjadi sorotan: 1) arah perlombaan yang mengacu pada popularitas. Apakah salah jika peserta audisi vokal dan sejenisnya memiliki keinginan untuk menjadi populer? Tentu saja tidak, yang menjadi masalah adalah perilaku dan orientasi hidup setelah menjadi bintang yang populer. Kepopuleran identik dengan publik figur, namun sayangnya setelah menjelma sebagai publik figur, menjadi tidak patut untuk dicontoh, mulai dari penampilan dan gaya hidup sehari-hari. Karena itu semua lagi-lagi mengarah pada gaya hidup kapitalisme, mengeruk kekayaan sebanyak-banyaknya, seolah-olah lupa bahwa dirinya tengah menjadi sorotan publik yang notabene dapat memberikan pengaruh-pengaruh buruk terhadap kalangan masyarakat luas.

2) pemilihan lagu yang tidak tepat. Ajang pencarian bakat dan popularitas melalui lagu seringkali tidak memerhatikan faktor kesesuaian makna lagu dengan tingkat perkembangan peserta lomba, yang jadi perhatian rata-rata pada aspek teknik bernyanyi, ekspresi dan penampilan peserta. Sementara itu, unsur pendidikan bagi anak yang antara lain terletak pada makna lagunya karena secara kontekstual dapat secara langsung bersentuhan dengan kehidupan nyata mereka, senantiasa tidak menjadi perhatian. 
3) proses pendidikan (pencapaian juara) yang dipenuhi dengan kepentingan material kalangan tertentu. Kegiatan lomba nyanyi sebagai bagian dari proses pendidikan anak-anak notabene dimulai dengan orientasi yang kurang tepat. Dari awal kegiatan sudah pasti para peserta telah sepakat untuk mengikuti aturan main lomba yang penilaiannya tidak hanya ditentukan oleh juri lomba secara langsung, namun melalui voting suara yang dilakukan secara berbayar melalui SMS oleh siapa saja yang mau berpartisipasi. Ini jelas telah masuk pikiran kalangan tertentu untuk mengeruk keuntungan dari kegiatan tersebut, dan para peserta pun larut dalam mimpi-mimpi mereka sehingga materi pun tidak menjadi persoalan untuk terus dikeluarkan, sehingga akhirnya prestasi pun dicapai sebagai hasil berlomba dalam mengeluarkan materi sebanyak-banyaknya. Maka dapat dipastikan kemana arah prestasi tersebut setelah didapatkan jika dimulai dengan sesuatu yang material dan begitu banyak dikeluarkan, dapat dipastikan gaya kapitalis akan terus menghantuinya.

Pencapaian prestasi seperti cara-cara di atas telah mengubah tujuan suci dari kreativitas dan imajinasi seni, yang semestinya prestasi itu murni untuk pengembangan diri dan berujung pada pengembangan keilmuan, kini hadir dengan kesadaran yang berorientasi pada keuntungan. Dikatakan oleh Hali (2013:264), uang telah menguasai imajinasi dan kesadaran manusia. Bahkan kini hadir lebih dini untuk menghampiri imajinasi dan kesadaran anak-anak melalui iming-iming popularitas.

\section{Solusi Pendidikan Musik}

Melihat pendidikan musik yang terbalut dengan sistem kapitalisme, setidaknya ada beberapa solusi yang patut dilayangkan sebagai upaya mendidik generasi muda melalui pendidikan musik. Pertama, pemerintah mesti menghentikan segala praktek pendidikan yang mengarah pada dikotomi dan stratifikasi sosial yang terimplementasikan melalui stratifikasi kelas dan nama sekolah. Kembalikan tujuan pendidikan pada cita-cita bangsa yang 
mulia - dimana semuanya berhak mendapatkan pendidikan yang sama. Kedua, perlu diciptakan sistem pendidikan yang baku dan fleksibel dalam ranah pendidikan informal, sehingga ada kejelasan relasi dan arah pembelajaran, karena di zaman sekarang sudah cukup sulit mencari guru yang tidak berorientasi pada materi. Padahal, dunia pendidikan informal sudah lazim menjadi tempat berkembang dan turun-temurunnya nilai-nilai kearifan lokal. Artinya, dalam dunia kearifan lokal sekalipun sekarang ini sudah dirasuki dengan sistem kapitalis. Ketiga, perlu diklasifikasikan antara ajang-ajang lomba yang bermuatan nilai-nilai untuk orang dewasa dengan anak-anak, sehingga pemahaman anak-anak dapat berkembang sesuai kebutuhannya. Keempat, kondisikan anak untuk mengukir prestasi secara murni. Pengkondisian ini sangat dipengaruhi oleh peranan orangtua sebagai orang yang lazimnya mengantar dan mengikuti kemauan sang anak. Ada kalanya anak mengikuti perlombaan karena justru mengikuti pikiran orangtuanya yang berorientasi pada materi, sehingga anak sebenarnya terkondisikan secara tidak langsung oleh tujuan orangtuanya.

\section{Kesimpulan}

Berdasarkan paparan di atas maka dapat disimpulkan bahwa kapitalisme telah merasuki berbagai aspek kehidupan. Banyak hal yang berkembang karena didorong oleh sistem kapitalisme, namun sekaligus juga memberikan dampak negatif terhadap aspek tertentu. Salahsatunya dunia pendidikan yang notabene telah berjalan sesuai dengan gaya khas kapitalis, yakni segala urusan pendidikan selalu terjalin dalam hubungan transaksional, memberi dan mengharap imbalan, serta orientasi pendidikan yang dibuat untuk mengeruk berbagai keuntungan. Begitu juga ranah pendidikan musik, dalam proses atau pelaksanaannya sudah susah dilepaskan dari jeratan gaya kapitalisme. 


\section{Daftar Pustaka}

Arif, Muhamad. (2012). Brand 'Sekolah Internasional' Ala Pemerintah Dorong Kapitalisme Pasar. Diambil 04 Oktober 2013.

Tersedia:

http://news.detik.com/read/2012/03/20/163320/1872437/10/brandsekolah-internasional-ala-pemerintah-dorong-kapitalisme-pasar.

Cambridge Advanced Learner's Dictionary. (2005). Cambridge: Cambridge University Press.

Hali, Damianus, J. (2013). Humanisme dan Peradaban Global. Dalam Bambang Sugiharto. (ed). (2013). Humanisme dan Humaniora. Bandung: Matahari.

Indah, Mei. (2012). Kapitalisme Merusak Pendidikan. Diambil 03

Oktober 2013.

Tersedia:

http://news.detik.com/read/2012/06/19/112358/1944825/471/1/kapit alisme-merusak-pendidikan.

Komara, Endang. (2012). Peran Kapitalisme Pendidikan dalam Era Globalisasi. Diambil 03 Oktober 2013. Tersedia: http://www.geocities.ws/endang.komara/PERAN_KAPITALISME_P ENDIDIKAN_DALAM_ERA_GLOBALISASI.

Mulyanto, Dede. (2010). Kapitalisme: Perspektif Sosio-Historis. Bandung: Ultimus.

Nurfuadah, Rifa Nadia. (2013). Logika Kapitalisme dalam RSBI. Diambil $04 \quad$ Oktober 2013. Tersedia: http://kampus.okezone.com/read/2013/01/09/373/743434/logikakapitalisme-dalam-rsbi.

Unwanullah, Arif. (2010). Industrialisasi Sektor Pendidikan (Berkah Atau Bencana Bagi Dunia Pendidikan). Jurnal Ilmiah Prospektus. Edisi 12 Tahun 2010. Tersedia:

http://ejournal.unirow.ac.id/ojs/index.php/unirow/article/view/15. Wikipedia. (2013). Kapitalisme. Diambil 03 Oktober 2013. Tersedia: http://id.wikipedia.org/wiki/Kapitalisme. 


\section{Bab 4}

\section{§ TRATEGI MEMBANGun KOMPETENSI PROFESIONAL GURU MUSIK SEKOLAH DASAR}

\section{Latarbelakang Masalah}

Dalam satu perspektif, pendidikan musik di sekolah dasar saat ini pada umumnya belum sampai pada titik yang membanggakan, jika dipandang dari ekses atau dampak pendidikan musik terhadap vokasi dan perilaku peserta didik. Setidaknya disinyalir adanya akar masalah yang menyebabkan hal itu terjadi, antara lain masalah yang mendasar terkait dengan sistem pendidikan guru musik dan kompetensi profesional guru musik sendiri. Jika melihat kompetensi yang diperlukan oleh seorang guru musik berdasarkan pada kompetensi inti dan kompetensi guru mata pelajaran yang dibuat oleh pemerintah, begitu banyaknya kompetensi profesional guru khususnya yang berkaitan dengan pembelajaran musik beserta materi yang harus disampaikan kepada peserta didik.

Sementara itu, pendidikan musik yang didapatkan oleh para guru musik di sekolah dasar, porsinya tidak sesuai dengan tuntutan kompetensi profesional seperti yang termaktub dalam peraturan pemerintah. Kedudukan guru musik di sekolah dasar saat ini merupakan guru kelas yang mengintegrasikan beberapa mata pelajaran sebagai keahliannya, termasuk keahlian dalam bermusik. Sementara itu, perguruan tinggi yang membuka program studi pendidikan guru sekolah dasar (PGSD), pada umumnya belum memiliki program khusus untuk jalur guru musik di sekolah dasar, yang tersedia baru PGSD Kelas dan PGSD Penjas, sehingga akibatnya mereka yang mengajar musik di sekolah dasar pada umumnya adalah bukan guru yang benar-benar kompeten dalam hal musik, karena memang bukan spesialisasinya. Dan pada kenyataannya mengajar musik itu perlu keahlian khusus, karena 
musik bukan sekedar teori, tapi meliputi skill-skill musikal yang perlu diasah melalui tahapan-tahapan tertentu, sehingga seperti dikatakan Zulfahmi, Nuri Sidauruk \& Zainuddin (2013), siswa bukan sekedar dijadikan sebagai objek saja melainkan juga sebagai subjek langsung atau pelaku dalam proses pembelajaran. Idealnya, untuk menjadi pengajar musik yang profesional diperlukan keprofesionalan dalam ilmu musik itu sendiri, baik dalam hal praktek maupun teori, bahkan menurut Djohan (2003:159), untuk menjadi seorang musisi profesional adalah lebih kurang 10.000 jam latihan selama kehidupan mereka.

Dengan demikian, tidaklah mengherankan apabila hasil belajar musik di sekolah dasar tidak terlalu membuahkan hasil yang signifikan pada pengembangan vokasi dan perubahan perilaku peserta didik, karena perubahan itu merupakan tahapan kedua setelah tahapan pertamanya yakni mendapatkan pengalaman estetis melalui belajar musik dengan materi yang tepat dan metode yang benar, ditempuh dengan baik. Kurangnya pemahaman sebagian besar guru terhadap seni, di antaranya mencakupi pengetahuan, wawasan, konsep, pemikiran, penyusunan kurikulum seni, menentukan dan memilih materi pengajaran kesenian; sehingga sangat mempengaruhi anak didik dalam persepsi dan apresiasi seninya (Hartono, 2007:100). Bahkan yang terjadi, peserta didik di sekolah dasar tidak mendapatkan pengalaman musikal seperti yang diharapkan karena kualitas guru musiknya sendiri kurang kompeten baik dalam penguasaan materi-materi musik maupun metode pembelajarannya. Sementara kualitas profesional guru (kemampuan dan kepribadiannya) secara langsung mempengaruhi kualitas PBM. Dengan pengertian lain, penentuan akhir keberhasilan peningkatan mutu pendidikan berada pada tangan guru di depan kelas (Djailani, 1997:11). Maka dari itu, tulisan ini berupaya untuk mengkaji bagaimana idealnya pendidikan musik bagi calon guru-guru sekolah dasar, supaya kompetensi profesionalnya sebagai guru musik dapat tercukupi serta dapat dipertanggungjawabkan. 


\section{Kompetensi Profesional}

Kompetensi profesional merupakan satu dari empat kompetensi yang wajib dimiliki oleh guru seperti termaktub dalam UndangUndang Guru dan Dosen nomor 14 tahun 2005 pasal 10 ayat 1, bahwa kompetensi guru sebagaimana dimaksud dalam Pasal 8 meliputi kompetensi pedagogik, kompetensi kepribadian, kompetensi sosial, dan kompetensi profesional yang diperoleh melalui pendidikan profesi. Wahyudi (2010:108) memaparkan bahwa kompetensi profesional dijelaskan dalam bahan sosialisasi sertifikasi guru mencakup sub kompetensi sebagai berikut: (1). menguasai substansi keilmuan yang terkait dengan bidang studi yaitu; memahami materi ajar yang ada dalam kurikulum sekolah, memahami struktur, konsep dan metode keilmuan yang menaungi atau koheren dengan materi ajar, memahami hubungan konsep antar mata pelajaran terkait, dan menerapkan konsep-konsep keilmuan dalam kehidupan sehari-hari, dan 2). menguasai langkahlangkah penelitian dan kajian kritis untuk menambah wawasan dan memperdalam pengetahuan/materi bidang studi. Berdasarkan paparan tersebut, kompetensi profesional salahsatunya menekankan pada aspek kemahiran dalam keilmuan yang menjadi bidang keahlian guru. Dengan demikian, bagi guru musik kompetensi profesional antara lain menukik pada persoalan penguasaan materimateri seni beserta konsep-konsepnya.

Ini dapat dilihat melalui rumusan kompetensi inti guru mata pelajaran seni budaya seperti tercantum dalam peraturan menteri pendidikan nasional nomor 16 tahun 2007, yang mengharuskan guru seni budaya untuk dapat:

- Menguasai materi, struktur, konsep, dan pola pikir keilmuan (mencakup materi yang bersifat konsepsi, apresiasi, dan kreasi/rekreasi) yang mendukung pelaksanaan pembelajaran seni budaya (seni rupa, musik, tari, teater) dan keterampilan.

- Menganalisis materi, struktur, konsep, dan pola pikir ilmu-ilmu yang relevan dengan pembelajaran Seni Budaya. 
Rumusan di atas belum sampai pada penjabaran standar kompetensi dan kompetensi dasar (SK-KD) atau yang sekarang disebut sebagai standar kompetensi lulusan (SKL), yang tentu saja memerlukan keterampilan yang lebih spesifik karena berkaitan dengan satuan materi yang harus disampaikan kepada peserta didik beserta penggunaan indikator-indikator keberhasilan sebagai alat pengukurnya. Sebagai contohnya, berikut SK-KD seni musik di sekolah dasar:

\begin{tabular}{|l|l|l|l|}
\hline \multicolumn{1}{|c|}{ Standar Kompetensi } & \multicolumn{2}{|c|}{ Kompetensi Dasar } \\
\hline 1. & $\begin{array}{l}\text { Mengapresiasi karya seni } \\
\text { musik }\end{array}$ & 1.1 & $\begin{array}{l}\text { Mengidentifikasi unsur } \\
\text { musik dari berbagai sumber } \\
\text { bunyi yang dihasilkan oleh } \\
\text { benda bukan alat musik }\end{array}$ \\
\cline { 3 - 5 } 2. & 1.2 & $\begin{array}{l}\text { Membedakan antara nada } \\
\text { dengan irama }\end{array}$ \\
\hline Mengekspresikan diri & 2.1 & $\begin{array}{l}\text { Memeragakan dinamik } \\
\text { sederhana }\end{array}$ \\
\cline { 3 - 4 } & 2.2 & $\begin{array}{l}\text { Mengekspresikan diri } \\
\text { melalui alat musik/sumber } \\
\text { bunyi sederhana }\end{array}$ \\
\cline { 3 - 4 } & 2.3 & $\begin{array}{l}\text { Menyanyikan lagu wajib } \\
\text { dan lagu anak dengan atau } \\
\text { tanpa iringan sederhana }\end{array}$ \\
\cline { 3 - 4 } & 2.4 & $\begin{array}{l}\text { Mementaskan permainan } \\
\text { musik dengan alat musik } \\
\text { sederhana di depan } \\
\text { penonton }\end{array}$ \\
\hline
\end{tabular}

\section{Pembahasan}

Untuk memperbaiki pendidikan musik di sekolah dasar, setidaknya ada beberapa strategi yang dapat dilakukan baik oleh pihak penyelenggara pendidikan maupun pihak guru. Strategi tersebut meliputi pembenahan pada jalur pendidikan musik untuk jenjang sekolah dasar dan peningkatan kompetensi guru musik di sekolah dasar. 


\section{Pendidikan dan Kompetensi Guru Musik Sekolah Dasar}

\section{a. Masalah}

Dapat diidentifikasi bahwa guru-guru musik yang mengajar di sekolah dasar saat ini berdasarkan kualifikasi akademiknya terdiri atas beberapa kategori berikut:

1) Seniman Alam (non akademik)

'Seniman alam' merupakan istilah bagi praktisi seni di Jawa Barat yang belajar seni bukan dari sekolah formal, tapi biasanya belajar secara otodidak atau 'nyantrik' baik dari lingkungan keluarga atau masyarakat sekitarnya. Ini merupakan kategori guru yang biasa diperbantukan di sekolah karena memiliki keahlian dalam musik. Guru seperti ini lazimnya memiliki skill dalam memainkan alat musik atau vokal, namun senantiasa kurang memiliki kemampuan pedagogik, sehingga kecenderungannya mengajar musik tidak mengacu pada kurikulum atau kompetensi dasar seperti di instruksikan oleh pemerintah, tapi mengajar sesuai dengan selera, apa yang mereka bisa maka itulah yang diajarkan.

Dengan demikian, ukuran keberhasilan bagi kategori guru ini, adalah peserta didik mampu memainkan alat musik seperti yang mereka bisa dan mereka ajarkan, kurang peduli pada apa kata kompetensi dasarnya. Misalnya, seorang pemain perkusi seperti kendang, maka senantiasa mengajarkan rampak kendang pada peserta didik. Yang penting peserta didik mampu memainkan rampak kendang sesuai kehendak mereka. Maka dari itu, kecenderungannya guru tipe ini mengajarkan rampak kendang selama satu semester penuh. Padahal, menurut kurikulum masih ada kompetensi lain yang mesti dikenalkan kepada peserta didik disertai evaluasi autentik berdasarkan indikator keberhasilannya.

\section{2) Guru Asal PGSD}

Guru musik tipe ini merupakan guru yang senantiasa paham pada kurikulum atau kompetensi dasar sekolah dasar dan ilmu pedagogik, karena memang secara khusus dicetak untuk mengajar pada jenjang sekolah dasar. Masalah yang muncul, kompetensi 
mereka dalam seni musik pada umumnya kurang bahkan banyak yang tidak kompeten. Pada saat memasuki perguruan tinggi saja, mayoritas mahasiswa yang mengambil program studi PGSD tidak memiliki keterampilan memadai dalam bidang musik, seperti bernyanyi apalagi memainkan alat musik.

Tentu saja ini masalah yang pada dasarnya berkaitan dengan pendidikan musik di jenjang sekolah sebelumnya, termasuk pendalaman mereka sendiri pada dunia musik di luar sekolah formal. Artinya, ada di antara mereka yang mahir memainkan alat musik atau bernyanyi karena pengaruh lingkungan keluarganya yang notabene keluarga seniman, atau mereka yang memiliki hobi bermain musik sehingga membentuk band-band lokal di sekolahnya. Namun tentu saja kelompok yang minoritas ini tidak bisa menutupi kebutuhan guru musik di berbagai sekolah dasar, dan saat inilah dapat dilihat bagaimana hasil pendidikan musik di sekolah dasar yang bertumpu pada guru kelas sebagai pengajar musik.

\section{3) Guru Asal SMK Musik}

Guru musik dari kategori ini merupakan guru musik yang pada dasarnya dipersiapkan untuk dapat bekerja secara mandiri melalui keterampilan bermusiknya, bukan dipersiapkan untuk mengajar di sekolah-sekolah. Maka lazimnya bagi guru kategori ini prioritas utama pekerjaan adalah sebagai seniman murni yang hidupnya disandarkan pada aktivitas manggung, bukan pada aktivitas mengajar di sekolah. Oleh karena itu, perhatian terhadap kompetensi dasar dan evaluasi yang autentik terhadap semua perkembangan peserta didik pun pada umumnya relatif rendah.

\section{4) Guru Asal Sekolah Tinggi Seni}

Guru kategori ini merupakan guru yang pada dasarnya dipersiapkan untuk menjadi seniman murni yang siap untuk bekerja dan berkarya melalui keterampilan bermusiknya, bukan dipersiapkan untuk menjadi pengajar. Namun pada kenyataannya 
banyak lulusan sekolah tinggi seni yang pada akhirnya bekerja sebagai guru seni di sekolah-sekolah. Maka dari itu, bagi sebagian kalangan ada yang menempuh kuliah lagi untuk mendapatkan Akta IV, sebagai syarat untuk menjadi pengajar. Pembelajaran seni oleh guru kategori ini bisa sangat bagus jika pembelajaran seni diprioritaskan dan mengacu pada kurikulum beserta evaluasinya yang autentik, karena memang mereka ahli dalam bidangnya.

Namun ada pula kesamaan pola dengan guru asal SMK, dimana sebagian kalangan tidak menjadikan kegiatan mengajar sebagai prioritas utama, tapi sebagai sampingan, sehingga perhatian terhadap tujuan pembelajaran pun senantiasa terabaikan. Bahkan seringkali di sekolah-sekolah yang tidak memiliki guru seni, mendatangkan para seniman asal sekolah tinggi seni untuk melatih kesenian dalam event tahunan seperti saat perpisahan atau pembagian raport. Fenomena ini menyiratkan bahwa pembelajaran seni yang serius dan dilakukan oleh ahlinya hanya perlu dilakukan setahun sekali, sementara dalam pembelajaran sehari-hari cenderung diabaikan dan kembali ke kondisi semula, yakni menggunakan guru seni 'seadanya'.

\section{5) Guru Asal Pendidikan Seni Musik}

Guru kategori ini merupakan guru yang memang dipersiapkan untuk menjadi pengajar di sekolah-sekolah, karena dalam perkuliahan senantiasa dibekali dengan ilmu musik dan ilmu pedagogik. Kendatipun demikian, kalangan ini bukan berarti tidak memiliki masalah dalam implementasi pembelajaran di sekolah, justru banyak pula yang masih kebingungan untuk mengaplikasikan kemampuannya yang mesti dikorelasikan dengan penjabaran kurikulum sekolah dasar.

Masalah ini setidaknya teridentifikasi berpangkal pada tiga hal. Pertama, dimulai pada masa kuliahnya yang cenderung menghabiskan waktu untuk melatih skill pribadinya tanpa diimbangi dengan pemahaman terhadap ilmu pedagogiknya yang justru mengkaji bagaimana keterampilannya itu harus diajarkan. 
Kedua, arahan ilmu pedagogik pada perkuliahan yang terkadang kurang menukik pada jenjang sekolah tertentu, sehingga wawasan pada mahasiswa cenderung mengambang dan dangkal, sementara setiap jenjang sekolah memerlukan pendalaman dan pemahaman yang berbeda-beda karena dalam ilmu psikologi pun perkembangan dan karakter peserta didik notabene berbeda-beda pada setiap fase pertumbuhannya. Ketiga, terdapat kesamaan pola perilaku dengan tipe guru sebelumnya, yakni sebagian kalangan guru senantiasa menjadikan kegiatan mengajar sebagai prioritas kedua, karena lebih disibukan dengan aktivitas kesenimannya yaitu manggung sebagai bagian dari implementasi keterampilan dan pemenuhan kebutuhan hidup.

Ini sangat jelas berbeda dengan program studi PGSD, yang segala kegiatan perkuliahan memang dicurahkan untuk mengupas tuntas ihwal persoalan ke-SD-an, sehingga pengetahuan mahasiswa pun pada umumnya lebih mendalam mengenai jenjang sekolah tersebut. Oleh sebab itu, guru musik sekolah dasar asal prodi pendidikan musik kecenderungannya bisa menjadi sangat bagus dalam membelajarkan peserta didik, karena memang memiliki keahlian baik dalam ilmu musik maupun pedagogik, namun perlu waktu beradaptasi kembali untuk benar-benar menguasai medan pendidikan pada jenjang sekolah dasar.

\section{b. Solusi}

Berdasarkan pada analisis masalah di atas, maka setidaknya ada beberapa upaya perbaikan yang dapat dilakukan yakni sebagai berikut:

1) Guru musik di sekolah dasar seyogianya adalah guru yang terpisah dari guru kelas atau disebut sebagai guru bidang studi. Artinya yang mengajar musik bukanlah guru kelas yang serba bisa dan hanya belajar ilmu musik beberapa sks saja, tapi benar-benar guru yang spesialisasi atau kualifikasi akademiknya di bidang pendidikan musik. Dengan demikian, pada saat menghadapi peserta didik tidak lagi memikirkan materi apa yang harus diberikan 
karena serba tidak bisa, tapi lebih terfokus pada materi dan perlakuan apa saja yang mesti diberikan kepada peserta didik sesuai dengan kebutuhan dan tingkat perkembangan mereka yang juga mengacu pada tujuan pembelajaran yang ingin dicapai.

Bahkan telah ada hasil penelitian terdahulu mengenai penerapan sistem guru bidang studi di SD, seperti diteliti oleh Engkoswara (1976:86) dan mendapatkan temuan antara lain bahwa penerapan sistem guru bidang dibandingkan dengan sistem guru kelas di SD, mempengaruhi kemajuan rata-rata prestasi belajar murid-murid lebih baik dalam bidang bahasa Indonesia, IPA, IPS dan Matematika secara keseluruhan yang dievaluasi dengan ujian sekolah. Ini semakin meyakinkan asumsi bahwa penerapan guru bidang studi terhadap mata pelajaran musik pun dapat meningkatkan prestasi belajar dan mengembangkan perilaku baik pada peserta didik.

2) Pembenahan pada jalur pendidikan bagi calon guru musik sekolah dasar. Adanya program studi PGSD merupakan hal yang tepat untuk mencetak calon-calon guru di jenjang sekolah dasar, karena pembelajaran lebih terfokus pada satu jenjang sekolah saja, sehingga sangat memungkinkan lulusannya memahami secara mendalam persoalan ke-SD-an, setidaknya melalui proses pembelajaran di kelas, praktek lapangan dan penelitian tindakan kelas yang semuanya di lakukan pada jenjang sekolah dasar. Namun demikian, salahsatu kelemahannya adalah kurang mampu mencetak lulusan yang mahir dalam seni musik, karena untuk menjadi mahir dalam musik tidak cukup hanya dengan belajar melalui perkuliahan saja yang notabene pertemuannya sangat terbatas. Oleh karena itu, salahsatu upaya yang dapat dilakukan adalah dibukanya program studi PGSD guru musik, minimal dari mulai diploma tiga sampai strata satu, sehingga untuk ke depannya guru yang mengajar musik di sekolah dasar adalah guru yang memang dibekali keterampilan musik dan ilmu pedagogik secara memadai. Sementara ini yang telah tersedia baru PGSD guru kelas dan PGSD guru penjas, jadi tidak menutup kemungkinan dibuka lagi PGSD guru bidang studi lainnya. 
Adalah benar bahwa sekarang pada umumnya di program studi PGSD sudah ada spesialisasi bidang studi, seperti bahasa Indonesia, matematika, IPA, IPS, dan SBK, sehingga mahasiswa bisa mempelajari materi atau konsep-konsep keilmuannya secara mendalam. Namun yang perlu diingat, tetap saja mereka dicetak sebagai guru kelas yang pada saat di lapangan atau pada saat mengajar di sekolah dasar akan berperan sebagai guru yang mengajar berbagai mata pelajaran yang ironinya seperti disebutkan tadi dibagi-bagi ke dalam spesialisasi bidang studi. Akibatnya, jangankan setelah lulus, pada saat praktek lapangan saja biasa muncul persoalan bahwa mahasiswa yang spesialisasinya di bidang IPA, kesulitan mengajar di bidang matematika, atau sebaliknya, dan begitu pula dengan bidang-bidang lainnya.

Dapat dikatakan bahwa pembelajaran pada jenjang sekolah dasar bersifat mendasar, namun tidak berarti bahwa materinya dapat dianggap enteng dan semua guru kelas mampu menguasai semua mata pelajaran secara mendalam. Karena pada kenyataannya semua mata pelajaran memerlukan perhatian khusus dan pengkajian secara kontinyu demi perbaikan proses pembelajaran dan tercapainya tujuan pembelajaran, sehingga dilakukanlah penelitian tindakan kelas dan program lesson study sebagai bukti bahwa setiap bidang studi memiliki masalah tersendiri yang perlu dipecahkan melalui cara-cara tersendiri pula, dan memang proses seperti itulah yang dapat mencerminkan bahwa terjadi proses pembelajaran yang serius. Maka dari itu, sepertinya timbul keraguan apabila guru kelas dikatakan mampu memecahkan semua persoalan pembelajaran pada semua bidang studi yang diajarkan di kelas.

Seperti beberapa contoh penelitian berikut, yang membuktikan bahwa setiap bidang studi memiliki masalah tersendiri. Pertama, Wina Sanjaya (2002) yang mengutarakan bahwa rendahnya kualitas pembelajaran seperti yang banyak dikritik, terjadi pada setiap mata pelajaran termasuk mata pelajaran IPS yang pada tingkat sekolah dasar mulai diberikan di kelas 3 . Oleh sebab itu ia 
melakukan penelitian sebagai upaya meningkatkan kualitas pembelajaran dalam bidang IPS. Kedua, Fransiska S. Tapilouw (1997) yang menemukan masalah dalam bidang IPA sehingga melakukan penelitian tentang kreativitas berpikir anak usia sekolah dasar dalam memecahkan masalah-masalah IPA, dan menemukan bahwa kreativitas berpikir untuk kelas 3, kelas 4, dan kelas 6 SD berada pada rentang kreativitas rendah sampai sedang; kelas 5 berada pada rentang sedang sampai tinggi. Ketiga, Dalman None (2007) yang menemukan masalah rendahnya kemampuan siswa SD dalam membaca pemahaman untuk memahami informasi fokus teks bacaan, sehingga ia melakukan penelitian untuk memperbaiki kondisi tersebut. Keempat, lsrok'atun (2011) yang menyoroti masalah guru SD yang pada umumnya belum memahami konsepkonsep geometri secara benar, sehingga dilakukan penelitian dalam masalah tersebut. Kelima, Diana Rusmawati \& Endah Kumala Dewi (2011) yang berupaya untuk melakukan terapi musik dan gerak untuk mengatasi kesulitan berperilaku pada siswa sekolah dasar dengan gangguan ADHD.

Melihat berbagai masalah di atas yang merupakan bagian kecil saja dari masalah-masalah yang tersedia di sekolah dasar, bisa jadi memunculkan pertanyaan besar, apakah seorang guru kelas mampu mengatasi semua masalah pembelajaran yang ada dalam setiap bidang studi atau mata pelajaran? Kiranya tersedia jawaban yang secara logis dapat menjelaskan kondisi tersebut. Begitu pula dengan guru musik yang juga sebagai guru kelas, alangkah repotnya jika berniat untuk menciptakan pembelajaran yang serius, mulai dari menjabarkan kurikulum sampai pada implementasi pembelajarannya.

\section{Kesimpulan}

Berdasarkan pemaparan di atas, dapat diambil kesimpulan sebagai berikut: Pertama, sistem pendidikan sekolah dasar dengan menerapkan guru kelas dinilai kurang berkualitas karena setiap bidang studi memerlukan pengkajian yang mendalam dan kontinyu 
untuk memperoleh hasil pembelajaran yang maksimal dan memuaskan. Kasus ini terjadi pada ranah seni musik, namun tidak menutup kemungkinan fenomena yang sama juga berlaku untuk bidang studi lainnya, karena dapat dipastikan setiap bidang studi punya masalah yang mesti dipecahkan oleh guru yang ahli di bidangnya. Masalah akan selalu ada dan tampak ke permukaan selama pembelajaran dikaji dan dicermati oleh ahlinya, namun masalah akan ada dan tidak muncul ke permukaan jika pembelajaran dilakukan oleh guru yang bukan ahli dibidangnya, karena seorang ahli senantiasa peduli pada peserta didiknya sehingga akan berusaha mengkaji dan mencari pemecahan untuk berbagai masalah pembelajaran yang dilihatnya, sementara guru yang bukan ahli dibidangnya senantiasa kurang peduli terhadap persoalan pembelajaran yang ada dihadapannya, karena pada saat datang kepedulian pun pada umumnya kebingungan harus berbuat apa. Seperti guru kelas yang kebingungan pada saat mengajar musik, karena tidak menguasai materi, sehingga pada akhirnya musik pun tidak diajarkan dan dialihkan pada bidang seni lainnya.

Kedua, untuk memperoleh hasil belajar yang maksimal, seyogianya diberlakukan sistem guru bidang studi khususnya untuk bidang musik di sekolah dasar, sehingga memicu dibukanya program studi PGSD guru musik, dan dikembangkannya kurikulum pada jurusan pendidikan seni musik, seperti dibuatnya pendalaman ilmu pedagogik khusus untuk jenjang sekolah dasar, sekolah menengah pertama dan sekolah menengah atas, atau bisa jadi dibuat seperti pilihan konsentrasi khusus dalam ilmu pendidikan untuk memperoleh pemahaman yang lebih mendalam. Dengan demikian, dapat diperoleh kejelasan perihal calon guru yang sebenarnya memiliki kompetensi profesional atau sesuai untuk mengajar pada jenjang sekolah dasar.

\section{Daftar Pustaka}

Djailani. (1997). Profil Pembinaan Kemampuan Profesional Guru Pada Gugus SD Inti Kotamadya Banda Aceh: Studi Tentang 
Efektifitas Pemberdayaan Guru, Pengembangan Sekolah Sebagai Organisasi Belajar, dan Penataan Manajemen Sumber Daya Pendidikan. (Disertasi, Universitas Pendidikan Indonesia, 1997).

Diambil dari

http://digilib.upi.edu/digitalview.php?digital id=1376.

Djohan. (2003). Psikologi Musik. Yogyakarta. Buku Baik. Hartono. (2007). Kemampuan Guru SD/Ml dalam Menterjemahkan Mata Pelajaran (SBK) Seni Budaya dan Kerajinan (The Ability of Elementary School Teacher in Translating Art Culture and Craft Subject). Harmonia Jurnal Pengetahuan dan Pemikiran Seni, Vol VIIl No. 2, p. 100-105. Diambil dari

http://journal.unnes.ac.id/nju/index.php/harmonia/article/view/78

$2 / 714$.

None, Dalman. (2007). Kemampuan Memahami Informasi Fokus Terhadap Teks Bacaan Buku Ajar Bahasa Indonesia: Studi Pedalaman Bahasa dan Pemberlakuan Model Membaca Total di Kelas V SD di Kalijero Lampung Tengah (Disertasi, Universitas Pendidikan Indonesia, 2007). Diambil dari http://digilib.upi.edu/digitalview.php?digital_id=1165.

Sanjaya, Wina. (2002). Pengembangan Model Pembelajaran Metode Klinis Bagi Peningkatan Kemampuan Berpikir Siswa dalam Pembelajaran IPS di SD (Disertasi, Universitas Pendidikan Indonesia, 2002). Diambil dari http://digilib.upi.edu/digitalview.php?digital id=1421.

Tapilouw, S. Fransiska. (1997). Kreativitas Berpikir Anak Usia Sekolah Dasar dalam Memecahkan Masalah-Masalah IPA, Studi Kasus Pada SD Swasta di Bandung, Garut, dan Kuningan (Disertasi, Universitas Pendidikan Indonesia, 1997). Diambil dari http://digilib.upi.edu/digitalview.php?digital id=1270.

Wahyudi. (2010). Standar Kompetensi Profesional Guru. Jurnal Pendidikan Sosiologi dan Humaniora, Vol. 1. No. 2. Oktober 2010, p. 107-119. http://jurnal.untan.ac.id index.php/JPSH/article/download/385/388. 
Pendidikan Musik: Permasalahan dan Pembelajarannya

Zulfahmi, Nuri Sidauruk \& Zainuddin. (2013). Pemanfaatan Alat Musik Rekorder Sopran di Kelas Tinggi SD Swasta Terakreditasi "A" Kota Pontianak. Jurnal Pendidikan dan Pembelajaran, Vol 2 No. 6 Juni 2013. http://jurnal.untan.ac.id/index.php/jpdpb /article/view/2242/2197. 


\section{Bab5}

\section{STRATEG PENDIDIKAN MUSIK: TANAMKAN KEMAMPUAN BERPIKIR KRITIS}

\section{Pendahuluan}

Kemampuan berpikir kritis, yang diartikan Schafersman (Mustaji, 2009) sebagai berpikir yang benar dalam rangka mengetahui secara relevan dan reliabel tentang dunia - memang diperlukan dalam berbagai bidang ilmu, termasuk di antaranya bidang musik. Di PGSD UPI Kampus Sumedang misalnya, kemampuan berpikir kritis pada umumnya baru memperlihatkan arah yang baik pada jenis musik tertentu saja, terutama musikmusik yang berbau pop-modern. Sementara itu, hal yang memprihatinkan terjadi pada jenis musik-musik tradisional atau musik lokal. Ini terlihat pada berbagai aspek sebagai berikut: 1) wawasan kalangan mahasiswa pada umumnya terhadap seni tradisional masih rendah, 2) belum mampu memahami konsep musikal pada berbagai jenis musik tradisional, 3) penguasaan terhadap elemen-elemen musik masih rendah, 4) motivasi untuk belajar seni tradisional masih rendah, 5) keinginan untuk melihat berbagai pertunjukan seni tradisional masih rendah, dan 6) tidak memperlihatkan upaya yang baik untuk mencari dan bergabung dengan komunitas musik tradisional. Hanya sebagian kecil saja kalangan mahasiswa yang menunjukan ketercapaian terhadap berbagai aspek tersebut. Sebagai contohnya, dari sekitar 450 mahasiswa dari tingkat satu sampai tingkat tiga, hanya 25 mahasiswa yang memiliki pemahaman yang baik terhadap berbagai aspek di atas. Itu pun teridentifikasi karena mereka aktif dalam mengikuti berbagai kegiatan unit kegiatan mahasiswa dalam bidang seni, sehingga wawasan dan kemampuan musikalnya bertambah. 
Kelemahan yang terjadi pada beberapa aspek di atas merupakan akumulasi dari semua pelajaran musik yang dipelajari sejak dini baik di lingkungan formal maupun nonformal, karena untuk mencapai semua aspek tersebut diperlukan proses yang relatif panjang dan memerlukan pembelajaran musik yang berkelanjutan. Artinya, dalam setiap jenjang pendidikan perlu adanya substansi materi mata pelajaran musik yang terintegrasi, sehingga semuanya menuju pada titik-titik tertentu yang notabene sudah direncanakan secara menyeluruh, atau setidaknya termaktub dalam kurikulum secara terpadu. Sementara itu, apa yang terjadi sekarang, seperti dituturkan oleh mahasiswa tingkat satu, dari 190 mahasiswa, hanya 19 orang yang belajar musik pada jenjang sekolah dasar, sisanya belajar seni rupa. Dengan demikian, jangankan keterampilan musik, wawasan musik pun belum tentu mereka dapatkan. Akibatnya, ranah-ranah musik tradisi yang semestinya dekat dengan kehidupan mereka menjadi terlupakan, tidak dikenali, dianggap kampungan, dan sama sekali tidak terjalin hubungan psikologis dengan seni dan budaya setempat. Keterampilan musik yang mereka miliki hanya sebatas mendengarkan lagu-lagu band favorit mereka sambil ikut bernyanyi di tempat-tempat tertentu, atau beberapa orang memainkan instrumen gitar alakadarnya.

Melihat kondisi tersebut, memang berat rasanya untuk membentuk para calon pendidik musik sekolah dasar yang kompeten dan mampu berpikir kritis, karena sejak awal notabene tidak dibekali dengan keterampilan dan wawasan musik, sehingga pada taraf perguruan tinggi pun masih memprihatinkan. Oleh sebab itu, melalui tulisan ini akan dicoba disodorkan sebuah strategi pendidikan musik yang perlu dilakukan secara berjenjang untuk mencapai kemampuan berpikir kritis dalam musik. Strategi ini setidaknya dimulai diterapkan sejak pendidikan formal sekolah dasar sampai perguruan tinggi, sehingga perlu dipilah-pilah mana yang tepat diterapkan pada semua jenjang pendidikan tersebut. Harapannya, dengan menerapkan pembelajaran musik berbasis kemampuan berpikir kritis dapat menciptakan para peserta didik 
Julia

yang berwawasan musik lokal dan global, memiliki keterampilan musikal, serta senantiasa mengapresiasi, menghargai dan turut melestarikan musik-musik lokal.

\section{Berpikir Kritis dalam Musik}

Berpikir kritis tentu saja berbeda dari kegiatan berpikir manusia pada umumnya. Bailin, dkk (1999:287) merumuskan kegiatan berpikir kritis sebagai berikut.

critical thinking, as it is typically understood by educators, has at least these three features: it is done for the purpose of making up one's mind about what to believe or do; the person engaging in the thinking is trying to fulfill standards of adequacy and accuracy appropriate to the thinking; and the thinking fulfills the relevant standards to some threshold level.

Berdasarkan kutipan di atas kita dapat menemukan bahwa berpikir kritis mengisyaratkan kegiatan berpikir tingkat tinggi yang mengantarkan seseorang untuk mengetahui dengan pasti tentang apa yang harus diyakini dan dilakukannya dengan tepat. Tatkala berpikir kritis dilakukan dalam konteks pendidikan musik, maka semua pembelajaran mengarah pada berbagai aspek yang menuntun peserta didik untuk memiliki kemampuan berpikir kritis dalam koridor musik. Yang artinya bahwa peserta didik yang memiliki kemampuan berpikir kritis dalam musik senantiasa memperlihatkan dirinya untuk selalu terkoneksi dengan konteks dan konten musik. Maka dari itu, diperlukan strategi pembelajaran musik yang dapat memacu dan menstimulasi peserta didik untuk mencapai sejumlah sasaran kemampuan berpikir kritis.

Bessom, Tatarunis \& Forcucci (Gunara, 2008:8-10) merumuskan bahwa sasaran perubahan perilaku berpikir kritis dalam musik meliputi: 1) pengetahuan, 2) pemahaman, 3) keterampilan, 4) sikap, 5) apresiasi, dan 6) kebiasaan. Keenam sasaran tersebut dijabarkan lebih lanjut ke dalam beberapa indikator sebagai berikut. 


\begin{tabular}{|c|c|}
\hline $\begin{array}{l}\text { Sasaran } \\
\text { Belajar }\end{array}$ & Kemampuan Musikal \\
\hline Pengetahuan & $\begin{array}{l}\text { - Mengenal bermacam-macam karya musik, } \\
\text { atau yang mewakili dari semua macam- } \\
\text { macam karya musik. } \\
\text { - Mengetahui tentang sejarah dan } \\
\text { perkembangan artistik musik, termasuk } \\
\text { implikasi sosial, gaya musikal, dan sebagainya. } \\
\text { - Mempunyai pengetahuan tentang komponis } \\
\text { dan komposisinya yang dihubungkan dengan } \\
\text { perkembangan musik. } \\
\text { - Mempunyai pengetahuan gaya musikal } \\
\text { berdasarkan konteks sosialnya. }\end{array}$ \\
\hline Pemahaman & $\begin{array}{l}\text { - Memahami/merasakan konsep musikal yang } \\
\text { dihubungkan dengan bunyi musikal dan } \\
\text { penotasian (simbol). } \\
\text { - Mengenal perbedaan kriteria yang digunakan } \\
\text { untuk menggambarkan dan menilai beberapa } \\
\text { gaya musik, dan memahami permasalahan } \\
\text { penyajian yang meliputi interpretasi musik, } \\
\text { instrument, kombinasi instrumental, vokal } \\
\text { atau kombinasi vokal. } \\
\text { - Memahami hubungan lain antara musik } \\
\text { dengan seni lainnya. }\end{array}$ \\
\hline Keterampilan & $\begin{array}{l}\text { - Mempunyai keterampilan mengenal secara } \\
\text { aural dan visual elemen-elemen musik, } \\
\text { kemudian dapat mengaplikasikannya ketika } \\
\text { mendengar karya musik yang lain baik yang } \\
\text { dikenal atau tidak dikenal. } \\
\text { - Mempunyai kecakapan dan kebebasan untuk } \\
\text { berekspresi secara musikal, secara individual } \\
\text { atau berkelompok, melalui vokal atau } \\
\text { instrument, atau melalui karya musik. } \\
\text { - Bereksperimen dengan interpretasinya sendiri } \\
\text { melalui eksplorasi bunyi. }\end{array}$ \\
\hline Sikap & \begin{tabular}{|l} 
- Mempunyai kesadaran dalam membedakan \\
'rasa' musik dan perhatian terhadap
\end{tabular} \\
\hline
\end{tabular}




\begin{tabular}{|c|c|}
\hline & 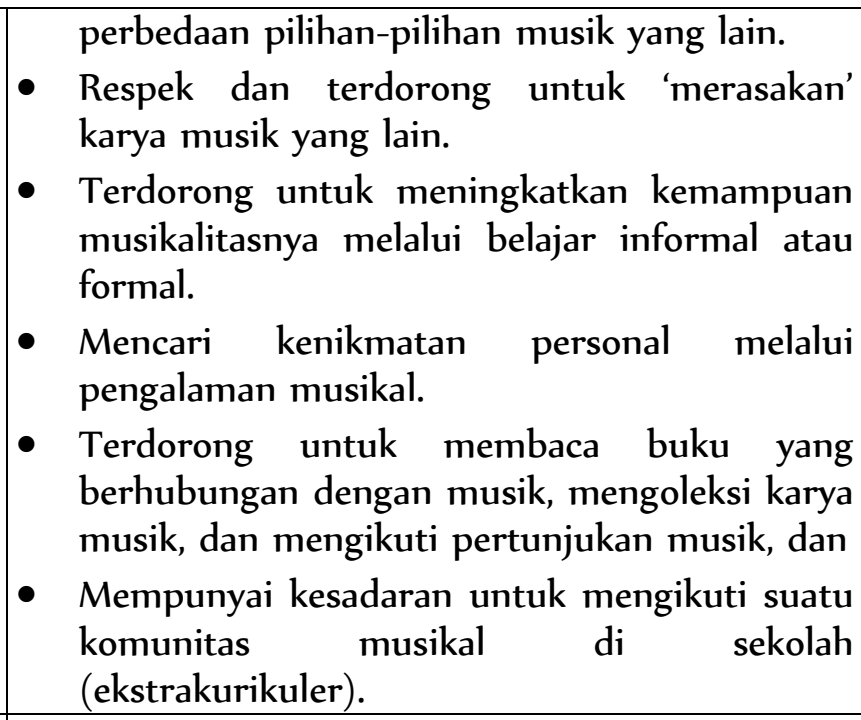 \\
\hline Apresiasi & $\begin{array}{l}\text { - Mempunyai kesadaran untuk lebih merasakan } \\
\text { aspek musikal. } \\
\text { - Respek terhadap pertunjukan musikal dan } \\
\text { seni lainnya. }\end{array}$ \\
\hline Kebiasaan & $\begin{array}{l}\text { - Adanya keinginan mencari komunitas musik } \\
\text { untuk bermain musik atau bernyanyi. } \\
\text { - Mengembangkan kebiasaan dan berlatih yang } \\
\text { baik. } \\
\text { - Selektif terhadap kualitas berbagai } \\
\text { pertunjukan musik, selektif dalam mengoleksi } \\
\text { karya musik, selektif ketika akan hadir dalam } \\
\text { suatu pertunjukan musik dan ketika } \\
\text { mendengarkan musik, dan } \\
\text { - Mendengarkan semua jenis musik dengan } \\
\text { melihat perbedaan interpretasi, kualitas bunyi, } \\
\text { kecermatan dan sebagainya. }\end{array}$ \\
\hline
\end{tabular}

Sumber: Gunara, 2008:9-10 (diadaptasi dari Bessom, Tatarunis \& Forcucci, 1974)

Semua aspek beserta indikator di atas dapat diimplementasikan di sekolah sesuai dengan perkembangan musikal peserta didik dari sisi perkembangan psikologis peserta didik. Maka dari itu, perlu 
dipilih dan dipilah indikator apa saja yang cocok diterapkan pada setiap jenjang pendidikan. Targetnya adalah semua indikator dapat tercapai setidaknya pada saat peserta didik berada pada jenjang perguruan tinggi.

\section{Strategi Pendidikan Musik}

Penerapan kemampuan berpikir kritis dalam musik, seyogianya dimulai secara formal dari mulai jenjang sekolah dasar sampai perguruan tinggi. Sasaran belajarnya terdiri atas enam aspek seperti telah disebutkan terdahulu, yakni aspek pengetahuan, pemahaman, keterampilan, sikap, apresiasi dan kebiasaan. Namun dalam proses penerapannya tidak dapat dilakukan sekaligus pada semua jenjang, karena setiap jenjang pendidikan memiliki tingkat kesulitan tersendiri yang berkorelasi dengan tingkat perkembangan peserta didik, baik secara motorik, kognitif atau afektif. Maka dari itu, diperlukan pemetaan indikator yang terdapat pada semua aspek kemampuan berpikir kritis terhadap jenjang-jenjang pendidikan. Berdasarkan pada pertimbangan perkembangan peserta didik yang dilihat dari aspek psikologi musik, maka indikatorindikator tersebut dapat dipetakan sebagai berikut.

Tabel 1. Aspek Pengetahuan

\begin{tabular}{|c|c|c|c|c|}
\hline \multicolumn{5}{|c|}{ Aspek Pengetahuan } \\
\hline & 1 & 2 & 3 & 4 \\
\hline $\begin{array}{l}\stackrel{5}{0} \\
\frac{\pi}{0} \\
\text { 章 } \\
\underline{\underline{E}}\end{array}$ & $\begin{array}{l}\text { Mengenal } \\
\text { bermacam- } \\
\text { macam karya } \\
\text { musik, atau } \\
\text { yang mewakili } \\
\text { dari semua } \\
\text { macam- } \\
\text { macam karya } \\
\text { musik }\end{array}$ & $\begin{array}{l}\text { Mengetahui } \\
\text { tentang } \\
\text { sejarah dan } \\
\text { perkembangan } \\
\text { artistik musik, } \\
\text { termasuk } \\
\text { implikasi } \\
\text { sosial, gaya } \\
\text { musikal, dan } \\
\text { sebagainya }\end{array}$ & $\begin{array}{l}\text { Mempunyai } \\
\text { pengetahuan } \\
\text { tentang } \\
\text { komponis dan } \\
\text { komposisinya } \\
\text { yang } \\
\text { dihubungkan } \\
\text { dengan } \\
\text { perkembangan } \\
\text { musik }\end{array}$ & $\begin{array}{l}\text { Mempunyai } \\
\text { pengetahuan } \\
\text { gaya musikal } \\
\text { berdasarkan } \\
\text { konteks } \\
\text { sosialnya }\end{array}$ \\
\hline
\end{tabular}




\begin{tabular}{|c|c|c|c|c|}
\hline 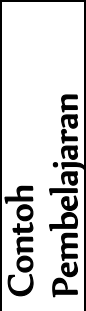 & $\begin{array}{l}\text { - Pembelajara } \\
\text { n melalui } \\
\text { media } \\
\text { Audio-Video } \\
\text { - } \text { Wisata seni }\end{array}$ & 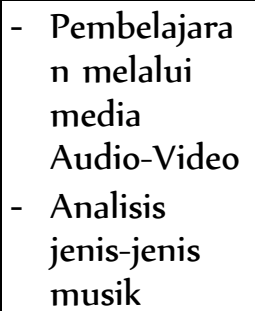 & 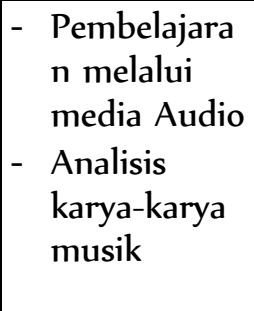 & 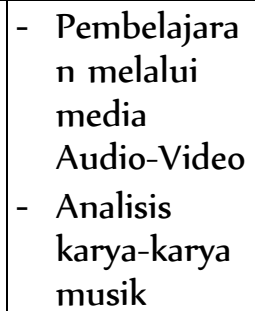 \\
\hline أ & $\begin{array}{l}\text { lndikator ke } \\
\text { lndikator kee }\end{array}$ & ka & igkat PT. & $\begin{array}{l}\text { PI PI; } \\
\text { ר PT; }\end{array}$ \\
\hline
\end{tabular}

Tabel 2. Aspek Pemahaman

\begin{tabular}{|c|c|c|c|}
\hline \multicolumn{4}{|c|}{ Aspek Pemahaman } \\
\hline & 1 & 2 & 3 \\
\hline 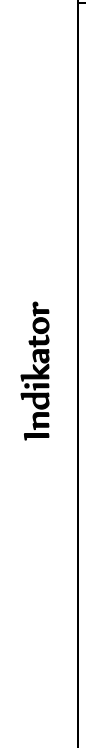 & $\begin{array}{l}\text { Memahami/merasakan } \\
\text { konsep musikal yang } \\
\text { dihubungkan dengan } \\
\text { bunyi musikal dan } \\
\text { penotasian (simbol). }\end{array}$ & $\begin{array}{l}\text { Mengenal } \\
\text { perbedaan kriteria } \\
\text { yang digunakan } \\
\text { untuk } \\
\text { menggambarkan } \\
\text { dan menilai } \\
\text { beberapa gaya } \\
\text { musik, dan } \\
\text { memahami } \\
\text { permasalahan } \\
\text { penyajian yang } \\
\text { meliputi interpretasi } \\
\text { musik, instrument, } \\
\text { kombinasi } \\
\text { instrumental, vokal } \\
\text { atau kombinasi } \\
\text { vokal. }\end{array}$ & $\begin{array}{l}\text { Memahami } \\
\text { hubungan lain } \\
\text { antara musik } \\
\text { dengan seni } \\
\text { lainnya. }\end{array}$ \\
\hline م & $\begin{array}{l}\text { - Pembelajaran } \\
\text { melalui media } \\
\text { Audio-Video } \\
\text { - } \\
\text { Analisis karya } \\
\text { musik }\end{array}$ & $\begin{array}{ll}\text { - } & \text { Pembelajaran } \\
& \text { melalui media } \\
& \text { Audio-Video } \\
\text { - } & \text { Analisis karya } \\
& \text { musik }\end{array}$ & $\begin{array}{ll}\text { - } & \text { Pembelajaran } \\
& \text { melalui media } \\
& \text { Audio-Video } \\
\text { - } & \text { Analisis karya } \\
& \text { musik }\end{array}$ \\
\hline
\end{tabular}




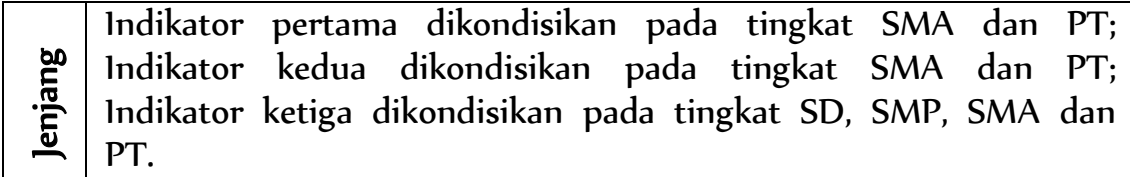

Tabel 3. Aspek Keterampilan

\begin{tabular}{|c|c|c|c|}
\hline \multicolumn{4}{|c|}{ Aspek Keterampilan } \\
\hline & 1 & 2 & 3 \\
\hline 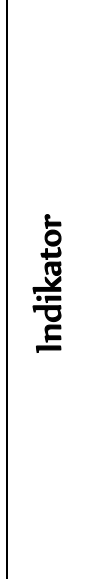 & $\begin{array}{l}\text { Mempunyai } \\
\text { keterampilan } \\
\text { mengenal secara } \\
\text { aural dan visual } \\
\text { elemen-elemen } \\
\text { musik, kemudian } \\
\text { dapat } \\
\text { mengaplikasikannya } \\
\text { ketika mendengar } \\
\text { karya musik yang } \\
\text { lain baik yang } \\
\text { dikenal atau tidak } \\
\text { dikenal. }\end{array}$ & $\begin{array}{l}\text { Mempunyai } \\
\text { kecakapan dan } \\
\text { kebebasan untuk } \\
\text { berekspresi secara } \\
\text { musikal, secara } \\
\text { individual atau } \\
\text { berkelompok, melalui } \\
\text { vokal atau } \\
\text { instrument, atau } \\
\text { melalui karya musik. }\end{array}$ & $\begin{array}{l}\text { Bereksperimen } \\
\text { dengan } \\
\text { interpretasinya } \\
\text { sendiri melalui } \\
\text { eksplorasi bunyi }\end{array}$ \\
\hline ن & $\begin{array}{l}\text { - Praktek bernyanyi } \\
\text { dan bermain } \\
\text { instrument musik }\end{array}$ & $\begin{array}{l}\text { - } \text { Praktek bernyanyi } \\
\text { dan bermain } \\
\text { instrument musik } \\
\text { - } \text { Membuat } \\
\text { komposisi musik }\end{array}$ & 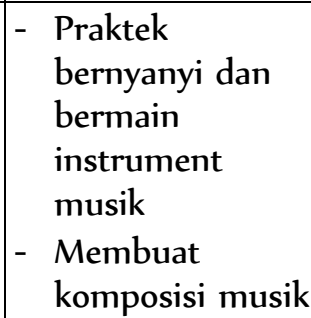 \\
\hline 窒 & \multicolumn{3}{|c|}{$\begin{array}{l}\text { Indikator pertama, kedua dan ketiga dikondisikan pada tingkat } \\
\text { SD, SMP, SMA dan PT }\end{array}$} \\
\hline
\end{tabular}


Tabel 4. Aspek Sikap

\begin{tabular}{|c|c|c|c|c|c|c|}
\hline \multicolumn{7}{|c|}{ Aspek Sikap } \\
\hline & 1 & 2 & 3 & 4 & 5 & 6 \\
\hline 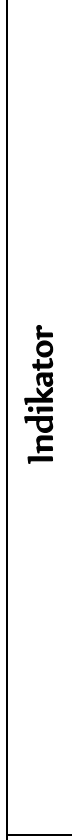 & $\begin{array}{l}\text { Mempuny } \\
\text { ai } \\
\text { kesadaran } \\
\text { dalam } \\
\text { membeda } \\
\text { kan 'rasa' } \\
\text { musik } \\
\text { dan } \\
\text { perhatian } \\
\text { terhadap } \\
\text { perbedaa } \\
\text { n pilihan- } \\
\text { pilihan } \\
\text { musik } \\
\text { yang lain. }\end{array}$ & \begin{tabular}{|l} 
Respek \\
dan \\
terdorong \\
untuk \\
'merasaka \\
n' karya \\
musik \\
yang lain.
\end{tabular} & \begin{tabular}{|l|} 
Terdoro \\
ng \\
untuk \\
meningk \\
atkan \\
kemamp \\
uan \\
musikali \\
tasnya \\
melalui \\
belajar \\
informal \\
atau \\
formal.
\end{tabular} & $\begin{array}{l}\text { Menca } \\
\text { ri } \\
\text { kenikm } \\
\text { atan } \\
\text { person } \\
\text { al } \\
\text { melalui } \\
\text { pengal } \\
\text { aman } \\
\text { musika } \\
\text { l. }\end{array}$ & \begin{tabular}{|l|} 
Terdoro \\
ng \\
untuk \\
membac \\
a buku \\
yang \\
berhubu \\
ngan \\
dengan \\
musik, \\
mengole \\
ksi karya \\
musik, \\
dan \\
mengiku \\
ti \\
pertunju \\
kan \\
musik. \\
\end{tabular} & $\begin{array}{l}\text { Mempun } \\
\text { yai } \\
\text { kesadara } \\
\mathrm{n} \text { untuk } \\
\text { mengiku } \\
\text { ti suatu } \\
\text { komunit } \\
\text { as } \\
\text { musikal } \\
\text { di } \\
\text { sekolah } \\
\text { (ekstrak } \\
\text { urikuler) } \\
\text {. }\end{array}$ \\
\hline 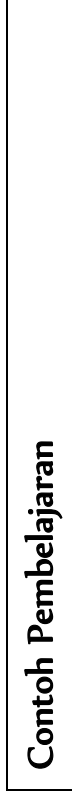 & 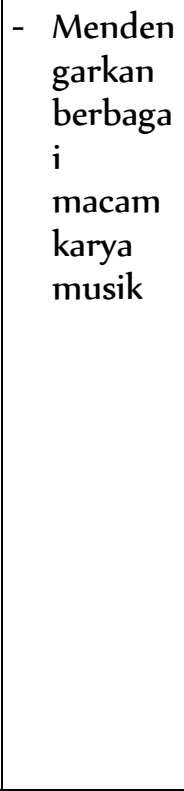 & 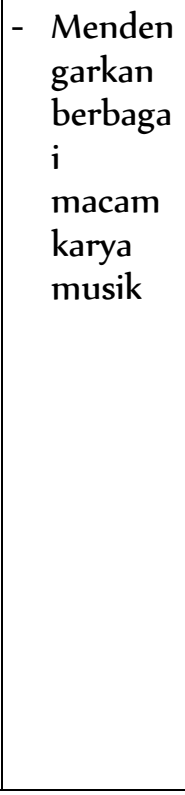 & $\begin{array}{cl}\text { - } & \text { Prakte } \\
\text { k alat } \\
\text { musik } \\
\text { dan } \\
\text { vokal }\end{array}$ & 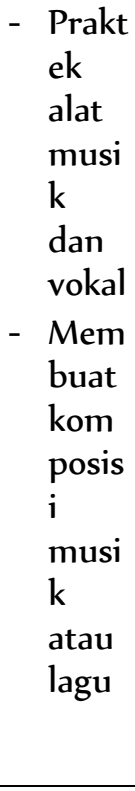 & 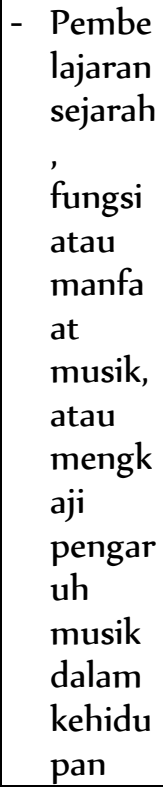 & $\begin{aligned} &- \text { Pembe } \\
& \text { lajaran } \\
& \text { berkel } \\
& \text { ompok } \\
& \text { memai } \\
& \text { nkan } \\
& \text { alat } \\
& \text { musik } \\
& \text { atau } \\
& \text { belajar } \\
& \text { padua } \\
& \text { n } \\
& \text { suara }\end{aligned}$ \\
\hline
\end{tabular}




\begin{tabular}{|c|c|}
\hline 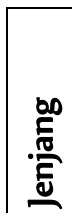 & $\begin{array}{l}\text { Indikator pertama dan kedua dikondisikan pada tingkat SMA dan } \\
\text { PT; Indikator ketiga dan keempat dikondisikan pada tingkat SD, } \\
\text { SMP, SMA dan PT; Indikator kelima dikondisikan pada tingkat } \\
\text { SMA dan PT; Indikator keenam dikondisikan pada tingkat SMP, } \\
\text { SMA dan PT }\end{array}$ \\
\hline
\end{tabular}

Tabel 5. Aspek Apresiasi

\begin{tabular}{|c|c|c|}
\hline \multicolumn{3}{|c|}{ Aspek Apresiasi } \\
\hline & 1 & 2 \\
\hline 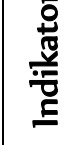 & $\begin{array}{l}\text { Mempunyai kesadaran untuk } \\
\text { lebih merasakan aspek } \\
\text { musikal. }\end{array}$ & $\begin{array}{l}\text { Respek terhadap pertunjukan } \\
\text { musikal dan seni lainnya. }\end{array}$ \\
\hline مَ & $\begin{array}{l}\text { - Mendengarkan berbagai } \\
\text { karya musik } \\
\text { - Menganalisis struktur musik } \\
\text { beserta unsur ekspresi atau } \\
\text { dinamikanya } \\
\text { - Membuat komposisi musik } \\
\text { atau lagu }\end{array}$ & $\begin{array}{ll}\text { - } & \text { Nonton berbagai pertunjukan } \\
\text { musik } \\
\text { - } \\
\text { Melakukan pertunjukan musik, } \\
\text { drama dan tari }\end{array}$ \\
\hline 䆓 & \multicolumn{2}{|c|}{$\begin{array}{l}\text { Indikator pertama dikondisikan pada tingkat SMA dan PT; } \\
\text { Indikator kedua dikondisikan pada tingkat SD, SMP dan SMA }\end{array}$} \\
\hline
\end{tabular}


Tabel 6. Aspek Kebiasaan

\begin{tabular}{|c|c|c|c|c|}
\hline \multicolumn{5}{|c|}{ Aspek Kebiasaan } \\
\hline & 1 & 2 & 3 & 4 \\
\hline 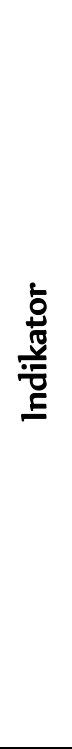 & $\begin{array}{l}\text { Adanya } \\
\text { keinginan } \\
\text { mencari } \\
\text { komunitas } \\
\text { musik untuk } \\
\text { bermain } \\
\text { musik atau } \\
\text { bernyanyi. }\end{array}$ & $\begin{array}{l}\text { Mengembangka } \\
\mathrm{n} \text { kebiasaan dan } \\
\text { berlatih yang } \\
\text { baik. }\end{array}$ & $\begin{array}{l}\text { Selektif } \\
\text { terhadap } \\
\text { kualitas } \\
\text { berbagai } \\
\text { pertunjukan } \\
\text { musik, selektif } \\
\text { dalam } \\
\text { mengoleksi } \\
\text { karya musik, } \\
\text { selektif ketika } \\
\text { akan hadir } \\
\text { dalam suatu } \\
\text { pertunjukan } \\
\text { musik dan } \\
\text { ketika } \\
\text { mendengarkan } \\
\text { musik }\end{array}$ & $\begin{array}{l}\text { Mendengarka } \\
\mathrm{n} \text { semua jenis } \\
\text { musik dengan } \\
\text { melihat } \\
\text { perbedaan } \\
\text { interpretasi, } \\
\text { kualitas } \\
\text { bunyi, } \\
\text { kecermatan } \\
\text { dan } \\
\text { sebagainya. }\end{array}$ \\
\hline 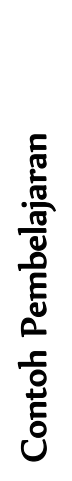 & $\begin{array}{l}\text { - Pembelajara } \\
\text { n } \\
\text { berkelompo } \\
\text { k seperti } \\
\text { gamelan } \\
\text { - Pembelajara } \\
\text { n paduan } \\
\text { suara }\end{array}$ & $\begin{array}{l}\text { - Melakukan } \\
\text { pertunjukan- } \\
\text { pertunjukan } \\
\text { musik } \\
\text { instrument } \\
\text { atau paduan } \\
\text { suara }\end{array}$ & 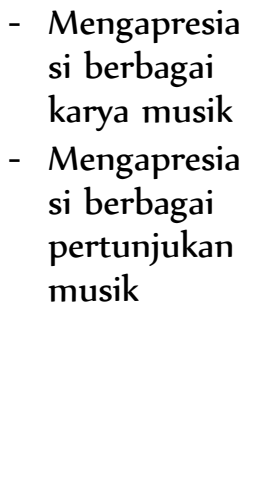 & $\begin{array}{l}\text { - Melakukan } \\
\text { analisis } \\
\text { musik } \\
\text { seperti } \\
\text { analisis } \\
\text { struktur, } \\
\text { ekspresi, } \\
\text { kualitas } \\
\text { bunyi, dan } \\
\text { jumlah alat } \\
\text { musik. }\end{array}$ \\
\hline 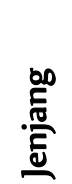 & $\begin{array}{l}\text { Indikator per } \\
\text { Indikator ked } \\
\text { Indikator ket } \\
\text { PT. }\end{array}$ & $\begin{array}{l}\text { dikondisikan } \\
\text { ikondisikan p } \\
\text { lan keempat }\end{array}$ & $\begin{array}{l}\text { da tingkat } S \Lambda \\
\text { tingkat SD, } S \\
\text { ddisikan pada }\end{array}$ & $\begin{array}{l}\text { SMA dan PT; } \\
\text { SMA dan PT; } \\
\text { gkat SMA dan }\end{array}$ \\
\hline
\end{tabular}

\section{Simpulan}

Berdasarkan paparan di atas, maka dapat disimpulkan bahwa untuk membentuk peserta didik yang mampu berpikir kritis dalam musik, diperlukan pengimplementasian dari keenam aspek berpikir 
kritis dalam musik yang tersebar melalui indikator-indikator berpikir kritis dan dimulai dari jenjang sekolah dasar sampai perguruan tinggi dengan menggunakan model-model pembelajaran yang bervariasi sesuai dengan keperluan indikator dari setiap aspeknya. Dapat dirumuskan bahwa setidaknya terdapat sembilan indikator yang perlu dikondisikan pada tingkat SD, 12 indikator pada tingkat SMP, 21 indikator pada tingkat SMA, dan 21 indikator pada tingkat PT. Semua indikator tesebut dapat terasah melalui pembelajaran musik yang variatif, seperti pembelajaran dengan menggunakan media audio-visual, pembelajaran berkelompok seperti bermain gamelan dan paduan suara, menganalisis karyakarya musik, membuat komposisi musik atau vokal, menonton puspa ragam pertunjukan musik, membuat pertunjukanpertunjukan musik sendiri, dan lain-lain. Jadi, pada dasarnya kemampuan berpikir kritis dalam musik terbentuk karena terkondisikan dalam jangka waktu yang relatif lama, sekurangkurangnya melalui pengasahan di setiap jenjang pendidikan. Dengan demikian, jika pada saat melalui berbagai jenjang pendidikan peserta didik tidak mendapatkan pengkondisian dari berbagai indikator di atas, apalagi sama sekali tidak diajarkan musik, maka dapat dipastikan kemampuan berpikir kritis dalam musik pun tidak akan terbangun.

\section{Referensi}

Bailin, Sharon. Dkk. (1999). Conceptualizing Critical Thinking. J. Curriculum Studies,1999, Vol. 31, No. 3, 285-302. Tersedia: www.ubc.ca/okanagan/ctl/_shared/assets/ctconceptualize597.pdf/.

Gunara, Sandi. (2008). Konsep Pembelajaran Musik di Sekolah Umum. Dalam Narawati, Milyartini \& Soeteja (Ed). (2010). Pendidikan Seni dan Perubahan Sosial Budaya. Bandung: Prodi Pendidikan Seni SPS UPI.

Mustaji. (2009). Pengembangan Kemampuan Berpikir Kritis dan Kreatif dalam Pembelajaran di Sekolah. Jurnal Pendidikan Dasar 
Julia

$\begin{array}{lllll}\text { Vol } & 5, & \text { No } & 5, & \text { (2009). }\end{array}$

http://ejournal.unesa.ac.id/index.php/jurnal wacana/article/view/5 $\underline{682}$ atau http://pasca.tp.ac.id/site/pengembangan-kemampuanberpikir-kritis-dan-kreatif-dalam-pembelajaran. 


\section{Bab 6}

\section{O)(EMBANGUN KERJASAMA KELOMPOK MELALUI PEMBELAJARAN ENSEMBLE ANGKLUNG PADA MAHASISWA PGSD}

\section{Pendahuluan}

Salah satu aspek penting yang perlu dikembangkan dalam proses pembelajaran adalah menumbuhkan ikatan psikologis antar peserta didik untuk membangun kerjasama kelompok. Kerjasama di sini dapat diartikan sebagai kegiatan atau usaha yg dilakukan oleh beberapa orang (lembaga, pemerintah, dsb) untuk mencapai tujuan bersama (kamusbesar.com, 2012). Banyak potensi-potensi bahan pembelajaran yang dapat dijadikan sebagai latihan memupuk rasa saling membutuhkan sebagai bagian dari kerjasama, seperti belajar berkelompok dengan tugas-tugas yang harus diselesaikan secara bersama-sama. Namun berdasarkan temuan-temuan di lapangan, seperti terjadi pada mahasiswa jurusan Pendidikan Guru Sekolah Dasar (PGSD) di Universitas Pendidikan Indonesia (UPI) Kampus Sumedang, ikatan kerjasama yang serius tidak benar-benar terbentuk dalam kelompok belajar. Temuan ini dapat dijabarkan ke dalam beberapa poin berikut. Pertama, materi belajar kelompok bebannya tidak terlalu berat atau tidak menuntut penyelesaian secara berkelompok sehingga pekerjaan dapat diselesaikan tanpa berkelompok atau oleh perwakilan kelompok saja. Kedua, materi belajar kelompok tidak menuntut peserta didik untuk selalu belajar bersama atau tidak menuntut kesatuan kelompok yang utuh sehingga tugas dapat diselesaikan di tempat masing-masing sesuai dengan pembagian tugas yang diterima. Ketiga, hasil dari kerja kelompok kurang merepresentasikan kemahiran dan keseriusan setiap anggota kelompok pada saat dilakukan presentasi kelompok. 
Dengan demikian, maksud dari bangunan kerjasamanya sendiri tidak tercapai seperti kesadaran dan kebiasaan untuk menyelesaikan permasalahan secara bersama-sama, bahkan hal urgen dan unik seperti tumbuhnya ikatan batin di antara sesama anggota kelompok masih jarang terjadi. Adapun ikatan batin yang terbentuk pada umumnya baru sebatas hubungan antara teman karib saja tidak terbentuk secara menyeluruh dengan teman-teman yang lainnya baik dalam kelompok maupun luar kelompok. Dengan kondisi demikian, makna belajar kerjasama akan luntur manakala mereka berada di dalam dunia nyata di luar konteks pendidikan formal. Padahal, landasan berpikir dalam konteks ini bahwa sekolah itu adalah kehidupan itu sendiri, sehingga - jika dalam kehidupan nyata kerjasama adalah bagian dari keseharian, maka di sekolahpun kerjasama mesti dijadikan kebiasaan dan merupakan bagian dari latihan pembiasaan untuk bekerjasama.

Untuk memberikan pembelajaran kepada mahasiswa ihwal makna kerjasama dan bagaimana cara membangunnya, maka praktek dalam pendidikan seni musik dapat menjadi salah satu alternatif yang dinilai tepat. Ini berdasarkan pada pertunjukan musik yang memiliki tuntutan untuk bekerjasama dengan serius demi mewujudkan suatu karya pertunjukan yang utuh. Dalam musik, konsep ini disebut sebagai permainan ensemble atau mempertunjukkan musik secara bersama-sama, atau dalam pendidikan pada umumnya konsep seperti ini disebut sebagai pembelajaran kooperatif (cooperative learning). Seperti dijelaskan dalam Wikipedia (2012) bahwa pembelajaran kooperatif atau cooperative learning merupakan istilah umum untuk sekumpulan strategi pengajaran yang dirancang untuk mendidik kerjasama kelompok dan interaksi antarsiswa.

Secara umum hampir semua jenis pertunjukan musik dilakukan dengan konsep ensemble, hanya sebagian kecil musik yang dipertunjukan secara solo atau sendiri, seperti konser piano tunggal. Di Jawa Barat, genre-genre seni tradisi pun banyak disajikan dengan konsep ensemble, seperti gamelan degung, 
tembang Cianjuran, angklung, dan lain-lain. Dalam kajian ini, salah satu genre musik yang dijadikan sebagai bahan pembelajaran di kelas adalah ensemble angklung. Hal ini berdasarkan pada pembelajaran angklung yang teknik permainannya relatif mudah namun menuntut kerjasama kelompok yang relatif tinggi, sehingga dapat dengan mudah diterapkan pada mahasiswa PGSD. Maka dari itu, pengkajian akan berputar di sekitar bagaimana mahasiswa mempelajari suatu karya angklung yang menuntut kerjasama kelompok sehingga terbentuk suatu karya yang utuh.

\section{Metode Penelitian}

Pengumpulan data dilakukan dengan cara observasi langsung terhadap tiga kelas mahasiswa dengan jumlah 142 orang yang terbagi ke dalam sembilan kelompok (satu kelas terdiri atas tiga kelompok) dan wawancara terhadap beberapa mahasiswa sebagai perwakilan dari beberapa kelompok yang dianggap mengetahui berbagai fenomena atau peristiwa yang terjadi di kelompoknya masing-masing pada saat melakukan proses latihan angklung. Oleh sebab itu, pengkajian dan penilaian pun bertumpu pada keterampilan proses. Sementara itu, peneliti selain berperan sebagai instrumen penelitian juga berperan sebagai participant observation.

Karya angklung yang dijadikan bahan pembelajaran adalah lagu berjudul "La Nuit" karya Jean-Phillippe Rameau (1683-1764) yang diaransemen oleh Nancy Grundahl untuk vokal tiga suara. Berhubung partitur utuh hasil aransemen Grundahl tidak ditemukan, maka pentranskripsian karya dilakukan oleh peneliti dari hasil mendengarkan audio, sehingga mungkin saja terdapat perbedaan dengan aransemen aslinya. Dalam penelitian ini karya tersebut ditransfer atau dimainkan oleh angklung dengan sedikit diaransemen kembali oleh peneliti untuk penyesuaian dengan karakter bunyi pada angklung, dan tetap dalam pola tiga suara. Pemilihan karya ini berdasarkan pada kompleksitas komposisinya yang memerlukan kerjasama serius dari para pemainnya, sehingga 
hipotesisnya, jika setiap kelompok mampu memainkan karya angklung dengan baik, maka kerjasama yang serius telah terbentuk dalam kelompok.

\section{Hasil dan Pembahasan}

Proses pembelajaran angklung yang dilakukan selama tujuh kali pertemuan (tujuh minggu) dalam perkuliahan, dapat dipaparkan sebagai berikut.

\section{Tahap Pengenalan Angklung}

Pada tahap ini, mahasiswa diberikan wawasan mengenai teknik bermain angklung dan membaca partitur angklung, sekaligus mencoba memainkan bagian awal karya angklung yang akan dijadikan sebagai bahan pembelajaran. Melalui cara ini, mereka menjadi paham bagaimana memainkan karya angklung yang komposisinya terdiri atas tekstur bunyi berurutan atau bunyi bersamaan beberapa nada. Pekerjaan mereka selanjutnya yang relatif sulit adalah memainkan karya angklung dengan kelompoknya masing-masing sampai setiap anggota kelompok hafal perbagian karya dan keseluruhan karya sehingga dapat memainkan karya angklung secara utuh tanpa melihat partitur. Di sinilah bangunan kerjasama setiap kelompok akan terlihat dengan jelas.

\section{Tahap Pembagian Kelompok}

Pada tahap ini mahasiswa dikelompokan secara random tanpa memperhatikan tingkatan kemampuan. Pemilihan anggota kelompok pun ditentukan oleh mereka sendiri dengan cara yang simple, yakni dibagi berdasarkan urutan absensi kelas. Namun karena jumlah mahasiswa laki-laki sedikit, yakni sekitar lima orang di tiap kelas, maka pemerataan dilakukan terhadap mahasiswa lakilaki untuk berada di setiap kelompok. Jumlah setiap kelompok disamaratakan sehingga relatif sama, ada sedikit perbedaan jumlah anggota kelompok yakni hanya berbeda satu orang, sehingga ada kelompok yang jumlahnya ganjil dan ada pula yang genap, disesuaikan dengan jumlah keseluruhan mahasiswa di tiap kelas. 


\section{Tahap Pembelajaran Angklung}

Pada tahap ini ada beberapa fase pembelajaran yang dilewati oleh semua kelompok, antara lain:

\section{a. Pembagian Jadwal Latihan}

Jadwal latihan dibuat bersama-sama oleh semua kelompok dengan maksud untuk membagi jadwal latihan secara adil karena perangkat angklungnya terbatas yaitu hanya terdapat satu set lengkap saja sehingga harus bergantian, dan juga karena mereka harus membagi waktu dan menyesuaikan dengan jadwal kegiatan lainnya. Dari jangka waktu yang diberikan yakni tujuh minggu, mereka sepakat bahwa dari minggu pertama sampai minggu keempat (satu bulan) latihan dilakukan sebanyak satu kali dalam seminggu (di luar perkuliahan angklung), dan dari minggu kelima sampai minggu ketujuh latihan dilakukan dua kali dalam seminggu.

\section{b. Latihan dengan Membaca Partitur Angklung}

Pada fase ini semua kelompok mempelajari partitur secara mendetail dengan kemampuan bermain sekitar satu baris partitur dalam satu kali latihan. Berdasarkan hasil pengamatan, mereka belajar dengan cara mempelajari partitur perbaris dan persuara dari suara satu, dua dan tiga. Artinya, jika pemain angklung dalam deretan suara pertama telah dinilai bagus, maka diteruskan dengan mempelajari angklung deretan suara dua, dan selanjutnya suara tiga. Jika semua deretan suara telah selesai, dilanjutkan dengan mencoba menggabungkan semua suara. Yang banyak dilakukan pengulangan adalah pada saat penggabungan tiga suara. Manakala ada bagian tertentu yang masih kacau karena ada anggota yang belum pas dalam memainkan angklungnya, maka mereka mengulangnya dari awal lagi, karena terkadang memulai dari pertengahan karya itu relatif sulit bagi mereka.

Berikut partitur lengkap dari lagu "La Nuit" versi angklung tiga suara. 
La Nuit

Jean-Phillippe Rameau (1683-1764) arranged by Nancy Grundah

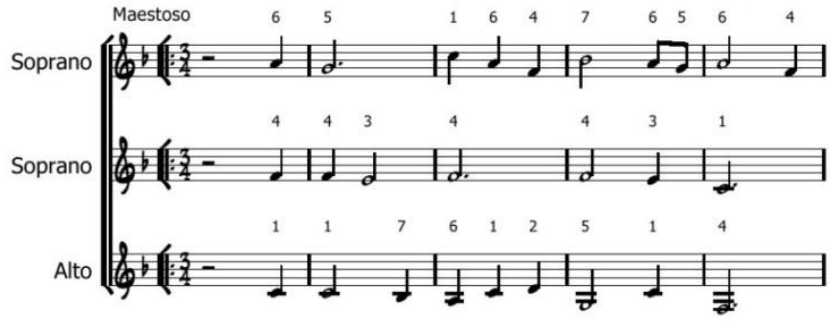

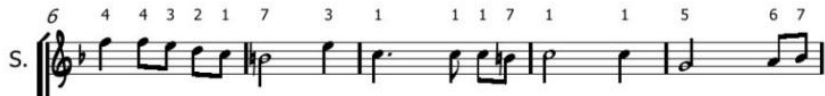
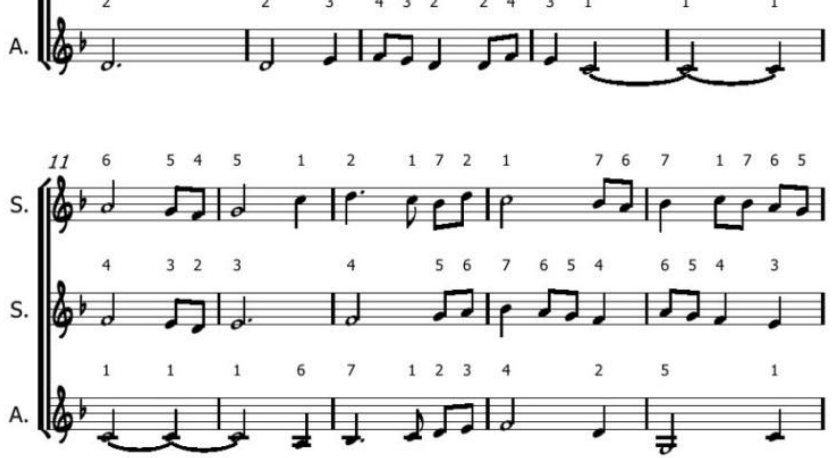

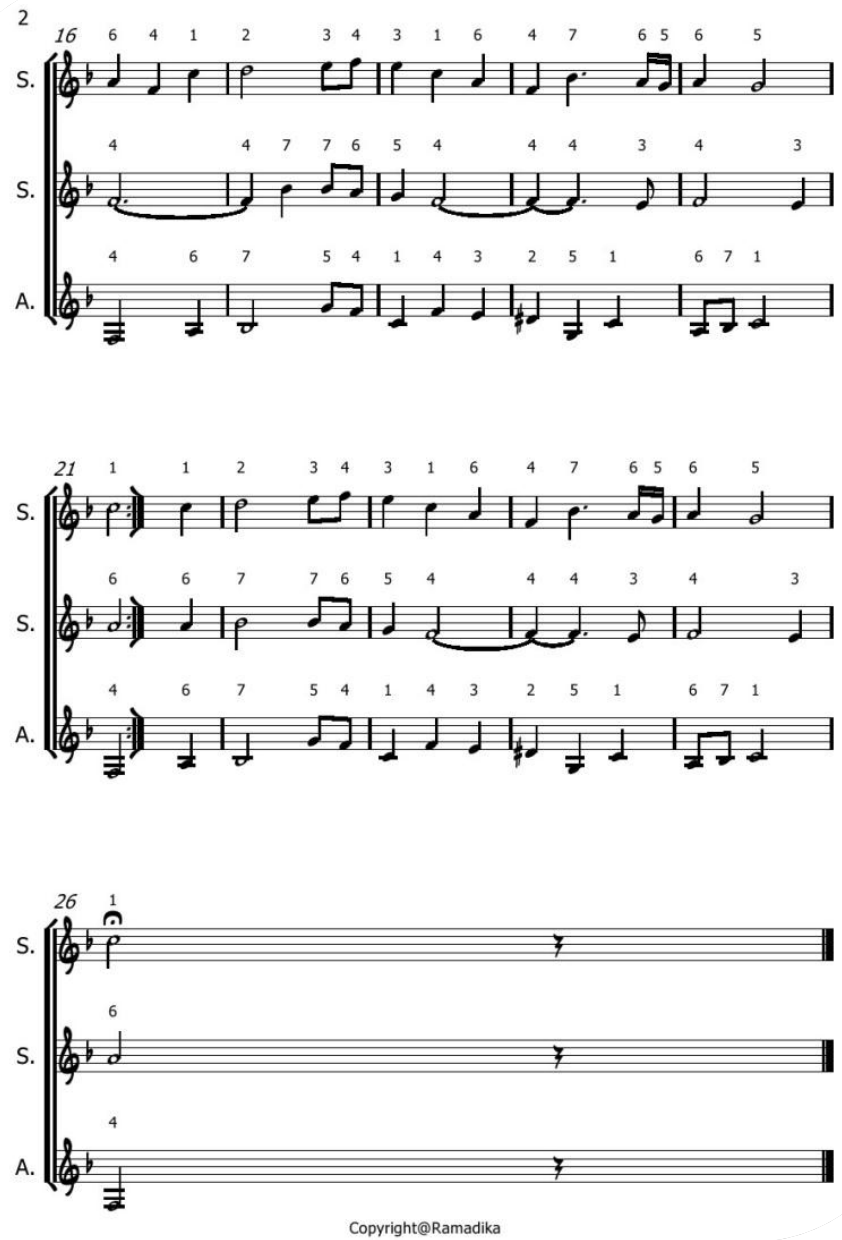

\section{Gambar 1. Partitur La Nuit}

\section{c. Latihan Tanpa Membaca Partitur Angklung}

Memasuki minggu kelima, semua kelompok diarahkan untuk mulai memainkan karya angklung tanpa melihat partitur. Proses ini cukup sulit, karena meskipun pada umumnya semua kelompok telah lancar memainkan keseluruhan karya, namun ketika lepas 
dari partitur seperti kembali lagi ke awal pembelajaran, yakni terjadi lagi kekacauan. Masalahnya, selama empat minggu pertama semua anggota kelompok dengan asyiknya memainkan angklung sambil melihat partitur, sehingga yang banyak berperan adalah kemampuan visualnya. Sementara untuk memainkan karya angklung tanpa melihat partitur, yang diperlukan adalah kemampuan auditif, karena pada prinsipnya seseorang memainkan suatu nada setelah mendengar nada yang lainnya, sehingga semua anggota harus hafal melodi lagu secara keseluruhan agar mereka tahu secara pasti kapan harus membunyikan angklung yang dipegangnya.

\section{d. Latihan Memberikan Sentuhan Ekspresi}

Pemberian ekspresi atau dinamika terhadap karya angklung diarahkan pada minggu keenam atau mendekati akhir pertemuan. Ini dilakukan karena sentuhan ekspresi lebih mudah diberikan setelah para pemain hafal terhadap tugas-tugas individu terutama hafal terhadap keseluruhan bentuk karya, sehingga tidak ada beban untuk menghafal lagi, tapi terfokus pada pemberian ekspresi. Dan terbukti cara ini dapat dengan cepat dilakukan oleh setiap kelompok, sehingga hasilnya karya angklung yang dimainkan oleh setiap kelompok terasa lebih bernyawa.

Pada tahap praktek pembelajaran angklung ini, masalah yang terjadi dalam kelompok tidak begitu mencuat kepermukaan terutama pada saat pertemuan dalam jam perkuliahan, yang terjadi adalah semua kelompok berupaya menampilkan yang terbaik. Namun lain halnya tatkala ditelusuri melalui wawancara dengan beberapa perwakilan kelompok, ternyata ada beberapa fenomena yang terjadi dalam proses mempelajari karya angklung tersebut. Hal itu dapat diakumulasikan ke dalam beberapa poin berikut. Pertama, frekuensi latihan. Terkait dengan jumlah latihan yang disepakati oleh semua kelompok, ada beberapa kelompok yang 
menambah jam latihan, terutama dari mulai minggu kelima sampai minggu ketujuh, sehingga dalam seminggu ada yang berlatih sampai tiga kali. Mereka memanfaatkan waktu luang untuk lebih menguasai karya angklung.

Kedua, kelengkapan anggota kelompok. Masalah yang muncul ketika melaksanakan proses latihan rutin yang terjadwal, adalah adanya anggota yang tidak hadir pada saat jadwal latihan yang telah disepakati bersama, dengan alasan ada kepentingan keluarga bahkan ada pula yang tanpa alasan, sehingga terkesan kurang bertanggung jawab terhadap tugas yang diberikan. Akibatnya, latihan pun terganggu karena komposisi permainan angklung menjadi tidak lengkap. Dengan adanya permasalahan ini, maka pada akhirnya muncul solusi dari kelompok yaitu: 1) anggota lainnya mencoba untuk menggantikan tugas anggota yang tidak hadir sehingga menjadi double peran, 2) melakukan peminjaman anggota antar kelompok sesuai dengan anggota yang dibutuhkan untuk melengkapi komposisi angklung.

Ketiga, perbedaan kecepatan belajar. Hal ini pun menjadi masalah bagi kelompok, karena di saat mereka ingin berlari kencang, namun terhalang oleh anggota lainnya yang hanya bisa berjalan kaki, sehingga pada akhirnya mereka mengalah untuk mencoba menunggu anggota lainnya sampai bisa mengejar ketertinggalan. Adapun tanggung jawab yang muncul dari mereka yang dipandang kurang cepat dalam belajar angklung, adalah mencoba untuk ikut berlatih dengan kelompok lainnya di luar jadwal latihan kelompoknya sendiri, sehingga mereka pun dapat mengejar ketertinggalan materi.

Keempat, sikap anggota kelompok. Karena beberapa masalah seperti disebutkan di atas, maka pada umumnya dalam kelompok pun bermunculan perbedaan pandangan yang berdampak pada pembawaan sikap setiap anggota kelompok. Misalnya, persoalan kehadiran dimana anggota yang tempat tinggalnya jauh dapat hadir dengan tepat waktu sementara anggota yang tempat tinggalnya dekat senantiasa datang terlambat, atau lebih parahnya anggota 
yang tidak hadir tanpa alasan, dan pada saat dihubungi, alat komunikasinya tidak aktif. Ini mengakibatkan munculnya masalah internal dalam kelompok. Dari puspa ragam masalah dan perilaku anggota kelompok, maka munculah sikap kerjasama di antara sesama anggota kelompok, seperti saling mengingatkan dan sharing permasalahan di sela-sela latihan. Menurut Setyawan (2012), sikap kerjasama dalam kelompok merupakan perpaduan dari sikap individu yang terbentuk berdasarkan komitmen bersama yang diwujudkan berupa satu sikap dan perilaku kelompok sesuai dengan karakteristik daripada sikap dan perilaku individu. Di sini, sikap kerjasama muncul sebagai pemecahan masalah terhadap kelompoknya sendiri setelah kelompok melalui berbagai lika-liku masalah.

\section{Tahap Pertunjukan Angklung}

Penyajian angklung (ujian) dari setiap kelompok dilaksanakan pada minggu kedelapan. Penyajian dikemas ke dalam bentuk pertunjukan kecil sehingga ruang pertunjukan pun (kelas) dihias dengan dekorasi sederhana sesuai dengan kemampuan dan kreativitas mahasiswa. Sehari sebelum pertunjukan, semua kelompok melakukan gladi resik, mereka belajar tata cara masuk panggung sampai keluar panggung. Hasil dari pertunjukan semua kelompok, secara keseluruhan dinilai memuaskan. Hafalan dan ekspresi angklung pun secara umum dinilai baik.

Adapun kesalahan-kesalahan yang terjadi di beberapa kelompok, disebabkan oleh kelalaian individu dalam memainkan angklung, kaitannya adalah dengan ketepatan saat untuk memainkan angklung, seperti ada yang bunyinya kurang keras sehingga mengganggu pada pemain lainnya. Namun karena komposisi angklungnya tiga suara, kesalahan seperti itu mungkin tidak akan terdeteksi oleh audiens, tapi akan terdeteksi oleh mereka yang tahu dengan pasti keseluruhan komposisi musik angklungnya, sehingga kesalahan dari individu seperti itu tidak menjadi kesalahan yang 
fatal bagi kelompoknya karena ditunjang oleh pemain lainnya yang telah hafal dengan baik terhadap tugas-tugasnya.

Ada juga satu kelompok yang memiliki kesalahan cukup fatal yang diakibatkan oleh salah seorang pemainnya yang tidak membunyikan angklung sehingga pemain lainnya ragu-ragu untuk membunyikan angklung yang menjadi tugasnya, sehingga permainan pun sempat terhenti dan diulangi lagi. Kondisi ini terjadi karena konsep permainan angklung yang saling terkait dan terbungkus dalam satu tempo permainan. Artinya, karena saling terkait, maka setiap pemain akan menunggu gilirannya setelah pemain lain membunyikannya, jadi ketika salah seorang pemain melakukan kesalahan, maka otomatis akan mengganggu pemain lainnya, seperti timbul keraguan dan keputusan akhir bisa jadi tidak membunyikan angklung.

Berikut dokumentasi pada saat pertunjukan angklung di minggu ke delapan.

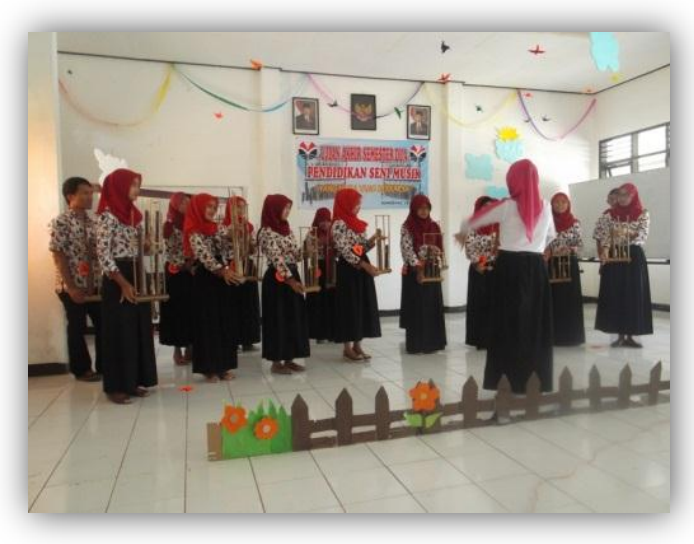

Gambar 2. Pertunjukan (UAS) Angklung Mahasiswa PGSD UPI Kampus Sumedang

\section{Kesimpulan}

Berdasarkan hasil penelitian

disimpulkan beberapa poin sebagai berikut. Pertama, pembelajaran ensemble angklung terbukti memiliki potensi untuk membangun kerjasama di antara sesama anggota kelompok, bahkan kerjasama meluas dengan kelompok lainnya. Kedua, pembelajaran ensemble angklung memaksa anggota kelompok untuk bersikap secara serius dalam menyikapi persoalan yang muncul dalam kelompoknya sebagai upaya menjaga keutuhan karya angklung (materi belajar), sehingga muncul pula problem 
solving di dalam setiap kelompok. Ketiga, pembelajaran ensemble angklung menumbuhkan pula sikap tanggungjawab, disiplin, saling menghargai, kesabaran dan kesadaran kelompok untuk berempati terhadap sesama anggota kelompok. Terakhir, pembelajaran ensemble angklung mampu menumbuhkan ikatan rasa di antara sesama anggota kelompok sebagai dampak dari pengolahan ekspresi atau dinamika dalam karya angklung. Dengan demikian, dapat disimpulkan pula bahwa dalam kerjasama kelompok, sikap individu dapat menjelma sebagai karakteristik kelompok, sehingga kesuksesan kelompok merupakan hasil kesatuan dari sikap individu beserta komitmen dan tanggung jawabnya dalam kelompok.

\section{Daftar Pustaka}

Kamusbesar: Deskripsi dari Kerja Sama. (2012, 8 Desember). Kamusbesar Online. Diambil 8 Desember 2012 dari www.kamusbesar.com 8 Desember 2012. Tersedia: http://www.kamusbesar.com/53088/kerja-sama.

Wikipedia: Pembelajaran Kooperatif. (2012, 16 Desember). Wikipedia Online. Diambil 16 Desember 2012 dari www.wikipedia.org 16 Desember 2012. Tersedia: http://id.wikipedia.org/wiki/Pembelajaran kooperatif.

Setyawan, Fendik. (2012, 16 Desember). Teori Kerjasama dan Persaingan Kelompok. [Online]. Tersedia: http://www.imadiklus.com/2012/07/teori-kerjasama-danpersaingan-kelompok.html. [16 Desember 2012]. 


\section{Bab 7}

\section{$P_{\text {enerapan nilal-Nilal kEARIFAN lokAl }}$ MELALUI PENCIPTAAN LIRIK LAGU DENGAN MENGGUNAKAN PATOKAN SEKAR IRAMA TANDAK PUPUH SUNDA}

\section{Pendahuluan}

Perubahan zaman memang suatu kondisi yang tidak bisa dihindari baik oleh masyarakat pedesaan maupun perkotaan. Sebut saja modernisasi, yang ditekankan Saud (2009:16) sebagai proses perubahan sosial dari masyarakat tradisional ke masyarakat yang lebih maju (masyarakat industri yang sudah modern), merupakan suatu keadaan yang mampu mengubah sikap dan perilaku manusia, termasuk nilai-nilai yang terkandung dalam sikap dan perilaku tersebut. Seperti hasil penelitian Amin (2002:92), yang menemukan bahwa modernisasi juga berpengaruh terhadap perilaku kehidupan masyarakat, khususnya perilaku anak. Sikap anak dalam berbicara atau sikap dalam memberikan penghormatan terhadap orang tua. Sikap anak mengalami perubahan dalam bertingkah laku, dalam bermain, dalam bergaul, dan dalam berinteraksi dengan orang lain.

Fakta di atas tentu saja perlu disikapi dengan serius, karena ini notabene berkaitan dengan perilaku yang dapat memberikan pengaruh buruk secara berkelanjutan, bahkan bisa berdampak pada perubahan tatanan nilai-nilai yang hidup dalam suatu budaya, terutama nilai-nilai yang terakumulasi sebagai kebaikan-kebaikan masyarakat setempat atau disebut pula sebagai kearifan lokal. Salah satu tatanan nilai kearifan lokal yang notabene telah tergores perubahan zaman adalah jagat seni tradisional khususnya ranah musik tradisi. Dimana musik-musik dari barat dengan mudahnya menggerayangi penggandrungnya dari mulai kawula muda hingga 
orang-orang dewasa. Sementara makna musik yang mereka tawarkan senantiasa jauh dari nilai-nilai budaya setempat, sehingga akibatnya, gaya hidup pun meniru kebarat-baratan. Padahal, seperti dikatakan oleh Kusuma (2009), tidak semua budaya barat baik dan cocok diterapkan di Indonesia. Budaya negatif yang mulai menggeser budaya asli adalah anak tidak lagi hormat kepada orang tua, kehidupan bebas remaja, dan lain-lain.

Akibatnya, antara lain anak-anak enggan belajar dan bersentuhan dengan budaya-budaya lokal, seperti belajar musik dan lagu-lagu tradisional daerah setempat. Yang tidak kalah gentingnya, para guru pendidik seni pun kurang mengondisikan dan memaksakan peserta didik untuk belajar musik tradisional, tiada lain karena kompetensi yang dimiliki dalam bidang seni budaya kurang mumpuni. Sementara itu, dalam kurikulum yang masih berlaku sekarang, kreativitas guru menjadi pilar utama dalam mengembangkan materi-materi pelajaran, khususnya dalam mata pelajaran seni budaya, sehingga jika guru tidak punya inisiatif dan kemampuan untuk mengembangkan materi-materi pelajaran, maka taruhannya adalah peserta didik bisa jadi lebih cepat beradaptasi dan mengimitasi budaya-budaya barat atau budaya populer dalam kehidupan sehari-hari melalui berbagai media ketimbang bergaul dengan budaya lokal.

Untuk menanggulangi masalah di atas, salah satu cara yang dapat dilakukan adalah menambah keterampilan calon guru atau guru seni budaya dalam menciptakan lirik-lirik lagu bermuatan kearifan lokal, karena lagu biasanya lebih cepat dicerna kandungan maknanya oleh peserta didik. Asumsinya, jika anak-anak sangat cepat memahami bahkan terpengaruh lirik-lirik lagu yang berisi tentang percintaan dua insan, maka jika diberikan lagu-lagu bermuatan kearifan lokal juga akan cepat dipahami dan terpengaruhi. Namun dikarenakan menciptakan lagu secara utuh dari sisi melodi dan lirik terlalu sulit bagi kebanyakan guru, maka solusinya dapat berupa penciptaan lirik dengan menggunakan melodi-melodi lagu yang sudah tersedia, tentunya lagu-lagu yang 
bersumber dari musik daerah setempat. Harapannya, jika guru terbiasa menciptakan lirik-lirik lagu secara kontinyu, maka tidak menutup kemungkinan pada akhirnya dapat menciptakan lirik beserta melodi lagunya.

Seperti yang telah dilakukan oleh mahasiswa jurusan Pendidikan Guru Sekolah Dasar (PGSD) Universitas Pendidikan Indonesia (UPI) Kampus Sumedang, dalam mata kuliah pendidikan seni musik mereka diarahkan untuk dapat berkreasi menciptakan lagulagu untuk anak-anak yang bersumber dari budaya daerah setempat, seperti dari aspek penggunaan tangga nada dan lirik lagunya. Kreativitas tahap awal adalah menciptakan lirik lagu dengan menggunakan aturan atau patokan salah satu jenis lagu daerah, yakni pupuh Sunda. Maka dari itu, tulisan ini berupaya untuk mengidentifikasi kreativitas mahasiswa PGSD UPI Kampus Sumedang dalam menciptakan lirik lagu yang mengandung nilainilai kearifan lokal.

Bukan berarti bahwa di daerah Sumedang atau Jawa Barat tidak ada lagu-lagu yang mengandung kearifan lokal, namun dengan menciptakan sendiri, maka lirik lagu akan lebih sesuai dengan situasi dan kondisi sosial saat ini, dan sesuai dengan keperluan serta konteks materi pelajaran yang diberikan. Dengan demikian, melalui cara ini diharapkan nilai-nilai kearifan lokal dapat tergali kembali dan dapat diimplementasikan secara langsung pada peserta didik, serta lagu-lagu pupuh Sunda dapat dilestarikan kembali secara kontinyu.

\section{Konteks Teoretis}

\section{Kearifan Lokal}

Untuk memahami kembali ihwal makna kearifan lokal, ada beberapa tulisan yang pernah membahas masalah ini, seperti Sartini (2009) yang memaparkan bahwa:

Dalam pengertian kamus, kearifan lokal (local wisdom) terdiri dari dua kata: kearifan (wisdom) dan lokal (local). 
Dalam Kamus Inggris Indonesia John M. Echols dan Hassan Syadily, local berarti setempat, sedangkan wisdom (kearifan) sama dengan kebijaksanaan. Secara umum maka local wisdom (kearifan setempat) dapat dipahami sebagai gagasangagasan setempat (local) yang bersifat bijaksana, penuh kearifan, bernilai baik, yang tertanam dan diikuti oleh anggota masyarakatnya.

Sementara itu, S. Swarsi Geriya menjelaskan, secara konseptual, kearifan lokal dan keunggulan lokal merupakan kebijaksanaan manusia yang bersandar pada filosofi nilai-nilai, etika, cara-cara dan perilaku yang melembaga secara tradisional. Kearifan lokal adalah nilai yang dianggap baik dan benar sehingga dapat bertahan dalam waktu yang lama dan bahkan melembaga (Sartini, 2009). Dari paparan tersebut dapat disimpulkan bahwa secara sederhana kearifan lokal dapat dipahami sebagai kebaikan yang berasal dan eksis dalam suatu daerah, sehingga kearifan lokal dapat berupa kearifan dalam suatu kampung, desa, kecamatan, kabupaten/kota, provinsi dan negara.

Nilai-nilai kearifan lokal yang berlaku dalam suatu daerah belum tentu sama dengan nilai kearifan lokal di daerah lainnya, namun kendatipun berbeda, kearifan lokal selalu dipandang sebagai nilainilai kebaikan yang paling sesuai dengan tempat kelahirannya dan berlaku sepanjang masa meskipun masyarakat yang hidup dalam suatu daerah silih berganti dari generasi ke generasi, termasuk nilai-nilai yang terkandung dalam seni dan budaya daerah. Maka dari itu, Cia Syamsiar (2010) menuturkan,

seni yang telah ada sejak nenek moyang mendiami bumi Indonesia, seperti seni prasejarah, seni klasik dan seni-seni tradisi serta tatanan kehidupan dalam masyarakat Indonesia yang bersumber pada nilai-nilai lokal alam lingkungan Negara kita yang telah teruji keberadaannya sebagai tatanan kehidupan masyarakat Indonesia adalah kekayaan budaya yang kita miliki yang seyogianya dirawat keberadaannya. 
Seperti layaknya melestarikan pupuh Sunda, yang notabene sebagai bagian dari kekayaan seni tradisi nusantara. Di samping itu, pupuh pun dapat dikaji sebagai seni yang di dalamnya mengandung nilai-nilai kearifan lokal.

\section{Pupuh}

Dalam Kamus Basa Sunda (KBS) karangan Satjadibrata (2005:310), dikatakan bahwa pengertian pupuh di antaranya adalah sekar, atau aturan dangding. Dalam Wikipedia (2012), dijelaskan bahwa pupuh téh nya éta wangun puisi lisan tradisional Sunda (atawa, mun di Jawa, katelah ogé macapat) nu tangtu pola (jumlah engang jeung sora) kalimahna. Begitu pula Apung Supena Wiratmadja (1996:145) menuliskan bahwa pupuh nya eta 17 rupa patokan pikeun ngadangding. Dengan demikian dapat diartikan bahwa pupuh adalah tembang yang memiliki pola kalimat yang baku, atau dapat disebut pula sebagai lagu yang memiliki aturan tertentu dalam baris-baris liriknya dengan jumlah 17 patokan sesuai dengan jumlah jenis pupuh yang ada di Jawa Barat. Aturan-aturan tersebut dipaparkan oleh Wiratmadja (1996:149) sebagai berikut.

Pupuh teh mibanda aturan-aturan anu geus tangtu:

I. Reana padalisan (jajaran)

2. Reana engang unggal padalisan, disebut guruwilangan

3. Sora panungtung unggal padalisan (boh nutup boh muka) atawa osok oge disebut dangdingdungna tungtung padalisan, disebutna gurulagu

4. Watek pupuh

Berdasarkan kutipan di atas, dapat disimpulkan bahwa aturan dalam lagu pupuh meliputi aturan dalam jumlah baris, jumlah suku kata dalam setiap baris, huruf vokal dalam suku kata terakhir dalam setiap baris, dan watak setiap pupuh.

Pupuh Sunda terdiri atas dua klasifikasi lagu dan dua jenis irama lagu. Berdasarkan klasifikasi lagu, pupuh terdiri atas: 1) sekar ageung yakni pupuh Kinanti, Sinom, Asmarandana, dan 
Dangdanggula, 2) sekar alit yaitu pupuh Balakbak, Durma, Gambuh, Gurisa, Jurudemung, Lambang, Ladrang, Magatru, Maskumambang, Mijil, Pangkur, Pucung, dan Wirangrong. Berdasarkan irama lagu, pupuh terdiri atas 1) sekar irama merdeka yakni tidak terikat pada ketukan, dan 2) sekar irama tandak yaitu terikat pada ketukan, sehingga dalam jenis ini, setiap lagu memiliki jumlah ketukan, jumlah bar, dan irama yang pasti.

\section{Metode Penelitian}

Penelitian dilaksanakan selama delapan kali pertemuan (delapan minggu) dalam mata kuliah reguler pendidikan seni musik, dengan jumlah subjek penelitian 47 mahasiswa. Pengumpulan data dilakukan dengan cara observasi langsung, karena peneliti juga bertindak sebagai pengajar (partisipant observation). Observasi tersebut bertujuan untuk menggali semua data dan mengkaji fenomena yang berkaitan dengan proses pembelajaran khususnya kreativitas mahasiswa dalam membuat lirik lagu dengan kandungan nilai-nilai kearifan, sehingga tujuan dari penelitian ini dapat tercapai sesuai dengan target yang diharapkan. Pengolahan data dilakukan setelah data-data yang diperlukan dari kelas didapatkan. Data yang diperoleh kemudian dikategorisasikan untuk selanjutnya dianalisis, dijabarkan, dimaknai dan disimpulkan.

\section{Pembahasan}

\section{Pengenalan Lagu Pupuh}

Pada umumnya, mahasiswa PGSD UPI Kampus Sumedang belum fasih dalam menyanyikan lagu pupuh, bahkan banyak di antara mereka yang sama sekali belum bisa menyanyikan lagu pupuh, apalagi hafalan terhadap lirik-lirik lagunya, didominasi oleh mahasiswa yang baru hafal satu lagu saja. Maka dari itu, pembelajaran dimulai dengan tahapan-tahapan sebagai berikut.

\section{a. Belajar ritmik}

Pembelajaran ritmik dilaksanakan selama dua kali pertemuan. Tahap ini sangat penting diberikan karena pembelajaran pupuh 
diajarkan melalui notasi. Sementara itu, mahasiswa pada umumnya tidak bisa membaca ritmik, sehingga harus dimulai dengan pembelajaran ritmik dasar. Selama dua kali pertemuan mahasiswa mampu membaca berbagai pola ritmik dengan cukup baik dari mulai not penuh sampai not $1 / 16$. Pola ritmik pun dapat dimainkan melalui permainan pola ritmik secara berkelompok baik dengan vokal saja ataupun dengan menggunakan media bunyi seperti tangan dan kaki.

\section{b. Belajar tangga nada}

Setelah selesai mempelajari ritmik, tahap selanjutnya mahasiswa mempelajari tangga nada. Jenis tangganada yang diberikan adalah fentatonis atau tangganada musik daerah yang digunakan di Jawa Barat, yaitu tangganada daminatila. Pembelajaran tangganada ini juga didasarkan pada lagu pupuh Sunda yang menggunakan tangganada daminatila. Pembelajaran dilaksanakan selama dua kali pertemuan. Materi ini diamati lebih sulit dikuasai oleh mahasiswa, karena kemampuan vokal khususnya penguasaan pitch control notabene sulit jika tidak dibiasakan sejak dini. Seperti hasil penelitian John Langstaff dan Elizabeth Mayer (1996), yang menunjukkan bahwa secara rasional pentingnya pendidikan musik pada anak sejak dini, karena pada usia 11 tahun, sirkuit neuron yang mengolah semua jenis persepsi dan diskriminasi sensori, seperti kemampuan mengidentifikasi pitch dan irama, akan tertutup. Ditambahkan pula, kalau tidak digunakan maka selamanya anak akan mengalami buta nada dan irama (Djohan, 2003:105).

\section{c. Belajar membaca lagu pupuh melalui notasi}

Pada tahap ini pada prinsipnya sama dengan tahap kedua, yaitu belajar tangganada, hanya saja, di sini tangganada yang dipelajari sudah berbentuk lagu yang bersumber dari pupuh jenis sekar irama tandak. Jadi, mahasiswa diberikan notasi lagu untuk dibaca dan dipelajari secara menyeluruh. Berdasarkan hasil pembelajaran, 
kemampuan mahasiswa terbagi ke dalam dua kategori. Pertama, mahasiswa yang mampu melantunkan pupuh dengan notasi, namun notasi dihafal sebagai lirik lagu, sehingga mereka pada dasarnya belum fasih dengan tangganada atau interval nada. Kedua, mahasiswa yang mampu melantunkan pupuh dengan notasi, dan mereka paham dengan tangganada, sehingga notasi dibaca bukan sebagai lirik lagu, namun dipahami sebagai susunan tingkatantingkatan nada. Namun dari tahapan ini, semua mahasiswa menjadi hafal bentuk dan melodi lagu pupuh secara utuh.

\section{d. Belajar menerapkan lirik ke dalam melodi lagu}

Pada tahap ini mahasiswa belajar melantunkan lagu pupuh dengan menggunakan lirik yang sudah ada. Proses singkronisasi antara lirik dan melodi lebih cepat dari tahapan sebelumnya, karena mereka tinggal mengganti saja lirik yang pada awalnya menggunakan notasi dengan lirik lagu yang sebenarnya. Jadi, tugas mereka tinggal menghafal lirik lagu pupuh yang diberikan.

\section{Penciptaan Lirik}

Tahap inilah yang menentukan tingkat kreativitas mahasiswa, dan di sini pula tujuan utama dari pembelajaran ini berada, yakni mahasiswa mampu membuat lirik lagu dengan kandungan nilainilai kearifan lokal. Tema lagu pun diarahkan supaya sesuai untuk anak-anak sekolah dasar, dan mengandung nilai-nilai moral atau nilai-nilai kearifan yang berlaku di daerah asal mereka. Lirik yang dibuat mengacu pada patokan sekar irama tandak lagu pupuh Maskumambang. Berikut lagu pupuh yang menjadi patokan tersebut. 


\section{Maskumambang}

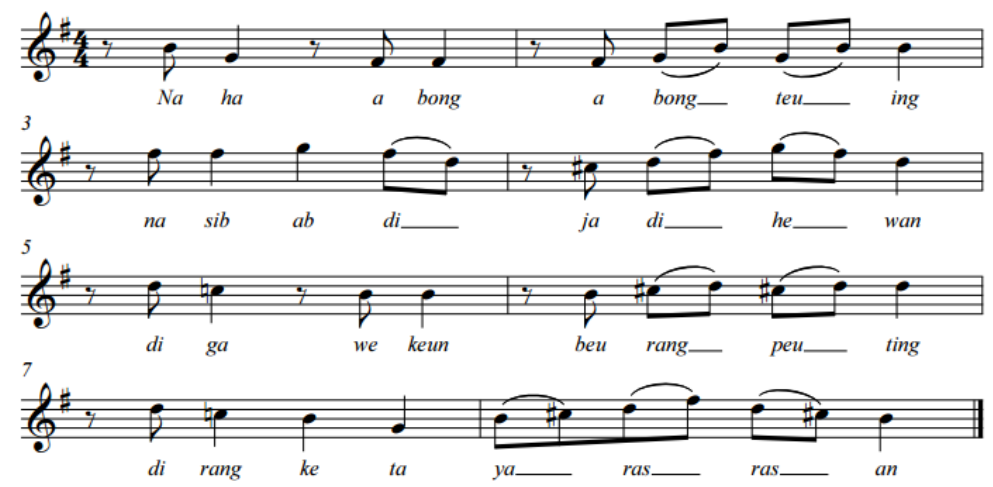

Yang dijadikan patokan dalam pembuatan lirik adalah melodi lagu, jumlah bar dan jumlah suku kata dalam setiap baris, sehingga mahasiswa diharuskan membuat lirik dengan jumlah minimal empat baris, dan setiap baris memiliki delapan suku kata, sementara bahasa yang digunakan adalah bahasa daerah mereka masing-masing. Adapun mahasiswa yang kurang fasih dengan bahasa daerah, maka diperbolehkan untuk membuat lirik dalam bahasa Indonesia.

Berdasarkan hasil pengamatan, pada umumnya membuat lirik bukan pekerjaan yang mudah bagi mahasiswa, karena diperlukan ketepatan dalam penggunaan kata-kata, sehingga ketika dirangkaikan terdengar lebih indah dan bermakna. Adapun beberapa mahasiswa yang kesulitan merangkai kata, mereka berkonsultasi dan meminta masukan. Secara umum, kesulitannya adalah menjaga isi lirik supaya berada dalam satu tema, tidak berpindah-pindah tema, dan memilih kata-kata atau padanan kata yang lebih sesuai dengan kaidah-kaidah lirik lagu, karena pada dasarnya membuat lirik lagu sama dengan membuat puisi.

Dari 47 mahasiswa yang diteliti, lirik lagu hasil dari kreativitas mereka terbagi ke dalam beberapa tema, yakni sebagai berikut. a) 
tema tentang ketuhanan berjumlah 13 orang $(27,65 \%)$, b) tema tentang pendidikan berjumlah lima orang (10,63\%), c) tema tentang etika berjumlah delapan orang $(17,02 \%)$, d) tema tentang keindahan alam berjumlah lima orang $(10,63 \%)$, e) tema tentang kasih sayang berjumlah delapan orang $(17,02 \%)$, f) tema tentang cinta budaya berjumlah lima orang $(10,63 \%), \mathrm{g})$ tema tentang menabung berjumlah dua orang $(4,25 \%)$, dan $h)$ tema tentang kehidupan berjumlah satu orang (2,12\%).

Berdasarkan data di atas, maka dapat diidentifikasi bahwa mahasiswa mampu membuat lirik yang memiliki kandungan nilainilai kearifan lokal, karena semua lirik mengandung makna-makna yang bersumber pada kebaikan, termasuk sumber keagamaan. Ini senada dengan pandangan Sartini (2009), yang menuturkan bahwa kearifan lokal merupakan perpaduan antara nilai-nilai suci firman Tuhan dan berbagai nilai yang ada. Dengan demikian, melalui caracara seperti ini, fungsi kearifan lokal seperti dipaparkan Mulyo (2013) untuk mengatur interaksi kegiatan masyarakat atau komunitas-nya, memperlakukan Alam sekitarnya, termasuk pola pergaulan yang arif dan bijaksana, dapat tercapai dengan baik.

\section{Penyajian Lagu dan Lirik}

Tahap terakhir dari pembelajaran adalah semua mahasiswa menyajikan lagu pupuh dengan menggunakan lirik asli dan lirik hasil karya cipta mereka sendiri. Tujuannya agar mereka mampu memahami lebih dalam makna yang terkandung dalam lirik yang mereka buat, sehingga diharapkan dapat lebih termotivasi untuk membuat karya yang lebih baik, dan dapat berkarya secara kontinyu demi menebarkan nilai-nilai kearifan lokal kepada para peserta didik, setidaknya melalui lirik-lirik lagu sederhana.

\section{Kesimpulan}

Berdasarkan hasil kajian, diperoleh beberapa simpulan sebagai berikut. Pertama, pengenalan dan penggalian kearifan lokal dapat dilakukan melalui pembelajaran lagu-lagu tradisional daerah 
setempat, khususnya pada jenis seni tradisional yang bermutu tinggi (adiluhung). Kedua, kepedulian dalam menebarkan nilai-nilai kebaikan dapat dilakukan melalui karya cipta berupa lirik lagu yang bersumber pada budaya lokal. Ketiga, tema beserta makna yang dimunculkan dalam lirik hasil karya mahasiswa antara lain dipengaruhi oleh latarbelakang budaya dan kondisi sosial mereka, sehingga ada perbedaan nilai kearifan yang berkembang dalam konsep hidup mereka, namun ada pula nilai kearifan yang pada dasarnya bersifat universal.

\section{Daftar Pustaka}

Amin, Rifqonul. (2002). Dampak Modernisasi Terhadap Perubahan Perilaku Etika Anak Kepada Orangtua. [Online]. Tersedia: http://digilib.uin-

suka.ac.id/4823/1/BAB\%201.\%20V\%2C\%20DAFTAR\%20PUSTAK A.pdf [2 Maret 2013].

Dhave, Dhanang. (2012). Kearifan Lokal Warisan Mahakarya Nenek Moyang. [Online]. Tersedia. http://sosbud.kompasiana.com/2012/10/17/kearifan-lokal-warisanmahakarya-nenek-moyang-496381.html [2 Maret 2013].

Djohan. (2003). Psikologi Musik. Yogyakarta: Buku Baik.

Kusuma, Afandi. (2009). Dampak Positif dan Dampak Negatif Globalisasi dan Modernisasi. [Online]. Tersedia: http://afand.abatasa.com/post/detail/2761/dampak-positif-dandampak-negatif--globalisasi-dan-modernisasi.html $\quad[3$ Maret 2013].

Mulyo, S. Satrio. (2013). Kearifan Lokal (Local Wisdom). [Online]. Tersedia: http://www.tanahimpian.org/dasar/148-kearifan-lokallocal-wisdom.html [4 Maret 2013].

Sartini. (2009). Menggali Kearifan Lokal Nusantara Sebuah Kajian Filsafati. [Online]. Tersedia: http://dgi-indonesia.com/wpcontent/uploads/2009/02/menggalikearifanlokalnusantaral.pdf [2 Maret 2013].

Satjadibrata, R. (2005). Kamus Basa Sunda. Bandung: Kiblat. 
Julia

Saud, Udin. S. (2009). Inovasi Pendidikan. Bandung: Alfabeta.

Syamsiar, Cia. (2010). Bentuk-Bentuk Kearifan Lokal dalam Kehidupan Masyarakat Indonesia Sebagai Sumber Gagasan Berkarya Seni Rupa. [Online]. Tersedia: http://jurnal.isiska.ac.id/index.php/brikolase/article/view/414 [3 Maret 2013].

Wikipedia. (2012).

Pupuh.

Tersedia:

http://su.wikipedia.org/wiki/Pupuh [3 Maret 2013].

Wiratmadja, A. Supena. (1996). Kuring jeung Tembang Sunda:

Pamanggih \& Papanggihan. Bandung: Citra Mustika. 


\section{Bale 8}

\section{$\mathcal{P}_{\text {endidikan Musik di Sekolah Dasar }}$}

\section{(Menuju Implementasi Kurikulum 2013)}

\section{Pendahuluan}

\section{Realitas Guru Musik di Sekolah Dasar}

Kita mulai perbincangan ini dengan melihat sekilas kondisi guru musik di sekolah dasar melalui beberapa pertanyaan berikut. Pertama, siapakah guru musik di sekolah dasar? Mereka pada umumnya adalah para guru yang secara formal ditempa untuk menjadi guru dalam berbagai bidang studi (seperti: IPA, IPS, Matematika, Bahasa, dan Seni), sehingga pada dasarnya guru yang mengajar musik di sekolah dasar itu belumlah secara sempurna dapat dikatakan sebagai guru musik.

Kedua, bagaimana kompetensi guru musik di sekolah dasar? Hanya sedikit kalangan guru musik yang memiliki kompetensi bagus dalam musik, yakni mereka yang sedikitnya menguasai unsur-unsur dasar musik yang tercermin dalam aktivitas musikal seperti bernyanyi atau memainkan alat-alat musik. ltu pun ratarata bukan dari hasil belajar di lembaga pendidikan formal, namun karena secara kebetulan mereka terlahir dari keluarga seniman, atau karena sebelum menjadi guru pun mereka telah terjun ke dunia seni seperti menjadi pemain band di sekolah atau pemain seni tradisi lokal, atau ada juga yang sekedar belajar musik secara otodidak dari teman sepergaulannya, seperti belajar gitar yang secara otomatis menuntut pula belajar lagu-lagunya.

Bahkan sebelum terjun ke dunia nyata pun (sekolah dasar), kemampuan calon guru-guru musik sudah dapat diidentifikasi. Seperti hasil pengamatan saya terhadap mahasiswa PGSD di Universitas Pendidikan Indonesia Kampus Sumedang sejak tahun 
2009 sampai sekarang (2014), bahwa pada umumnya kemampuan musikal mereka adalah: 1) tidak dapat bernyayi dengan pitch nada yang baik, dan jika bernyanyi di kelas, terdengar lumayan bagus jika bernyanyi secara berjamaah, dan ternyata kacau-balau jika dilakukan secara mandiri (Julia, 2013), 2) tidak dapat memainkan alat musik apalagi beragam alat musik, 3) tidak memahami wawasan musik lokal apalagi musik luar, dan 4) kebanyakan hanya menjadi pendengar setia daripada menjadi aktor utama (bernyanyi dan bermain alat musik).

Maka dari itu, apa yang terjadi di lapangan, izinkan saya untuk memberikan gambaran singkatnya berdasarkan hasil pengalaman. Satu kesempatan di tahun lalu saya berangkat untuk melakukan monitoring mahasiswa yang sedang praktek mengajar di satu sekolah dasar di kabupaten Sumedang. Kebetulan, pada saat yang bersamaan, di sekolah yang saya kunjungi ada siswa yang sedang melakukan latihan lagu daerah dengan didampingi oleh guru pembimbingnya yang kelihatannya ditugasi untuk melatih siswa tadi untuk kegiatan lomba nyanyi antar siswa/i sekolah dasar di kabupaten Sumedang. Karena berada dalam satu ruangan, maka saya pun penasaran dan memerhatikan cara guru tersebut melatih vokal. Dari hasil pengamatan, yang dilakukan guru tersebut adalah membunyikan audio kaset, kemudian menyuruh siswa untuk mendengarkan lagu dan menirukannya. Kegiatan tersebut dilakukan berulang-ulang sampai siswa dipandang telah hafal semua bagian lagunya. Dan latihan pun selesai.

Melihat peristiwa ini, akhirnya saya bertanya kepada guru tersebut, mengapa cara mengajarnya seperti itu, tidak ada pencontohan secara langsung dari guru, bahkan tidak ada evaluasi terhadap lagu yang ditiru oleh siswa tadi? Guru tersebut menjawab, bahwa ia sebenarnya tidak bisa bernyanyi, apalagi mengajarkan lagu. Jadi, yang bisa dilakukan hanya sebatas menemani siswa untuk belajar secara mandiri melalui metode mendengarkan lagu secara berulang-ulang melalui audio kaset. 
Gambaran satu guru ini kurang-lebih sama untuk mayoritas guru di kabupaten Sumedang. Bahkan lebih jauh saya tanyakan, bagaimana supaya bisa menang dalam perlombaan tersebut? Guru pun menjawab, bahwa anak yang biasa menang itu adalah mereka yang sudah memiliki kemampuan bernyanyi karena berasal dari keluarga seniman, atau biasa mengundang pelatih (seniman) dari luar untuk mengajar khusus pada saat ada kegiatan lomba. Dan ternyata, opsi kedua inilah yang paling banyak dilakukan oleh pihak sekolah, sehingga kemenangan dalam lomba pun sangat ditentukan oleh bibit siswa/i dan kualitas pelatihnya, bukan guru musik di sekolah.

Melalui gambaran ini, bukan berarti bahwa pendidikan seni itu bertujuan untuk membentuk pola kesenimanan, namun yang perlu lebih jauh disoroti adalah kompetensi guru musik beserta metode yang digunakannya dalam mengajar musik, karena di sinilah tergambar dengan jelas maksud dan tujuan pendidikan musik. Jika dari satu murid saja ternyata seperti disebutkan di atas dalam caracara pembelajarannya, lantas bagaimana dengan nasib pengalaman musikal pada siswa/i lainnya? Apa yang mereka dapatkan selama sekolah? Dan kemampuan musikal apa yang meningkat?

\section{Potensi Musik pada Anak Sekolah Dasar}

Sementara itu perlu dilihat lebih jauh, bahwa potensi siswa/i untuk mengembangkan kemampuan musikal pada jenjang sekolah dasar itu begitu besar, bahkan saat-saat itu mereka memerlukan arahan yang tepat supaya kemampuan musikal mereka benar-benar meningkat. Shuter-Dyson dan Gabriel (Hargreaves, 1986:61) membuat ringkasan mengenai perkembangan musikal pada anak, dimana langkah-langkah perkembangan musikal tersebut di antaranya:

\begin{tabular}{l|l} 
Usia & Kemampuan \\
\hline Umur 0-1: & Bereaksi terhadap suara. \\
Umur 1-2: & Membuat musik yang spontan.
\end{tabular}


Umur 2-3: $\quad$ Mulai untuk menghasilkan frase dari lagu yang didengar.

Umur 3-4: Mengatur melodi.

Umur 4-5: $\quad$ Dapat membedakan wilayah nada \& mengiramakan kembali ritme sederhana.

Umur 5-6: Mengerti keras lembutnya suara; dapat mengenali kemiripan nada atau ritme.

Umur 6-7: $\quad$ Berimprovisasi menyanyi.

Umur 7-8: Mengenali perbedaan konsonan dan disonan.

Umur 8-9: $\quad$ Perkembangan dalam mempertunjukkan ritme.

Umur 9-10: Berkembangnya dalam mengingat melodi dan mengenali kadens.

Umur 10-11: Dapat merasakan harmonik.

Umur 12-17: Meningkatnya apresiasi secara kognitif dan respon emosional.

Sumber: diadaptasi dari Hargreaves (1986:61).

Melalui paparan Gabriel di atas, dapat diidentifikasi bahwa pada usia sekolah dasar, yakni sekitar 6-12 tahun perkembangan kemampuan musikal anak relatif banyak, sehingga dengan berpatokan pada paparan di atas, guru memiliki kesempatan untuk melakukan pengembangan pembelajaran musik di kelas dengan berbagai metode, media dan lain-lain. Jadi, bukan hanya keterampilan bernyanyi saja yang perlu dikembangkan, namun semua unsur-unsur dasar musik seperti melodi, ritmik, dinamika, tempo dan irama. Yang tentu saja sangat memerlukan sisi kreatif dari guru musik agar pembelajaran dapat dilakukan secara komprehensif namun menyenangkan bagi anak.

Jika melihat hasil pembelajaran yang telah dilakukan sesuai dengan konteks kelokalan kita, ada beberapa contoh kasus yang dapat dijadikan sebagai acuan untuk melakukan pengembangan pada pembelajaran musik di sekolah dasar. Sebagai contohnya:

1. Dalam memainkan instrumen gamelan Sunda, siswa/i sekolah dasar dapat memainkan pola-pola sederhana namun dari sisi 
teknik hanya baru bisa mengatur satu tangan saja. Seharusnya dua tangan berfungsi terutama untuk gamelan jenis wilahan, tangan kanan untuk menabuh dan tangan kiri untuk menengkep agar bunyi tidak bercampur/bising, namun mereka belum bisa melakukan tengkepan karena ini memerlukan pemecahan fokus antara apa yang dikerjakan oleh tangan kanan dan tangan kiri, dan ini sudah masuk pada keterampilan tingkat tinggi. Sehingga yang biasa terjadi adalah tangan kanan menabuh gamelan dan tangan kiri bebas berkeliaran.

2. Pada saat menyanyikan lagu, rata-rata siswa/i sekolah dasar mampu mengikuti ritmik dan melodi dengan tonalitas tinggi, namun sepanjang pengamatan saya, selalu saja dalam satu kelas itu ada anak yang tidak mampu membawakan melodi dengan tepat (masalah pitch control), bahkan untuk lagu-lagu yang berbentuk paduan suara, jika dibagi ke dalam dua suara, terkadang semuanya menjadi suara satu atau semuanya menjadi suara dua.

3. Untuk permainan perkusi, banyak ketertarikan khususnya bagi anak laki-laki. Di sini mereka dapat belajar ritmik lebih jauh karena perkusi adalah alat non melodis, sehingga kepekaan ritmis pun dapat meningkat. Proses pembelajaran lebih cepat dan tepat dengan metode tutur dan menghafal, karena kepekaan musikalnya lebih terasah.

\section{Tipe Guru Musik di Sekolah Dasar}

Selanjutnya, mari kita cermati, melalui pengamatan terhadap beberapa sekolah dasar, sekurang-kurangnya ada tiga tipe guru musik di sekolah dasar berdasarkan tingkat keterampilannya dalam bermusik dan kemampuannya dalam mengajarkan materi musik.

Tipe Kesatu: Guru yang tidak memiliki keterampilan musik, namun bertugas mengajarkan musik di sekolahnya, sehingga yang dilakukannya di kelas adalah menyuruh siswanya untuk bernyanyi, menyanyikan lagu-lagu yang telah ada, atau siswa disuruh 
mendengarkan nyanyian dari kaset/CD kemudian menirukannya sesuai kemampuan masing-masing siswa.

Tipe Kedua: Guru yang memiliki keterampilan musik, dan pada saat mengajar senang dengan menjelaskan teori-teori musik, atau mempertontonkan berbagai karya-karya musik atau pertunjukan musik. Siswa sangat senang dengan pelajaran ini karena tontonannya banyak yang menarik, hampir setiap pertemuan dihabiskan dengan nonton pertunjukan.

Tipe Ketiga: Guru yang memiliki keterampilan musik, jika mengajar senantiasa mengarahkan siswanya untuk langsung praktek bernyanyi, dan juga memainkan alat-alat musik seadanya dan sebisanya, sekali-kali juga membawa siswanya untuk menonton pertunjukan musik.

Berdasarkan tiga tipe guru musik di atas, apabila kita analisis berdasarkan kebutuhan musikal anak, maka:

1. Tipe pertama lumayan memberikan pengalaman musikal pada anak, namun tidak jelas arahnya kemana, karena di sana tidak terjadi pengembangan pembelajaran, bahkan sama sekali tidak akan terjadi evaluasi yang begitu berarti, karena gurunya sendiri tidak tahu proses musikal apa yang sedang terjadi pada siswanya.

2. Tipe kedua sama sekali tidak memberikan pengalaman musikal, karena anak hanya menjadi penonton tidak menjadi pelaku utama, sementara menonton itu pada dasarnya adalah kegiatan pasif dimana di sana tidak terjadi proses pengembangan kemampuan dan kreativitas. Meskipun menonton yang merupakan kegiatan apresiasi musik itu juga penting dilakukan, namun prioritas utama adalah anak harus mengalami terlebih dahulu peristiwa-peristiwa musikal. 
3. Tipe ketiga sangat memberikan pengalaman musikal pada anak, dimana anak dibawa untuk langsung bernyanyi dan bermain alat musik, bahkan ada nilai tambahnya yaitu diselingi dengan apresiasi pertunjukan. Di sini bisa terjadi pengembangan pembelajaran, karena tidak memaksakan pengadaan alat musik yang ideal, namun bisa dengan alat-alat seadanya yang bisa menghasilkan bunyi-bunyian. Jadi, banyak pengalaman musikal yang bisa diperoleh anak dengan proses belajar seperti ini.

\section{Kebutuhan Pendidikan Musik dalam Kurikulum 2013}

Kita akan meninjau mata pelajaran SBdP dengan mengambil beberapa contoh tema dan kompetensi dasar dari kelas empat (4) sekolah dasar dalam kurikulum 2013 yaitu sebagai berikut:

1. Tema: Indahnya Kebersamaan

\begin{tabular}{|l|ll|}
\hline \multicolumn{1}{|c|}{$\begin{array}{c}\text { Mata Pelajaran dan } \\
\text { Kompetensi Dasar }\end{array}$} & \multicolumn{1}{c|}{ lndikator } \\
\hline $\begin{array}{l}\text { Menyanyikan lagu dengan } \\
\text { gerak tangan dan badan sesuai } \\
\text { dengan tinggi rendah nada (K1 } \\
4)\end{array}$ & $\bullet$ & $\begin{array}{l}\text { Menganyikan lagu anak-anak } \\
\text { sesuai tinggi rendah nada }\end{array}$ \\
\hline
\end{tabular}

2. Tema: Selalu Berhemat Energi

\begin{tabular}{|l|ll|}
\hline \multicolumn{1}{|c|}{$\begin{array}{c}\text { Mata Pelajaran dan } \\
\text { Kompetensi Dasar }\end{array}$} & \multicolumn{1}{c|}{ Indikator } \\
\hline $\begin{array}{l}\text { Berani mengekspresikan diri } \\
\text { dalam berkarya, bernyanyi, dan } \\
\text { menari (K1 2) }\end{array}$ & $\bullet \begin{array}{l}\text { Menunjukkan rasa percaya diri } \\
\text { untuk berkarya }\end{array}$ \\
& $\begin{array}{l}\text { Menunjukkan keberanian } \\
\text { mencoba untuk berkarya sesuai } \\
\text { tema "Hemat Energi" } \\
\text { Menunjukan kebebasan dalam } \\
\text { berkarya }\end{array}$ \\
\hline
\end{tabular}

3. Tema: Menghargai Jasa Pahlawan

\begin{tabular}{|c|c|}
\hline $\begin{array}{c}\text { Mata Pelajaran dan } \\
\text { Kompetensi Dasar }\end{array}$ & Indikator \\
\hline Menyanyikan solmisasi lagu & $\bullet \quad$ Menyanyikan solmisasi lagu \\
\hline
\end{tabular}




\begin{tabular}{|l|l|}
\hline $\begin{array}{l}\text { wajib dan lagu daerah yang } \\
\text { dikenal (K1 4) }\end{array}$ & $\begin{array}{l}\text { wajib } \\
\text { Menyanyikan solmisasi lagu lagu } \\
\text { daerah }\end{array}$ \\
\hline
\end{tabular}

4. Tema: Cita-citaku

\begin{tabular}{|l|ll|}
\hline \multicolumn{1}{|c|}{$\begin{array}{c}\text { Mata Pelajaran dan } \\
\text { Kompetensi Dasar }\end{array}$} & \multicolumn{1}{c|}{ lndikator } \\
\hline $\begin{array}{l}\text { Memainkan alat musik melodis } \\
\text { lagu yang telah dikenal sesuai } \\
\text { dengan isi lagu (K1 4) }\end{array}$ & $\bullet \begin{array}{l}\text { Memainkan alat musik melodis } \\
\text { lagu yang sudah dikenal }\end{array}$ \\
& $\bullet \begin{array}{l}\text { Menyanyikan lagu dengan } \\
\text { diiringi alat musik melodis }\end{array}$ \\
\hline
\end{tabular}

5. Tema: Daerah Tempat Tinggalku

\begin{tabular}{|c|c|}
\hline $\begin{array}{l}\text { Mata Pelajaran dan } \\
\text { Kompetensi Dasar }\end{array}$ & Indikator \\
\hline $\begin{array}{l}\text { Membedakan panjang-pendek } \\
\text { bunyi, tinggi- rendah nada } \\
\text { dengan gerak tangan ( } \mathrm{Kl} 3 \text { ) }\end{array}$ & $\begin{array}{ll}\text { - } & \text { Menunjukkan panjang-pendek } \\
\text { bunyi dengan gerak tangan } \\
\text { - } & \text { Menunjukan tinggi- rendah } \\
\text { nada dengan geraktangan } \\
\text { - } \\
\text { Menyanyikan lagu dengan } \\
\text { mempraktekkan panjang- } \\
\text { pendek bunyi, tinggi- rendah } \\
\text { nada dengan gerak tangan }\end{array}$ \\
\hline
\end{tabular}

Berdasarkan kelima kompetensi dasar dasar di atas, dapat diidentifikasi bahwa empat tema memerlukan keterampilan bernyanyi, yaitu tema 1, 2, 3 dan 5, dan satu tema membutuhkan keterampilan dalam memainkan alat musik melodis. Apabila kita jabarkan lagi ke dalam kompetensi-kompetensi musik secara lebih spesifik, maka dari setiap tema dapat dipaparkan sebagai berikut.

Pada tema 1, keterampilan musik yang dibutuhkan yaitu:

1. Membunyikan melodi atau nada-nada dengan tepat melalui vokal/suara.

2. Memahami dan mampu mendeteksi tinggi dan rendah nada dalam lagu.

3. Mampu menyajikan pola-pola ritmik sesuai kebutuhan lagu. 
4. Mampu melakukan gerak beraturan (kompetensi tari/gerak) pada saat bernyayi.

Pada tema 2, keterampilan musik yang dibutuhkan yaitu:

1. Membunyikan melodi atau nada-nada dengan tepat melalui vokal/suara.

2. Mampu menyajikan pola-pola ritmik sesuai kebutuhan lagu.

3. Mampu membuat lirik lagu.

4. Mampu membuat frase-frase atau kalimat melodi.

Pada tema 3, keterampilan musik yang dibutuhkan yaitu:

1. Membunyikan melodi atau nada-nada dengan tepat melalui vokal/suara.

2. Mampu menyajikan pola-pola ritmik sesuai kebutuhan lagu.

3. Mampu membunyikan tonalitas barat dan tonalitas daerah setempat.

4. Hapal lagu-lagu (lirik dan melodi) kebangsaan dan lagu-lagu daerah.

Pada tema 4, keterampilan musik yang dibutuhkan yaitu:

1. Mampu memainkan alat musik setidaknya satu alat musik melodis.

2. Memiliki keterampilan membaca notasi.

3. Hapal melodi lagu-lagu sederhana.

Pada tema 5, keterampilan musik yang dibutuhkan yaitu:

1. Mampu membunyikan tonalitas barat dan tonalitas daerah setempat.

2. Memahami interval nada.

3. Mampu membunyikan nada-nada atau melodi dengan benar.

Dengan demikian, berdasarkan kompetensi dasar kelas IV SD, maka pembelajaran musik yang diperlukan untuk calon guru SBdP antara lain: 
1. Tangganada

2. Memainkan pola ritmik

3. Membaca notasi

4. Komposisi musik/lagu

5. Membuat lirik lagu

6. Memainkan alat musik

\section{Alternatif Mengajar Musik di Sekolah Dasar}

Melalui pertimbangan yang didapat dari berbagai kasus pengajaran musik di sekolah dasar, maka ada beberapa alternatif pengajaran musik berdasarkan pada tingkat kompetensi gurunya, yakni sebagai berikut.

1. Untuk tipe guru yang bagus dalam bernyanyi dan memainkan alat musik

Guru tipe ini dapat secara leluasa mengajarkan berbagai nyanyian. Dan jangan lupakan berikan materi lagu baik lagu daerah maupun nasional. jika mampu, akan lebih baik apabila mengarang lagu sesuai kebutuhan anak. Guru ini pun dapat dengan leluasa mengajarkan alat musik, namun tentu saja alat musik yang sesuai dengan tingkat perkembangan anak.

2. Untuk tipe guru yang tidak bagus dalam bernyanyi dan memainkan alat musik

Jangan coba-coba mengajar vokal secara langsung melalui keterampilan bernyanyinya, karena hal ini dapat berbahaya terhadap proses audiasi anak dalam mempersepsi nada-nada ke dalam otaknya. Sebagai alternatif, vokal tetap diajarkan namun melalui bantuan media video, CD atau kaset. Biarkan anak-anak mendengar dan menirukan lagu-lagu yang nadanya 'benar' melalui media.

3. Untuk tipe guru yang bagus dalam bernyayi namun tidak bisa main alat musik 
Guru tipe ini dapat mengajarkan vokal secara leluasa kepada anak-anak, karena tidak membahayakan proses audiasi anak. Tantangannya guru mesti membuat variasi lagu yang menarik untuk anak supaya tidak membosankan. Artinya, lagu bisa membuat yang baru, atau yang sudah ada, tapi dibuat ke dalam sebuah sajian komposisi lagu yang baru dan menarik. Dan ini memerlukan keterampilan dalam komposisi musik.

4. Untuk tipe guru yang tidak bagus dalam bernyayi namun bisa main alat musik

Untuk tipe ini tidak usah mengajarkan nyanyian secara langsung, tapi gunakan juga media musik. Tapi guru ini bisa lebih leluasa mengembangkan kreativitas atau pengalaman musikal anak melalui bermain alat musik. Bisa menggunakan alat musik yang sudah ada, atau bisa juga menggunakan bahan-bahan yang tersedia di lingkungan sekitar untuk dijadikan sebagai sumber bunyi dalam membuat komposisi musik baru.

\section{Kesimpulan}

Berdasarkan paparan di atas, dapat disimpulkan bahwa saat ini kompetensi guru musik di sekolah dasar cukup memprihatinkan. Yang berdampak pada pendidikan musik pun belum berada pada jalur yang benar. Pendidikan musik baru dipandang sebatas pendidikan dalam mencetak seniman-seniman. Padahal pendidikan musik lebih mulia dari itu adalah sebagai media pendidikan 'kejiwaan', media penghalusan rasa, dan media menuju pencerdasan pikiran, sehingga perasaan dan pikiran manusia bisa bergandengan tangan dan saling mengimbangi satu sama lainnya.

Maka dari itu, seirama dengan bergulirnya kurikulum 2013 dan berubahnya SBK menjadi SBdP, dinilai relatif banyak keterampilan musikal yang diperlukan oleh guru-guru sekolah dasar. Dan pembangunan keterampilan musikal tersebut hanya bisa dicapai melalui pembelajaran musik yang benar secara berkesinambungan dari pendidikan dasar hingga pendidikan tinggi. Karena pendidikan 
musik yang hanya rata-rata dua SKS di perguruan tinggi, hanya mampu meningkatkan sebagian kecil saja dari potensi musikal yang ada pada tiap individu.

Namun demikian, tidak berarti bahwa karena keterampilan musik yang minim lantas tidak mau berbuat dan bertindak untuk memajukan pendidikan musik, karena jika demikian tentu pendidikan musik tidak akan pernah maju. Seperti disebutkan di atas, kita punya beragam strategi atau alternatif yang sedikit atau banyak insya Allah akan mampu memberikan bahkan meningkatkan pengalaman musikal pada peserta didik. Jadi, intinya adalah bergantung pada sisi kreativitas masing-masing individu.

\section{Referensi}

Hargreaves, D.). (1986). The Developmental Psychology of Music.

New York: Cambridge University Press.

Julia. (2013). Bunga Rampai Pendidikan Seni dan Potensi Kearifan Lokal. Bandung: CV. BintangWarliArtika.

Kompetensi Dasar Kurikulum 2013. (2013). Kemendikbud. 


\section{Bab 9}

\section{$\int_{\text {EBUAH REFLEKSI PENDIDIKAN MUSIK }}$}

Paparan ini merupakan hasil dari pemahaman saya terhadap tulisan Ki Hajar Dewantara, dalam tulisannya yang berjudul 'Hubungan Kesenian dengan Pendidikan'. Setelah membaca tulisan tersebut, terdapat beberapa hal yang dapat dijadikan acuan bagi dunia pendidikan khususnya bidang seni musik, karena sangat sesuai dengan kebudayaan kita. Walaupun yang dibicarakan oleh Dewantara adalah proses pengajaran kesenian di Taman Siswa tempo dulu, namun dinilai sangat relevan dengan perkembangan dunia pendidikan seni sekarang ini.

Dewantara menyebutkan bahwa kesenian merupakan satu bagian yang penting dalam hidup kebudayaan. Oleh karena itu, dalam mendidik dan mengajar anak-anak kesenian harus memiliki peranan yang istimewa. Dalam hal ini, bukan berarti anak-anak didik dijadikan seorang seniman dan seniwati, tapi bermaksud agar pengajaran kesenian dapat memberikan manfaat bagi rohani dan jasmani, serta memberi pengaruh yang baik terhadap perkembangan hidup.

Dalam kaitannya dengan perkembangan hidup, Dewantara menitikberatkan perhatiannya pada peningkatan 'intelektualisme'. Karena, hal tersebut sangat besar pengaruhnya terhadap perkembangan sikap 'individualisme' dan sikap 'kebendaan' atau 'materialisme'. Oleh karena itu, dengan adanya pendidikan kesenian diharapkan dapat membantu menanggulangi permasalahan tersebut. Selain itu, untuk melengkapi perkembangan kejiwaan manusia, tidak hanya sebatas 'intelek' atau 'pikiran' yang dibutuhkan, tapi juga meliputi 'perasaan' dan 'kemauan'.

Kalau kita perhatikan, pandangan Dewantara tersebut sangat sesuai dengan situasi dan kondisi sekarang ini. Diantaranya telah 
tertanamnya sikap 'individualis' pada masyarakat kita. Hal tersebut dapat dilihat dalam kehidupan sehari-hari, dimana banyak orangorang yang sudah tidak peduli lagi dengan sikap saling menghormati. Contohnya, tidak usah jauh-jauh, dalam kehidupan kampus kita pun masih banyak orang-orang yang memiliki sikap tersebut. Bagi orang-orang tertentu sikap tersebut masih diperhatikan, namun bagi sebagian besar lainnya hampir tidak dihiraukan lagi.

Untuk menanggulangi beberapa permasalahan $\mathrm{di}$ atas, Dewantara berpandangan bahwa kesenian yang harus dimasukkan ke dalam rencana pengajaran adalah dengan mengingat 'Azaz Trikon'. Pertama, 'Kontinu' dengan peradaban dan kebudayaan kita sendiri. Artinya kita harus konsisten sesuai dengan peradaban dan kebudayaan kita. Dalam hal ini, kita harus terus mempertahankan dan melestarikan kekayaan yang telah kita miliki, jangan sampai terabaikan apalagi sampai musnah.

Kedua, 'Konvengen' dengan adab dan kebudayaan bangsa-bangsa lain sedunia. Artinya kita harus dapat menyesuaikan dengan kebudayaan bangsa lain. Dalam hal ini, bukan berarti kita harus mengubah budaya kita, namun kita harus mengerti akan kebudayaan bangsa lain. Sehingga, kita akan terus berkembang sesuai dengan perkembangan zaman.

Ketiga, 'Konsentris' di dalam persatuan adab dan kebudayaan yang universal. Artinya, kita harus memiliki tujuan dalam menjalani kehidupan yang universal. Dalam hal ini, harus pandai menempatkan diri, maksudnya dalam persatuan mana bangsa kita merupakan anggota yang memiliki kepribadian. Karena, bangsa kita merupakan bangsa yang memiliki kebudayaan yang bernilai tinggi serta beraneka ragam isinya.

Dari paparan di atas, dapat ditarik sebuah kesimpulan bahwa pengajaran kesenian harus memiliki tujuan ke arah pembentukan manusia yang beradab dan berbudaya, serta menjunjung tinggi nilai-nilai keluhuran dan kehalusan. Oleh karena itu, konsep pendidikan harus disesuaikan dengan adab dan kebudayaan bangsa 
kita, serta harus dapat menyesuaikan diri sesuai dengan perkembangan zaman yang berdampak pada perkembangan budaya masyarakat.

Di negara Indonesia, konsep-konsep tentang pendidikan masih menjadi suatu hal yang selalu menjadi sumber permasalahan. Hal ini terjadi karena sebuah konsep sangat berpengaruh terhadap sistem pendidikan secara keseluruhan. Apabila sebuah konsep yang dibuat sesuai dengan situasi dan kondisi masyarakatnya, maka tidak menutup kemungkinan konsep tersebut akan berhasil membawa kita kepada arah kemajuan dan perkembangan. Namun, apabila tidak sesuai dengan situasi dan kondisi masyarakatnya, maka sudah barang tentu konsep tersebut akan gagal dalam membawa kita kepada kemajuan dan perkembangan.

Sebagai contoh, di Indonesia terdapat bidang studi pendidikan seni musik. Dalam realitanya, upaya untuk meningkatkan kualitas bidang studi tersebut merupakan suatu upaya yang sangat sulit. Karena, melibatkan berbagai komponen yang terlibat di dalamnya. Di antara komponen-komponen tersebut yang dapat dikatakan sebagai kunci keberhasilannya terletak pada pengajar, sistem pendidikan, dan masyarakatnya.

\section{Pengajar}

Pengajar yang lazim disebut guru merupakan salah satu faktor yang memiliki peranan sangat penting dalam meningkatkan kualitas serta menciptakan keberhasilan dalam pendidikan seni musik. Karena guru merupakan pelaku yang langsung berhadapan atau berinteraksi dengan peserta didik. Sehingga gurulah yang benar-benar mengetahui proses dalam pengajaran serta perkembangannya. Oleh karena itu, guru harus benar-benar memahami apa peranan yang dijalankannya.

Seperti yang dikemukakan oleh Gage and Berliner bahwa dalam proses interaksi belajar-mengajar guru berperan, bertugas, dan bertanggung jawab sebagai: (1) perencana (planner) yang harus mempersiapkan apa yang akan dilakukan di dalam proses belajar- 
mengajar (pre teaching problems) (Makmun, 2000:23). Dalam hal ini, guru harus sudah merencanakan apa yang akan dilakukan di dalam kelas serta menguasai bahan yang akan diberikan. Karena, tanpa perencanaan yang matang upaya ke arah peningkatan kualitas pendidikan akan sulit dilakukan. Apalagi dengan penguasaan materi ajar yang sangat minim, akan mengakibatkan kegagalan dalam meningkatkan kualitas pendidikan.

Selain itu, apabila tidak melakukan perencanaan serta tidak menguasai bahan ajar, maka gurunya sendiri akan mengalami kesulitan, karena tidak tahu harus dibawa kemana arah pengajarannya. Oleh karena itu, guru harus mengetahui dan memahami kurikulum yang ada serta berusaha untuk memiliki dan meningkatkan kompetensi diri sebagai salah satu upaya dalam rangka meningkatkan kualitas pendidikan.

Sebagai contoh, beberapa sekolah atau PT di Jawa Barat mengajarkan waditra (instrumen) Kacapi Indung dan Kacapi Siter sebagai salah satu bahan pelajarannya. Maka, guru yang mengajarkannya harus benar-benar menguasai waditra tersebut agar tidak terjadi penurunan kualitas pada materi yang terdapat dalam Kacapi tersebut. Selain itu, dengan menguasai waditra tersebut akan mendapatkan kepercayaan dari peserta didik dan masyarakat lainnya ihwal kemampuan yang dimiliki guru tersebut. Artinya, kemampuannya tidak akan diragukan lagi. Sehingga, dengan penguasaan materi tersebut akan lebih mempermudah dalam merencanakan bahan ajar yang akan diberikan di dalam kelas serta jelas tujuan dan sasaran pengajarannya.

Kemudian Gage and Berliner mengemukakan bahwa guru berperan sebagai: (2) pelaksana (organizer) yang harus menciptakan situasi, memimpin, merangsang, menggerakkan, dan mengarahkan kegiatan belajar-mengajar sesuai dengan rencana; ia bertindak sebagai sumber (resource person), konsultan kepemimpinan (leader) yang bijaksana dalam arti demokratis dan humanistik (manusiawi) selama proses berlangsung (during teaching problems) (Makmun, 2000:23). 
Dalam hal ini, sebagai seorang pelaksana yang langsung berinteraksi dengan peserta didik, guru harus memiliki metodemetode yang tepat dalam proses pengajarannya. Agar peserta didik terangsang dan termotivasi untuk melakukan kegiatan belajarmengajar sesuai dengan apa yang telah direncanakan. Karena, kesalahan dalam metode pengajaran yang digunakan akan mengakibatkan peserta didik tidak tertarik atau tidak antusias terhadap apa yang guru ajarkan. Sehingga, hal tersebut akan berakibat pada gagalnya upaya dalam peningkatan kualitas pendidikan.

Seperti pandangan Syaiful Sagala bahwa untuk mendorong keberhasilan guru dalam proses belajar-mengajar, guru seharusnya mengerti akan fungsi, dan langkah-langkah pelaksanaan metode mengajar (Sagala, 2006:201). Dengan memerhatikan pandangan tersebut, dapat berarti bahwa kegagalan guru dalam menyampaikan materi ajar tidak hanya disebabkan oleh kurangnya penguasaan terhadap bahan pengajaran, tetapi karena ia tidak tahu bagaimana cara menyampaikan materi pelajaran dengan baik dan tepat sehingga peserta didik dapat belajar dengan suasana yang menyenangkan.

Apalagi dalam pendapat Gage and Berliner di atas dikemukakan juga bahwa guru berperan sebagai konsultan kepemimpinan (leader) yang bijaksana. Dalam hal ini perlu pengetahuan lebih dalam bahwa guru tidak hanya sebatas sebagai seorang pengajar saja, tapi juga berperan sebagai orang tua siswa yang bijaksana. Artinya, guru harus bersikap layaknya orang tua kepada anaknya, memberikan solusi dan pencerahan kepada peserta didik dikala mereka mendapatkan kesulitan atau mengalami suatu permasalahan. Oleh karena itu, guru juga dapat dikatakan sebagai tempat berlindung bagi para peserta didik.

Terakhir Gage and Berliner mengemukakan bahwa guru berperan sebagai: (3) penilai (evaluator) yang harus mengumpulkan, menganalisis, menafsirkan, dan akhirnya harus memberikan pertimbangan (judgement) atas tingkat keberhasilan 
belajar-mengajar (PBM) tersebut berdasarkan kriteria yang ditetapkan baik mengenai aspek keefektivan prosesnya maupun kualifikasi produk (output)-nya (Makmun, 2000:23).

Dalam hal ini, guru harus dapat melakukan penilaian terhadap tingkat keberhasilan belajar-mengajar. Bahkan, lebih baik lagi apabila guru juga dapat melakukan penilaian terhadap proses belajar terutama strategi belajar-mengajar. Strategi belajarmengajar tersebut mencakup strategi penyampaian pengajaran dan strategi penilaian proses serta hasil belajar. Karena, dengan melakukan penilaian terhadap strategi belajar-mengajar akan lebih memudahkan untuk mengontrol berbagai hal yang dapat menyebabkan kegagalan dalam proses belajar-mengajar.

Menurut Sudjana \& Ibrahim bahwa strategi penyampaian pengajaran setiap bidang studi dinilai dari: (a) sumbangannya bagi pencapaian tujuan-tujuan pendidikan bidang studi yang bersangkutan; (b) keserasiannya dengan kondisi belajar-mengajar yang diinginkan; (c) kejelasan rumusannya; dan (d) mungkinnya dilaksanakan dalam kondisi dan alokasi waktu yang ada. Sedangkan strategi penilaian proses dan hasil belajar yang dirumuskan dalam pedoman pelaksanaan program dinilai dari segi: (a) konsistensinya dengan tujuan-tujuan yang ingin dicapai; (b) kelengkapan dan ketepatannya untuk memenuhi berbagai fungsi penilaian; (c) kejelasan rumusannya; (d) mungkinnya dilaksanakan; dan (e) penilaian bahan ajar (Sudjana \& lbrahim, 2004:224).

Ketiga pandangan Gage and Berliner di atas merupakan peranan guru dalam proses interaksi belajar-mengajar dalam bentuk formal yang dikenal sebagai pengajaran (instructional). Sedangkan secara umum, peranan guru adalah sebagai: (1) konservator (pemelihara) sistem nilai yang merupakan sumber norma kedewasaan dan inovator (pengembang) sistem nilai ilmu pengetahuan; (2) transmitor (penerus) sistem-sistem nilai tersebut kepada sasaran didik; (3) transformator (penerjemah) sistem-sistem nilai tersebut melalui penjelmaan dalam pribadinya dan perilakunya melalui proses interaksinya dengan sasaran didik; dan (4) organisator 
(penyelenggara) terciptanya proses edukatif yang dapat dipertanggungjawabkan baik secara formal (kepada pihak yang mengangkat dan menugaskannya) maupun secara moral (kepada sasaran didik, serta Tuhan Yang Menciptakannya) (Makmun, 2000:23).

Dengan memerhatikan pandangan tersebut, dapat diketahui bahwa pada dasarnya tugas seorang guru adalah sebagai pengubah perilaku (behavioral changes) peserta didik, kreator, dan pemelihara nilai-nilai dari ilmu pengetahuan. Oleh karena itu, tugas guru merupakan tugas yang sangat berat serta memerlukan eksistensi dan konsistensi yang tinggi agar semua tugasnya tersebut dapat terlaksana dengan baik.

\section{Sistem Pendidikan}

Sistem pendidikan merupakan salah satu faktor lainnya yang sangat berpengaruh terhadap peningkatan kualitas pendidikan. Karena sistem pendidikan merupakan bagaikan generator yang mengendalikan seluruh aktivitas yang terjadi dalam dunia pendidikan. Artinya, seluruh komponen yang terdapat di dalamnya harus tunduk dan patuh terhadap kebijakan sistem pendidikan tersebut. Sehingga, sistem pendidikan dapat dikatakan sebagai salah satu penyebab keberhasilan dalam rangka meningkatkan kualitas pendidikan.

Selain itu, dalam sistem pendidikan terdapat rancangan atau konsep pendidikan yang harus dijalankan oleh komponen pendidikan. Seperti kurikulum yang merupakan panutan bagi seluruh sekolah yang ada di Indonesia. Melihat realita yang terjadi sekarang, hal inilah yang selalu menjadi topik pembicaraan karena terjadinya perubahan-perubahan dalam kurikulum tersebut. Sehingga, berimbas pada seluruh aktivitas dalam dunia pendidikan seperti pada kegiatan belajar-mengajar. Hal ini terjadi karena setiap kali terjadi perubahan dalam kurikulum, dibutuhkan pemahaman dan penyesuaian agar sasaran yang diinginkan oleh kurikulum tersebut dapat tercapai dengan baik. 
Khusus untuk pendidikan seni musik, hal ini juga selalu mengundang kontroversi di kalangan ahli-ahli pendidik musik. Seperti yang dikemukakan oleh pakar komposisi dari Jerman yang menguasai karawitan Bali, Dieter Mack, ia berpandangan bahwa tujuan umum di dalam undang-undang nasional sebenarnya cukup baik. Kendala utama, yaitu kontradiksi antara jiwa dan realitas, terlihat pada pedoman inti mengenai pelaksanaan kurikulum pendidikan musik (Mack, 1996:1).

Dari pandangan tersebut, dapat diketahui bahwa adanya masalah pada realitas yang terjadi di lapangan dengan berdasarkan pada pelaksanaan kurikulum pendidikan seni. Dalam hal ini, yang menjadi masalah utamanya adalah bahwa seharusnya tujuan dan peranan pendidikan musik secara mendasar seyogiyanya sesuai dengan kepribadian bangsa Indonesia sendiri. Hal ini dapat dilihat pada sekolah-sekolah yang mengajarkan pendidikan seni, banyak guru yang mengajarkan musik Barat karena mereka beranggapan bahwa musik itu identik dengan musik Barat. Sementara itu, pemahaman mereka ihwal estetika, sejarah dan konsep-konsep musik Barat yang mereka bangga-banggakan itu tidak mencukupi, bahkan banyak yang keliru.

Dalam hal ini, Dewantara menegaskan bahwa untuk mendapatkan sistem pengajaran yang akan berfaedah bagi perikehidupan bersama, haruslah sistem itu disesuaikan dengan hidup dan penghidupan rakyat (Dewantara, 1962:3). Dengan memerhatikan pandangan tersebut, alangkah bijaksana dan mulianya apa yang dipikirkan oleh Dewantara. Pemikirannya sangat relevan dan signifikan dengan apa yang terjadi sekarang ini, dimana banyaknya masalah dalam hal kurikulum serta masalah dalam penghidupan rakyat, yaitu banyaknya rakyat yang kesulitan dalam memenuhi biaya pendidikan yang semakin tinggi.

\section{Masyarakat}

Dalam upaya meningkatkan kualitas pendidikan seni, masyarakat merupakan salah satu faktor yang juga turut mempengaruhi. 
Karena, dalam masyarakatlah banyak hal-hal yang dapat dicerap oleh peserta didik. Sehingga akan mempengaruhi terhadap perkembangan mereka khususnya dalam masalah seni. Dan, karena dalam lingkungan inilah mereka lebih banyak mendapatkan pengalaman. Masyarakat di sini dapat berarti lingkungan keluarga maupun masyarakat secara umum.

Biasanya yang menjadi kendala utama dalam lingkungan masyarakat, adalah kurangnya kesadaran mereka akan pentingnya pendidikan seni. Hal ini terjadi karena banyak masyarakat yang menilai bahwa seni itu identik dengan hal-hal yang terlarang, khususnya yang bertentangan dengan agama. Sehingga, mereka takut akan terjadi dekadensi moral pada anak-anak mereka. Munculnya pemahaman seperti itu dapat disebabkan karena mereka mengartikan seni seperti apa yang dapat mereka lihat dalam kehidupan sehari-hari pada tayangan-tayangan televisi atau media lainnya. Padahal, esensi dari pendidikan seni jauh dari apa yang mereka artikan itu.

Kemudian, masalah lainnya adalah kurangnya apresiasi tentang seni khususnya seni yang memiliki nilai-nilai luhur atau adiluhung. Kurangnya mengapresiasi terhadap seni-seni yang berkualitas tentu akan menyebabkan timbulnya pandangan yang merendahkan terhadap pendidikan seni. Karena, mereka tidak dapat menggali hal-hal atau nilai-nilai yang terkandung di dalamnya. Padahal, kalau kita mengkaji makna yang terkandung dalam seni khususnya seniseni tradisi, akan banyak menemukan hal-hal yang berkaitan dengan nilai-nilai pendidikan. Seperti makna yang terkandung dalam seni Tembang Sunda Cianjuran, banyak mengandung makna tentang hubungan manusia dengan Allah, hubungan manusia dengan manusia, dan hubungan manusia dengan alam. Sehingga, dengan mengetahui makna-makna seperti itu akan menimbulkan pemikiran tentang pentingnya memerhatikan pendidikan seni. 


\section{Menuju Peningkatan Kualitas Pendidikan Seni}

Dengan memerhatikan argument-argumen di atas, seyogiyanya seluruh komponen pendidikan memiliki sejumlah cara atau metode tersendiri untuk berusaha menyikapi permasalahan tersebut, khususnya bagi para komponen pendidikan yang selama ini kurang memberikan perhatian serta tidak memiliki kompetensi dalam profesinya sebagai tenaga pengajar dan pendidik, untuk kembali menumbuhkembangkan lagi eksistensinya sebagai guru yang profesional khususnya dalam bidang pendidikan seni.

Untuk itu, terdapat beberapa strategi yang mungkin harus kita ingat kembali sebagai berikut: Pertama, sebagai guru yang memiliki multiperan kiranya perlu untuk mengkaji kembali tugas yang dijalankannya sebagai pendidik yang merujuk pada pembinaan dan pengembangan afeksi peserta didik, pengajar yang merujuk pada pembinaan dan pengembangan pengetahuan (intelektual), dan pelatih yang merujuk pada pembinaan dan pengembangan keterampilan (psikomotor) peserta didik.

Oleh karena itu, sebagai langkah awal dari seorang pendidik diharapkan memiliki karakteristik seperti: mengharap ridha Allah, jujur dan amanah, komitmen dalam ucapan dan tindakan, adil dan egaliter, berakhlak karimah, rendah hati, berani dalam hal yang normatif, menciptakan suasana keakraban, sabar dan mengekang hawa nafsu, baik dalam tutur kata, dan tidak egois.

Sebagai seorang pengajar dapat lebih mengembangkan kembali budaya membaca dan menulis. Meskipun hal ini agak sulit untuk dibiasakan, namun tidak ada salahnya jika dimulai dari hal-hal kecil yang berhubungan dengan bidang yang kita tekuni. Sedangkan sebagai seorang pelatih, jelas memerlukan keterampilan yang dapat diakui khususnya oleh peserta didik, artinya jangan sampai keterampilannya diragukan. Lebih baik lagi jika memiliki kompetensi dalam bidang yang ditekuninya.

Kedua, pendidikan seni merupakan pendidikan dalam rangka menanamkan kehalusan dan keindahan agar menjadi manusia yang berbudi pekerti luhur serta memiliki kearifan. Oleh karena itu, 
seyogiyanya kurikulum pendidikan seni lebih memerhatikan materi yang akan diajarkan, memiliki sasaran pada pembentukan dan pengembangan emosi peserta didik. Sehingga, dapat menghasilkan peserta didik yang berkepribadian baik atau berakhlak karimah.

Ketiga, kurikulum pendidikan seni harus disesuaikan dengan adab (civilize) dan budaya (culture) masyarakatnya. Karena, dalam realitanya meskipun banyak pengajaran ihwal budaya daerah, namun belum terlihat adanya perubahan pada peserta didik. Indikasinya dapat terlihat pada minat dan kecintaan mereka pada budaya sendiri. Kebanyakan dari mereka menganggap bahwa budaya sendiri itu kuno, nora, dan ketinggalan zaman. Hal-hal seperti itulah yang harus direvitalisasi karena yang mereka anut itu bukan modernisasi, tapi westernisasi.

Keempat, memperbanyak apresiasi seni khususnya tentang seniseni tradisi kepada peserta didik dengan sasaran mereka dapat menemukan makna yang terkandung di dalamnya. Sehingga, nilainilai luhur yang mereka temukan dapat diimplementasikan dalam kehidupan sehari-hari. Dan, dengan cara seperti itu diharapkan juga mereka akan lebih mengenal serta mencintai budayanya sendiri.

Kelima, perlu diadakan kegiatan-kegiatan yang banyak menampilkan seni-seni tradisi khususnya di sekolah dengan kemasan yang menarik, agar secara tidak langsung menarik perhatian dan menumbuhkan keinginan untuk mempelajari seni tradisi pada peserta didik.

Terakhir, perlunya mengadakan dialog kebudayaan di tingkat PT, di sekolah, dan di lingkungan masyarakat dengan berkesinambungan. Hal ini dimaksudkan sebagai salah satu cara agar seni-seni tradisi dapat terus dilestarikan dan dapat diketahui perkembangannya. Dan tentu saja hal tersebut dilakukan dengan melibatkan peserta didik, orang tua, guru seni, serta para seniman atau para tokoh seniman. 
Julia

\section{Pustaka Rujukan}

Dewantara, Ki Hajar. (1962). Pendidikan. Yogyakarta: Taman-Siswa. Dewantara, Ki Hajar. (1967). Kebudayaan. Yogyakarta: TamanSiswa.

Mack, Dieter. (1996). Pendidikan Musik: Antara Harapan dan Realitas. Bandung: University Press.

Makmun, Abin Syamsuddin. (2000). Psikologi Kependidikan. Bandung: Rosdakarya.

Sagala, Syaiful. (2006). Konsep dan Makna Pembelajaran. Bandung: CV Alfabeta. 


\section{Sunder Tativan}

"Pendidikan Musik dalam Cengkeraman Kapitalisme".

Pernah disajikan dalam seminar nasional yang bertajuk: Paradigma Pendidikan Seni: Telaah Filosofis, Ideologis dan Praktis. Oktober 2013 di Unnes-Semarang.

"Strategi Pendidikan Musik: Tanamkan Kemampuan Berpikir Kritis".

Pernah disajikan dalam seminar internasional yang bertajuk: The Ist International Conference for Arts and Arts Education on Indonesia (ICAAE). Maret 2014 di UNY-Yogyakarta.

"Membangun Kerjasama Kelompok Melalui Ensemble Angklung pada Mahasiswa PGSD".

Pernah disajikan dalam seminar nasional yang bertajuk: Pengembangan Kompetensi Pendidik Untuk Mengantisipasi Persaingan Global. Februari 2013 di Unila-Lampung.

"Penerapan Nilai-Nilai Kearifan Lokal Melalui Penciptaan Lirik Lagu dengan Menggunakan Patokan Sekar Irama Tandak Pupuh Sunda". Pernah disajikan dalam seminar internasional yang bertajuk: The Diversity and Significance Values of Local Wisdom is a Source of Inspirations in the Art and Culture Learning that is Dignified in Our Educational Fields in Capitalism Amid Turmoil. Maret 2013 di UNS-Solo.

"Pendidikan Musik di Sekolah Dasar (Menuju Implementasi Kurikulum 2013)".

Pernah disajikan dalam seminar nasional yang bertajuk: Strategi Pendidikan Seni Pendidikan Dasar: Implementasi Kurikulum 2013. Mei 2014 di Unismuh-Makassar. 


\section{Sekelumit Tentang Penulis}

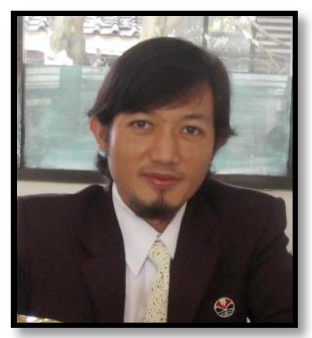

Saya lahir di Bandung dari pasangan Didi S. Winata dan Cucu H. Wiriadikarta. Merupakan alumnus SDN Cibeunying-Lembang, SMPN 2 Lembang dan SMKN 10 Bandung (dulu Kokar atau SMKI). Semasa kecil hidup di lingkungan keluarga seniman dan petani. Memperoleh gelar sarjana pendidikan seni musik (2006) dan magister pendidikan seni (2008) dari Universitas Pendidikan Indonesia (UPI). Alhamdulillah dianugrahi sebagai lulusan terbaik saat itu. Sekarang (2014) sedang melanjutkan studi S3 pada Program Studi Pendidikan Seni PPS Unnes. Penulis mengajar pada program studi pendidikan guru sekolah dasar di Universitas Pendidikan Indonesia Kampus Sumedang.

Pengalaman berkesenian selain didapat dari lembaga pendidikan formal, juga banyak diperoleh dari hasil belajar secara privat kepada seniman-seniman alam (non-akademik), khususnya tentang seni tradisional setempat.

Saya menyukai dan senang mengapresiasi puspa ragam jenis musik, namun yang paling disukai adalah musik-musik klasik, baik yang berasal dari daerah sendiri seperti Tembang Sunda Cianjuran, maupun dari tradisi luar seperti karya-karya piano klasik.

Motivasi hidup saya adalah:

"Jadikan hidup ini bermanfaat untuk banyak orang, jika tidak mampu jadikan hidup ini bermanfaat untuk keluarga, jika tidak mampu setidaknya jadikan hidup ini bermanfaat untuk diri sendiri"

Cita-cita masa kecil adalah menjadi Pilot ${ }^{\wedge} \_$

Penulis dapat disapa di:

FB

: Juli Kartawinata

Website : www.kacapi.net \& kd-sumedang.upi.edu

Email : ju82li@upi.edu

HP : 081321090866 